J Fluor Chem. 2008 September ; 129(9): 743-766. doi:10.1016/j.jfluchem.2008.06.007.

\title{
Fluorinated Nucleosides:
}

\section{Synthesis and Biological Implication}

Peng Liu, Ashoke Sharon, and Chung K. Chu

The University of Georgia, College of Pharmacy, Athens, GA 30602

\section{Introduction}

Nucleosides are structural modules of nucleic acids and therefore of fundamental importance in all living systems [1,2]. They have been playing a major role in treating tumor and virus either as selective inhibitors of certain obligatory enzymes for cancer or viral replication [3], or as nucleic acid chain terminators which interrupt the replication of cancer cells or a virus [4]. The emergence of acquired immunodeficiency syndrome (AIDS) stimulated extensive antiviral research in the past several decades. The study of anti-HIV chemotherapy has promoted a rapid progress of medicinal chemistry, molecular virology as well as an understanding of the mechanism of action of antiviral agents. Currently, about 40 compounds have been approved by the FDA for treatment of AIDS, hepatitis B and C, and infections by herpes viruses. Among the antiviral agents, nucleoside analogs have played a major role.

The selective introduction of a fluoro group into in biologically active molecules has received much attention by medicinal chemists. Several efficient synthetic methodologies for the selective formation of the C-F bond have been developed [5]. The reason for the incorporation of fluorine(s) into biologically active molecules is based on the following characteristics of fluorinated compounds: 1) Fluorine is the second smallest atom and closely mimics hydrogen without much distortion of the geometry; 2) Fluorine is the most electronegative element which can serve as an isopolar and isosteric mimic of a hydroxyl group since the C-F bond length $(1.35 \AA)$ is close to the $\mathrm{C}-\mathrm{O}$ bond length $(1.43 \AA)$, as well as fluorine is a hydrogen-bond acceptor; 3) The strength of the C-F bond exceeds that of the C-H bond which often results in increased biological and chemical stability of organofluorine compounds. Therefore, the selective introduction of fluorine atom(s) into a bioactive nucleoside as an isosteric replacement of hydrogen or as an isopolar mimic of hydroxyl group, frequently leads to a dramatic change in biological activities and becomes an important strategy in the design and discovery of novel drug candidates. Currently, there are eight fluorinated nucleoside analogs being used for the treatment of viral infections and cancer, and the additional fluoro-analogs are also undergoing in clinical trials.

In view of the progress in the medicinal chemistry of fluorinated nucleosides and the applications of newly developed methodologies in fluorination in this field, several excellent reviews on the synthetic aspects of sugar-fluorinated nucleosides have been recently published [6]. The present review deals with the synthetic methodology, structural and biological implication of carbohydrate modified fluoronuclesides.

Corresponding Author: Dr. C. K. Chu Distinguished Research Professor College of Pharmacy, The University of Georgia, Athens, GA 30602 USA e-mail: dchu@rx.uga.edu Tel.: (706) 542-5379 Fax: (706) 542-5381.

Publisher's Disclaimer: This is a PDF file of an unedited manuscript that has been accepted for publication. As a service to our customers we are providing this early version of the manuscript. The manuscript will undergo copyediting, typesetting, and review of the resulting proof before it is published in its final citable form. Please note that during the production process errors may be discovered which could affect the content, and all legal disclaimers that apply to the journal pertain. 


\section{Synthesis of carbohydrate fluorinated nucleosides}

In principle, fluorinated nucleosides can be synthesized by either fluorination of a preformed nucleoside or by the condensation of a fluorine-substituted glycone with suitable heterocyclic bases. The first approach is a linear synthetic method, which provides the original configuration of starting nucleosides, and the second approach is to condense the fluorine-containing carbohydrates with various heterocyclic bases. The second methodology can provide a variety of fluoro-nucleosides, however, the main limitation of this approach is the poor stetreoselectivity in glycosylation unless the carbohydrates possess a group at the C2-position, which can promotes the steroselectivity for glycosylation [7]. Therefore, the glycosylation reaction of a 2'-deoxy or arabinosyl sugar is, in general, cumbersome in synthetic nucleoside chemistry [8].

There are two classes of fluorinating agents (Figure 1): i) nucleophilic reagents with a fluoride ion as a donor, e.g. DAST [(diethylamino)sulfur trifluoride $\mathrm{Et}_{2} \mathrm{NSF}_{3}$; ii) electrophilic reagents, equivalents of $\mathrm{F}_{2}$ with a general structure of $\left(\mathrm{RSO}_{2}\right)_{2} \mathrm{~N}-\mathrm{F}$ or $\mathrm{R}_{3} \mathrm{~N}^{+}-\mathrm{F}$, among which selectfluor is the best representative.

\subsubsection{Nucleophilic fluorinating reagents}

Fluoride ion is the smallest anion with the largest negative charge density, so it generally acts as a hydrogen-bond acceptor rather than as a nucleophilic agent. Depending on the reaction environment, the fluoride ion can act either as a poor nucleophile (in a protic solvent) or as a good nucleophile (in polar aprotic solvents, especially with large lipophilic cations). Activation of alcohols with good leaving groups, such as mesylate, tosylate or triflate, followed by a $\mathrm{S}_{\mathrm{N}} 2$ substitution by a fluoride ion has become a standard method to replace $\mathrm{OH}$ with $\mathrm{F}$.

i) Olah's reagents: Py.nHF and ${ }^{2} \mathrm{Pr}_{2}$ NH.3HF-Secondary and tertiary alcohols can be converted to the corresponding fluorides by Olah's reagent and a preferential fluorination of tertiary alcohols over secondary hydroxyl groups is possible. Py.nHF is more acidic than ${ }^{i} \mathrm{Pr}_{2} \mathrm{NH} .3 \mathrm{HF}$, and the difference leads to their opposite regioselectivity when opening epoxides 1-1 to fluorohydrins 1-2 \& 1-3 (Scheme 1 ) and opening aziridines to $\beta$-fluoroamine [9]. The acidic HF and Py.nHF will open the epoxide ring by $\mathrm{H}^{+}$and neutralization of the secondary carbocation by $\mathrm{F}^{-}$, while in case of ${ }^{\mathrm{i}} \mathrm{Pr}_{2} \mathrm{NH} .3 \mathrm{HF}$, the epoxide is preferably attacked by $\mathrm{F}^{-}$at the least hindered carbon atom in an $\mathrm{S}_{\mathrm{N}} 2$ process.

ii) DAST ( $\mathbf{E t}_{2} \mathbf{N S F}_{3}$ )—DAST is the most versatile reagent for fluorination in nucleoside chemistry for a one-step exchange of a hydroxyl group by fluorine. It can replace primary, secondary, tertiary and allylic hydroxyl groups by fluorine in excellent yields. For most substrates, $\mathrm{S}_{\mathrm{N}} 2$ displacement of hydroxyl by fluorine occurs with a complete inversion of configuration. DAST can also convert most aldehydes and ketones to the corresponding gemdifluorides [10].

\subsubsection{Electrophilic fluorinating reagents}

When a fluorine atom binds to an electronegative nitrogen (F-X) which is activated either by strongly electron-withdrawing groups such as sulfonyl or by positive charges in the same molecule, it can act as a 'real' electrophilic $\mathrm{F}^{+}$for the addition to an electron-rich double bond or the replacement of a proton from an aromatic system (Scheme 2) [11].

As a dication, selecfluor has much higher reactivity than NFSI (Figure 1). It is a stable, easily handled, solid electrophilic fluorinating agent and soluble in polar solvents, such as $\mathrm{MeCN}$, DMF, $\mathrm{MeNO}_{2}$ and $\mathrm{H}_{2} \mathrm{O}$. Selecfluor is an equivalent of $\mathrm{F}_{2}$, but much more effective and selective. A number of fluorinations of resonance-stabilized carbanions, phosphonate, 1,3- 
dicarbonyls, enol acetates, enol silyl ethers, enamines, aromatics, double bonds and compounds containing C-S bonds have been fluorinated by selecfluor under mild conditions. Asymmetric fluorination is also achieved in the presence of various chiral catalysts [10].

In nucleoside chemistry, selecfluor is widely used to introduce a fluorine atom into heterocyclic bases via electrophilic substitution (Scheme 3).

Selecfluor can also selectively fluorinate certain sugar moieties, which possess electron-rich double bonds via an electrophilic addition (Scheme 4).

The conformation of a furanosyl moiety is believed to play a critical role with respect to the biological activity of nucleosides. The structural change caused by the replacement of oxygen or hydrogen by fluorine is significant and has been employed to promote biologically active conformations of nucleosides. In the following section, the synthetic methodology will be focused on several fluorinated nucleosides at different carbohydrate positions.

\subsection{Nucleosides fluorinated at C2'}

2.2.1 Synthesis of 2'- $\alpha$-fluoro nucleosides-The unique role of the substituent (hydroxyl or hydrogen) on the $\mathrm{C}^{2}$ '-position of nucleic acids as the distinguishing feature between deoxyribonucleic acids (DNA) and ribonucleic acids (RNA) promoted the investigation of the biological properties of nucleosides containing substituents other than hydrogen or hydroxyl groups at this position. Fox and coworkers [16] synthesized a series of 2 '-deoxy-2'-fluoro analogs of uridine, 5 -fluorouridine, thymidine and cytidine by treatment of 2,2'-anhydro nucleosides with hydrogen fluoride (Scheme 5).

This is the first example of a nucleoside with a fluorinated carbohydrate, and the $\mathrm{S}_{\mathrm{N}} 2$ reaction of a 2,2'-anhydro nucleoside by anhydrous HF became the standard method to introduce a 2'$\alpha-\mathrm{F}$ moiety into pyrimidine nucleosides [16]. Because HF itself is a hazardous reagent, the "tamed hydrofluoric acid", Olah's reagent, was used by Shi et al. [17] to fluorinate 2,2'-anhydro nucleosides (Scheme 6).

In comparison to hydrofluoric acid, Py.nHF is a milder reagent which can directly fluorinate 2,2'-anhydro-5-fluorouridine (6-1c). However, an arabinonucleoside (6-3), which can be readily prepared from $(6-1 \mathrm{c})$, can be fluorinated by DAST in excellent yield. It is noteworthy that 2'-fluoro-2'-deoxycytosine $(\mathrm{FdC})(\mathbf{6}-6 \mathbf{a})$ was found to be a potent anti-HCV agent with $\mathrm{EC}_{90}$ value of $5 \mu \mathrm{M}$, which is more potent than ribavirin, an FDA approved anti-HCV drug [18]. FdC (6-6a) also exhibits potent antiviral activity against Borna disease virus (BDV) [19].

Although the fluorination of 2,2'-anhydronucleosides is a short and direct method to introduce $2^{\prime}-\alpha-F$, the DAST fluorination of an arabinonucleoside is more versatile. $2^{\prime}-\alpha$-Fluorination of purine nucleosides [20] and 2'-branch nucleosides [21] can be achieved only by the second approach (Scheme 7). 2'-Fluoro-2'-methyl cytosine (7-14) demonstrated potent and selective inhibition of $\mathrm{HCV}$ replication with an $\mathrm{EC}_{90}$ value of $5.4 \mu \mathrm{M}$ without any toxicity up to $100 \mu \mathrm{M}[21,22]$.

Taking advantage of electrophilic NFSI, Liotta and coworkers[23] recently reported a novel 2'-afluorinating method (Scheme 8).

NFSI (Figure 1) is an air stable and easily handlable solid with a sufficient steric bulk to stereoselectively fluorinate the enolate of silyl-protected lactone (8-2) in $100 \%$ de. The $2^{\prime}-$ afluorolactone (8-3) was used as a common intermediate to synthesize a number of $2^{\prime}, 3^{\prime}$ dideoxy-2'-fluoro nucleosides [23]. 
2.2.2 Synthesis of 2'- $\beta$-fluoro nucleosides-Introduction of a fluorine atom at the 2 $\beta$-position of nucleoside analogs has produced a variety of interesting antiviral agents (Figure 2). FIAC, FEAU, FMAU and their congeners were first synthesized in Fox's group (Scheme 9 and 10) [24] and showed potent activity against HSV and also demonstrated excellent activity against hepatitis-B virus (HBV), Varicella zoster virus (VZV), cytomegalovirus (CMV), and Epstein-Barr virus (EBV). In addition, FMAU showed significant activity against murine leukemias.

F-ara-A (9-6) was first synthesized by Wright et al. (Scheme 9) [24a] as a fluoro derivative of $\beta$-D-arabinofuranosyladenine (ara-A), an agent approved by the FDA for HSV-1/2 treatment. Methyl 2,3-anhydro-5-O-benzyl- $\beta$-D-riboside (9-1) was treated with $\mathrm{KHF}_{2}$, which gave a mixture of the $3^{\prime}$ - and 2'-fluoro-D-arabinofuranoside (9-2a) and (9-2b) with the 3'- $\beta-F$ isomer as the major product. $2^{\prime}-\beta$-Fluorinated sugar (9-4) was used for coupling with 2,6dichloropurine to give nucleosides (9-5) and subsequently afforded F-ara-A (9-6). Due to the low yield of the 2-fluoro sugar (9-2b), Watanabe et al. [24b,c] subsequently developed a practical synthetic approach to 2-deoxy-2-fluoro-D-arabinose (10-6) and (10-7) from a readilyavailable D-glucose derivative (10-1, Scheme 10).

The crucial steps were the fluorination of (10-1) by KF in acetamide as well as the conversion of 6-O-benzoyl-3-deoxy-3-fluoro-D-glucofuranose (10-5) into 5-O-benzoyl-2-deoxy-2-

fluoroarabinofuranose (10-6) by periodate oxidation. A series of pyrimidine nucleosides, such as FMAU, FEAU and FIAU, were prepared in a large scale for biological evaluation (Figure 2). Unfortunately, the phase I trials of FMAU as an antileukemic agent were terminated due to neurological toxicity [25]. FIAU also exhibited delayed toxicities due to the interference of mitochondrial function resulting in lactic acidosis and hepatic failure [26].

Because of the broad spectrum of biological activities of 2'-F-arabinofuranosyl nucleosides, a number of structural modifications of these analogs have been carried out. Chu and co-workers have demonstrated that the enantiomer of FMAU, L-FMAU (Figure 2), is a promising agent against HBV [27]. It showed low toxicity in rats and woodchucks, potent in vivo antiviral activity against chronically infected woodchuck (WHV), respectable bioavailability and showed no significant virus rebound up to 36 weeks after cessation of the drug treatment. LFMAU was approved as anti-HBV drug by the Korean FDA in Nov. 2006 and is under phase III clinical trials in the USA and Europe. Another interesting congener is clofarabine which was approved by FDA for the treatment of acute lymphoblastic leukemia [28].

$4^{\prime}-$ Thio substituted 2'- $\beta$-F nucleosides also retain their antiviral activity. Machida et al. have reported that 2'-fluoro-4'-thioarabinonucleosides are active against HSV-1, HSV-2, VZV, and HCMV [29]. S-FaraG (Figure 2) and S-FaraDAP are particularly potent against all types of herpes viruses and showed a 6-fold lower $\mathrm{EC}_{50}$ value in comparison to ganciclovir against HCMV. A carbocyclic derivative of FMAU and C-FMAU also showed moderate anti-HSV-1 activity [30], whereas C-F-araA (Figure 2) is 10-fold more active than cyclaradine itself against HSV-1 and HSV-2, and is more active than acyclovir against HSV-2 in mice [31].

The potent antiviral activities of FIAC and FMAU prompted Tann et al. [32] to develop an efficient method for the construction of the $2^{\prime}-\beta-F$ arabino configuration (Scheme 11). The direct displacement of 2-imidazoylsulfonate (11-3) with $\mathrm{KHF}_{2}$ gave a $63 \%$ yield of $2^{\prime}-\beta-\mathrm{F}$ sugar (11-4), and subsequent bromination with $30 \% \mathrm{HBr}$ in HOAc produced a quantitative conversion to the 1- $\alpha$-bromo sugar (11-5). The exclusive formation of the 1- $\alpha$-glycosyl bromide (11-5), attributed to the stabilizing interaction between the unshared electron pairs on fluorine and oxygen with the $\sigma^{*}$ orbital for the axial C-Br bond, the so-called "anomeric effect" [33], leads to preferential formation of $\beta$-nucleosides, and (11-5) is being used as a standard sugar for the preparation of 2'-deoxy-2'-fluoro-arabinonucleosides, in particular for pyrimidine 
nucleosides. It is noteworthy that the condensation of bromosugar (11-5) or (10-7) with 6chloropurines is usually difficult [6,34]. In fact, the reactions of the sugar (10-7) with some purine bases, such as 6-chloropurine and 2,6-dichloropurine, gives a complicated mixture of four isomers (7-, or 9-substitued, $\alpha, \beta$ anomers) from which the desired isomer was separated in low yield [28a,35]. Starting from adenosine, after protecting the 3',5'-dihydroxyls with a bulky trityl group to make the furanose ring adopt the C-2'-endo conformation, Watanabe and coworkers[36] synthesized 2'-deoxy-2'fluoro arabinoadenosine (12-3) by TASF fluorination of the 2'-OH in 30\% yield (Scheme 12). Accordingly, Mikhailopulo et al. [37] chose a bulky pivaloyl group to protect adenosine, from which F-araA derivative (12-6) was prepared in $31 \%$ yield via DAST fluorination of the $2^{\prime}-\mathrm{OH}$.

Although the direct coupling of the bromosugar (10-7) with 2,6-dichloropurine gave an unacceptable yield [28a], Montgomery et al. [28b] synthesized and evaluated various 2-halo-9(2-deoxy-2-fluoro- $\beta$-D-arabinofuranosyl)adenines and found that clofarabine (Figure 2) possessed potent anti-tumor activity. Recently, Bauta et al. [28c] reported an efficient manufacturing process for clofarabine starting from commercially available bromosugar (11-5) (Scheme 13).

In view of the interesting discovery of L-nucleosides as biologically active compounds, the Chu's group synthesized L-FMAU and its derivatives [38,39] (Scheme 14) and evaluated these compounds as potential antiviral agents. From this effort, they discovered L-FMAU as a potent antiviral agent against $\mathrm{HBV}$ as well as Epstein-Barr virus.

2',3'-Dideoxy nucleosides (ddNs) exhibit potent anti-HIV activity and several in this class of nucleosides, such as ddI and ddC, are in clinical use. However, the instability of these compounds in an acidic media complicates oral administration. Since the fluorine at the 2 'position of a carbohydrate moiety can provide acidic and enzymatic stabilities to the glycosidic bond of nucleosides, a number of $2^{\prime}-\mathrm{F}$ ddNs have been prepared and evaluated. The $2{ }^{\prime}-\alpha-F$ isomers of ara-ddI and ara-ddA were inactive, but the 2 '- $\beta$-F isomers, F-ara-ddI and F-ara-ddA, were just as potent as parent drugs [6a].

As an efficient method to synthesize $2{ }^{\prime}-\beta-F$ ddNs, a standard sugar moiety (11-5) [40] and related 2'-deoxy-2'-fluoro arabinonucleosides (15-1) [41] were extensively used to synthesize Fara-ddNs (15-3) via Barton deoxygenation of 3'-OH (Scheme 15). 2,2'-Anhydro nucleoside (15-4) can also be used to synthesize a 2'-F-d4T analog (15-5) and 2',3'-dideoxy- $2^{\prime}, 3^{\prime}$-difluoro arabinonucleoside (15-6) [41].

The requirement for tributyltin hydride in the deoxygenation step is especially troublesome as it results in tin contamination of the final product. Therefore, some convergent methodologies, which removed the $\mathrm{C}-3$ hydroxyl group in an early stage of sugar preparation, were developed to synthesize 2 '- $\beta$-F ddNs (F-ara-ddNs).

Taking advantage of the anomeric effect of 2 '- $\beta-F$ (Scheme 11), Chu and co-workers [42] developed two practical routes to key intermediates, $1^{\prime}-\alpha-\mathrm{Br}-2^{\prime}-\beta-\mathrm{F}$ sugar moieties, (16-4) and (16-8), for the synthesis of D- and L-2',3'-dideoxy-2'-fluoro arabinonucleosides, respectively (Scheme 16). Ocabe et al. at Roche [43] also described another efficient procedure to prepare a similar sugar moiety (Scheme 17).

In fact, for the synthesis of anti-HIV agents, F-ara-ddA, F-ara-ddI and their analogs, a variety of methods were developed, such as fluorination at the $C 2^{\prime}-\beta$-position of the purine 3 'deoxynucleosides [44] and hydrogenation of 2'-F d4Ns [45].

2.2.3 Synthesis of 2',2'-difluro nucleosides-Gemcitabine (2'-deoxy-2', $2^{\prime}$ difluorocytidine) is a clinically effective anti-cancer agent for the treatment of pancreatic 
cancer. It has also shown anti-tumor activity against a wide spectrum of human solid tumors. Researchers at Lilly [46] described the synthesis of gemcitabine, which constructed the 2,2difluoro-D-ribose moietey using a $\mathrm{CF}_{2}$-containing building block (Scheme 18). Thus, glyceraldehyde (18-1) was coupled with ethyl bromodifluoroacetate under Reformatski conditions to give a 1:3 mixture of (18-2) and (18-3). The major isomer was hydrolyzed to give lactone (18-4), which was further converted to 2,2-difluoro-D-ribose (18-6). Due to the strong electron-withdrawing effect of the 2-gem-difluoro group, the intermediate (18-6) was converted to the 1-O-mesylate (18-7), which was condensed with cytosine to afford gemcitabine.

Similarly, Chu and coworkers synthesized a series of L-2',2'-difluoro ribonucleosides [47] and their $3^{\prime}$-deoxy derivatives. However, none of those showed any antiviral activity against HIV, HSV and HBV [48].

\subsubsection{Synthesis of 2'-fluoro-2',3'-didehydro-2',3'-dideoxy nucleosides (2'F-d4Ns)}

$-2^{\prime}, 3^{\prime}$-Unsaturated nucleosides, d4T and abacavir, are clinically effective anti-HIV agents and a number of $2^{\prime}$ - or $3^{\prime}$-substituted d4N analogs also retain their anti-HIV activity. In particular, introduction of a fluorine atom at the 2'-position produces compounds with anti-HIV and antiHBV activity. Chu and coworkers [49] demonstrated that a series of $2^{\prime} \mathrm{F}-\mathrm{d} 4 \mathrm{Ns}$ have interesting biological profiles and L-2'F-d4C and L-2'F-d4FC are among the most potent anti-HBV agents (Table 1),.

As shown in Scheme 19, L- and D-glyceraldehyde acetonide were subjected to HornerEmmons reaction in the presence of fluorophosphonoacetate and NaN(TMS $)_{2}$ to give 2-fluoro$\alpha, \beta$-unsaturated carboxylate (19-2) [49a] and (19-6) [49b], respectively. The esters (17-2) and (19-6) were cyclized under acidic conditions to 2 -fluorobutenolides, and then transformed to the key intermediates, acetates (19-4) and (19-8), respectively. Condensations of the sugar moieties (19-4) and (19-8) with various silylated purines and pyrimidines was carried out to furnish L- and D-2'F-d4Ns, respectively.

The synthesis of D- and L-S-2'F-d4Ns [49c,d] started from $(S)$ - and $(R)$-2-fluorobutenolide (19-7) and (19-3), respectively (Scheme 20). Lactone (19-7) was hydrogenated to give butyrolactone (20-1). The iodo ester (20-2) was generated from compound (20-1) which was transformed to thiolactone (20-3). The key intermediate (20-6), 4-thio-D-ribofuranoside, was obtained after several manipulations. The condensation of sugar (20-6) with bases gave exclusive $\beta$-nucleosides by virtue of the bulky $\alpha$-phenylselenyl group. Oxidation with mCPBA followed by pyridine catalyzed elimination afforded D-S-2'F-d4Ns.

The synthesis of D- and L-C-2'F-d4Ns is accomplished through a lengthy sequence (Scheme 21) [49e]. The Ketone (21-1), prepared from D-ribose in 17-step, was fluorinated with DAST to give a difluorinated compound (21-2), which underwent elimination in the presence of potassium tertbutoxide to an allylic ether (21-3). After debenzylation using sodium metal in liquid ammonia, the key intermediate (21-4) was obtained which was coupled with purines and pyrimidines under Mitsunobu conditions.

\subsection{Nucleosides fluorinated at C3'}

2.3.1 Mono-fluorinated at C3'-The effect of a single fluorine atom at various positions of the carbohydrate moiety in dideoxynucleosides (ddNs) as reverse transcriptase inhibitors has been investigated extensively. The structure-activity relationships for these mono-fluoro ddNs shows that a sugar moiety, a fluorine atom at positions 3'-"down" or 2'-“up" correlates well with anti-HIV activity. On the other hand, fluorine atoms at the same positions, but with inverted stereochemistry, namely 3 '- $\beta-F$ or 2 '- $\alpha-F$ configurations, generally produced inactive compounds [50]. 
A number of $3^{\prime} \alpha$-fluorinated ddNs display potent antiviral activity (Figure 3). $3^{\prime} \alpha$-Fluoro- $2^{\prime}$, $3^{\prime}$-dideoxyuridine (FddU) demonstrated anti-HIV whereas ddU is inactive, and the $3^{\prime} \alpha-F$ substitution of ddG (FLG) has higher anti-HIV activity in comparison to the parent nucleoside in MT-4 and CH3 cells [51]. FddT (FLT) is one of the most potent inhibitors of HIV RT [52]. Unfortunately, FLT produces profound toxic effects. However FddClU demonstrated significant ant-HIV activity with low cytotoxicity in human leukemic cells as well as in bone marrow progenitor cells [53a]. FddClU is also active against HIV strains resistant to AZT, ddI, ddC and 3TC [53b]. FddG and L-FddC have also demonstrated their anti-HBV activity [54, $55]$.

Two approaches are used for the synthesis of $3^{\prime} \alpha \mathrm{F}-\mathrm{ddNs}$ : (i) transformation of natural 2'deoxyribonucleosides [56] or ribonucleosides [57] to the desired dideoxyfluoro derivatives, and (ii) coupling of heterocyclic bases with suitable sugar moieties containing $3^{\prime} \alpha \mathrm{F}-$ [58] or a C3-xylo-hydroxyl group [59], which may be replaced by a fluorine atom. Natural ribonucleosides, although being the most synthetically accessible nucleosides, are less amenable for the synthesis of $3^{\prime} \alpha \mathrm{F}-\mathrm{ddNs}$, probably due to lengthy transformation procedures. However, two recently published methods are of interest, in which Robins et al. [60] developed a facile sequence with deoxygenative [1,2]-H shift rearrangement as the key step (Scheme 22). The transformation from ribonucleoside (22-2) to 2'-deoxy xylonucleoside (22-3) consists of a [1,2]-hydride shift with the departure of a leaving group from the opposite face. Transient formation of a $\mathrm{C}=\mathrm{O}$ group is followed by rapid transfer of a hydride-equivalent from the same face from which the leaving group departed, which results in a double inversion of the stereochemistry at the two vicinal carbon atoms. Thus, $3^{\prime} \alpha \mathrm{F}-\mathrm{ddNs}$ (22-6) were prepared from ribonucleoside (22-1) in 6 steps in good yield.

Takamatsu et al. [61] described another facile 6-step synthesis of $3^{\prime} \alpha \mathrm{F}-\mathrm{ddN}$ using a similar deoxygenative rearrangement which involved a [1,2]-bromo shift during $3^{\prime} \alpha$ fluorination (Scheme 23).

2.3.2. 3',3'-Difluoro and 3'-fluoro-2',3'-didehydra-2',3'-dideoxy nucleosides (3'Fd4Ns)-For the synthesis of $3^{\prime}, 3^{\prime}$-difluoronucleosides, two methods are used for a $\mathrm{CF}_{2}$ introduction: (i) difluorination of a carbonyl group $(\mathrm{C}=\mathrm{O}$ ); (ii) construction of appropriate sugar moieties with $\mathrm{CF}_{2}$-containing building blocks. The former is a direct and facile approach, but only applicable to cyclic ketone substrates with less steric hinderence (no substituent adjacent to carbonyl group). Chu and coworkers [62] developed a general synthetic method to prepare both D- and L-2',3'-dideoxy-3',3'-difluoronucleoside and their analogs (Scheme 24). Resorting to difluorination of an appropriate ketone, the key $\mathrm{CF}_{2}$-containing sugar intermediates (24-5) or (24-9) were prepared, which were subsequently condensed with bases to afford the corresponding $3^{\prime}, 3^{\prime}$-difluoronucleosides (24-10) and (24-11), respectively.

Using the same strategy, Chu and coworkers also synthesized thiosugar [63] as well as carbocyclic analogs [64] of 2',3'-dideoxy-3',3'-difluoro nucleosides (Scheme 25). None of the synthesized nucleosides showed any antiviral activity.

For the preparation of 3',3'-difluoro nucleosides bearing vicinal 2'-OH, Qing et al. [65] provided a stereoselective procedure using a $\mathrm{CF}_{2}$-containing building block (Scheme 26). The method involves a sequence that includes a coupling reaction of a gem-difluorohomoallylic metallic reagent with D-glyceraldehyde acetonide, Sharpless asymmetric dihydroxylation of the resulting homoallylic alcohol, followed by a stereoselective ring forming reaction provided both D- and L-3'-deoxy-3',3'-difluororibonucleosides (26-6) and (26-8).

Like 2'F-d4Ns (Table 1), 3'-fluoro-2',3'-unsaturated nucleosides and their 4'-thiofuranosyl analogs as well as carbocyclic analogs were synthesized via an elimination reaction of $3^{\prime}, 3^{\prime}-$ 
difluoronucleosides, which were synthesized as described in Scheme 24 and 25, in the presence of ${ }^{t} \mathrm{BuOK}$ (Scheme 27), and their antiviral activity were evaluated [62-64] (Table 2).

The complete SAR study of the synthesized 3'F-d4Ns showed that several compounds possess potent anti-HIV activity (Table 2) [62-64]; D-3'F-d4C and D-3'F-d4A show modest anti-HIV activity in $\mathrm{H} 9$ cells, whereas L-3'F-d4C, L-3'F-d4FC and their 4'-thio analogs, L-S-3'F-d4C, LS-3'F-d4FC, exhibit potent anti-HIV agents without significant toxicity. Carbocyclic D-3'F$\mathrm{d} 4 \mathrm{G}$ also exhibited potent anti-HIV activity $\left(\mathrm{EC}_{50} 0.4 \mu \mathrm{M}\right)$. In addition, D-C-3'F-d4G and L-3' $\mathrm{F}-\mathrm{d} 4 \mathrm{C}$ showed significant activity against lamivudine-resistant virus (HIV-1 $\left.{ }_{\mathrm{M} 184 \mathrm{~V}}\right)$ in PBM cells.

The 2', $3^{\prime}$-Double bond along with the fluoro group significantly enhanced the antiviral activity of the nucleosides (Table 1 and 2) [66]. Recent modeling studies (Figure 4a) [67] highlighted the additional hydrophobic interaction mediated by the $2^{\prime}, 3^{\prime}$-double bond with the active site residue (Tyr115) of HIV-1 reverse transcriptase to enhance the overall binding affinity. Further, the fluoro group at 2'-position orients the sugar moiety towards Met184 residue and reduces antiviral potency in M184V (Figure 4b) [67]. In another study, the fluoro group at the 3'position reveals a different biological profile for $\mathrm{D}$ - and L-nucleoside. The L-nucleosides such as L-S-3'F-d4C showed potent anit-HIV activity while D-S-3'F-d4C was found to be inactive. Modeling studies (Figure 5) [63] suggest the favourable binding mode of L-S-3'F-d4C in the active site without any steric hindrance with Met 184 , while the D-S-3'F-d4C displays an unfavorable overall conformation due to presence of the intramolecular interaction between 3'-F and $\beta$-phosphate.

4'-Subsituted nucleosides are believed to function as 'delayed chain terminators' [68] which arise from the rigid north-conformation of their sugar rings [69] and have a novel anti-HIV mechanism which differs from the conventional 2', 3'-dideoxy nucleosides. Ohrui et al. [70a] reported a number of 4'-ethynyl-2'-deoxy nucleosides, some of which were identified as among the most potent anti-HIV compounds which blocked the replication of a wide spectrum of laboratory and clinical HIV-1 strains. In view of this observation, Chu and coworkers [71] also synthesized D- and L-4'-ethynyl-3'-fluoro 2', 3'-unsaturated nucleosides (28-11) and (28-12) (Scheme 28).

Fluorine-containing lactone (20-1), which was prepared form D-glyceraldehyde acetonide (19-5), was converted to the $\alpha, \beta$-unsaturated ketone (28-4), the key intermediate, which was subjected to the standard Grignard reaction with ethynylmagnesium bromide to give a separable mixture of (28-5) and (28-6) in a ratio of 3:2 with a total yield of 72\%. Tertiary alcohol (28-5) and (26-6) underwent a series of reactions including the deprotection, oxidation, and acetylation to furnish the D- and L-3-fluoro-2,3-unsaturated-4-ethynylfuranose (28-9) and (28-10), respectively. D- and L-4'-Ethynyl-3'-fluoro-2', 3'-unsaturated nucleosides were thus synthesized from (28-9) and (28-10). Unfortunately, none of these nucleosides showed any potent anti-HIV activity.

\subsection{Nucleosides fluorinated at C4'}

Although natural nucleocidin (Scheme 29) was isolated in 1957, 4'-substituted nucleosides was not identified as a new class of anti-HIV nucleosides until Maag et al. [72] found that 4'azido-2'-deoxythymidine (4'AZT) exerted potent activity against HIV-1 in 1992. Extensive structure-activity studies found that other substituents, such as methyl, fluoromethyl, ethynyl and cyano at 4'-position also exhibited high antiviral activity against HIV [73]. The unique anti-HIV activity of these nucleosides may be due to the rigid north-conformation of their sugar rings which related to $4^{\prime}$-substitution. 
As shown in Scheme 29, Moffat et al. [74] developed a method for the introduction of fluorine atom at the C4'-position from 4',5'-dehydronucleoside (29-2). Thus, the $4^{\prime}, 5^{\prime}$-olefin (29-2) was subjected to electrophilic addition of iodine fluoride which gave a mixture of 4'- and 5'fluorinated nucleosides unselectively. The desired 4'-fuoro-5'-iodo nucleoside (29-3) is the key intermediate for nucleocidin. The $4{ }^{\prime}, 5^{\prime}$-dehydronucleoside can also be converted to the $4^{\prime}-\beta$ OH intermediate (29-4), followed by selective introduction of the $4^{\prime}-\alpha-\mathrm{F}$ by fluorination with DAST. Hong et al. [75] reported the synthesis of a chiral fluorine-containing building block (30-3), which was utilized in the convergent synthesis of 4 '-fluorinated apionucleosides (30-6) [75] and carbocyclic 2',3'-didexoy nucleosides (30-12) [76] (Scheme 30).

\subsection{Nucleosides fluorinated at other positions}

2.5.1. C6'-fluorinated carbocyclic nucleosides-Carbocyclic nucleosides are quite unique and as a result it is difficult to identify biologically active agents with respect to their furanose counterparts [77], probably due to their different conformational factors of the carbocyclic ring. The way to make the conformation of the carbocyclic ring similar to their furanose equivalents would be to put electronegative substituent(s) such as a fluorine atom into the ring. The $\mathrm{CF}_{2}$ group has been suggested by Blackburn [78] as an isopolar and isoteric subsituent for oxygen. Thus Qing and coworkers [79] synthesized 6',6'-difluoro d4U (Scheme 31). The key intermediate, gem-difluorinated 2,3-unsaturated cyclopentyl alcohol (31-5), was prepared from (Z)-but-2-ene-1,4-diol via ring-closing metathesis, and the introduction of gem-difluoromethylene group was accomplished by a silicon-induced Reformatskii-Claisen reaction of chlorodifluoroacetic ester (31-1).

$\alpha$-Fluorination of the cyclopentanone derivative with Selecfluor is another way to synthesize 6 '-fluoro carbocyclic nucleosides. Samuelsson et al. [80] described an asymmetric synthesis of 6'- $\alpha$ - and 6'- $\beta$-monofluorinated carbanucleosides (Scheme 32). Thus, silylenol ether (32-2) which was prepared from cyclopentanone was treated with Selecfluor in DMF to give 1:1 inseparable mixture of the fluoroketones (32-3) and (32-4). Selective reduction of the ketone gave two diastereomeric alcohols, the key intermediate (32-5) and (32-6) for 6'fluoronucleosides, in $41 \%$ and $49 \%$, respectively.

2.5.2. Nucleosides bearing exocyclic fluorocarbon substituents-The influence of a trifluoromethyl group in biologically active molecules is often associated with its increased lipophilicity. In addition, its electronegativity (similar to fluorine) and the size (in between methyl and isoppropyl) are also contributing factors. The unique nature of the fluoromethyl group has prompted interest in the synthesis of nucleosides bearing exocyclic fluorocarbon substituents.

Several methods have been described in the literature for introducing a $\mathrm{CF}_{3}$ group into nucleoside analogs [81]. However, the utilization of Ruppert's reagent, (trfluoromethyl) trimethylsilane $\left(\mathrm{TMSCF}_{3}\right)$, as a nucleophilic trifluoromethylating reagent is rapidly becoming the method of choice. Such methodology requires the previous preparation of a suitable 2- or 3-keto sugar intermediate, which then accept the nucleophilic attack of $\mathrm{CF}_{3}$ carbanion. 3'Trifluoromethyl nucleosides were reported [82] (Scheme 33) via this method. The Barton-type deoxygenation of the unreactive tertiary hydroxyl function using imidazole-1-thiocarbonyl or the phenoxythiocarbonyl derivative was unsuccessful. However, with a modification of the radical deoxygenation using the methyloxalyl ester derivative, the tertiary hydroxyl group (33-2) underwent stereospecific deoxygenation wherein the hydrogen atom abstraction from $\mathrm{Bu}_{3} \mathrm{SnH}$ occurred from the $\beta$-face to give 3-trifluoromethylated sugar (33-3) in good yield. Similarly, $\mathrm{a} \mathrm{CF}_{3}$ group can be introduced at the $\mathrm{C} 2$ position of a sugar to prepare 2 'trifluoromethylated nucleosides [83]. 
The carbonyl group in the sugar unit can also be utilized to introduce a difluoromethyl group via a Wittig-type reaction or a nucleophilic addition with a $\mathrm{CF}_{2}$-containing reagent.

Serafinowski et al. [84] treated 2'-oxo (or 3'-oxo) nucleosides with bromodifluoro[tris (dimethylamino)] phosphonium bromide and zinc to afford the corresponding 2'- (or 3'-) difluoromethylene nucleosides (Scheme 34). The difluoromethylene function of (34-5) can be transformed to a difluoromethyl group by hydrogenation or by TBAF mediated rearrangement.

Besides the above-mentioned Wittig-type olefination with the reagent generated in situ from $\mathrm{CF}_{2} \mathrm{Br}_{2} /\left(\mathrm{Me}_{2} \mathrm{~N}\right)_{3} \mathrm{P}, \mathrm{McC}$ arthy et al. [85] reported a modified Julia's approach to introduce a difluoromethylene function at the 2 -keto position (Scheme 35). The $\alpha$-face addition of the carbanion of difluoromethyl phenyl sulfone, $\mathrm{PhSO}_{2} \mathrm{CF}_{2} \mathrm{H}$, into the protected 2-keto nucleoside (35-1) gave a sulfone (35-2) in $85 \%$ yield. The subsequent reductive elimination of tertiary mesylate (35-4), prepared from (35-2) in $70 \%$ yield using $\mathrm{SmI}_{2}$, was effective to build up the desired difluoromethylene group at $\mathrm{C} 2$ ' position.

By choosing a different reductive reagent, sodium amalgam, Piccirilli et al. [86] transformed $\mathrm{a} \mathrm{CF}_{2}$-containing sulfone into the difluoromethyl group instead of difluoromethylene (Scheme 36 ), and thus prepared 2'-difluoromethyl ribonucleosides (36-4). The key steps included nucleophilic addition of difluoromethyl phenyl sulfone to 2-keto-ribose (36-1) followed by mild and efficient reductive desulfonation.

The terminal monofluoro olefinic group ( $\mathrm{CHF}=\mathrm{C}-)$ is a useful functionality in the design of mechanism-based enzyme inhibitors. McCarthy et al. [87] developed a stereospecific method to construct a terminal $E$ - and $Z$-fluoromethylene group from a carbonyl moiety and found that (E)-2'-fluoromethylene-2'-deoxycytidine, $(E)$-FMC (Scheme 37) shows potent anti-tumor activity against leukemias and solid tumors. Using the Hornor-Wittig reaction, $2^{\prime}-$ ketonucleoside (37-2) was converted to a mixture of readily separable fluorovinyl sulfones $E$ - and Z-(37-3), which can be transformed to fluorovinylstannanes with tributyltin hydride with retention of configuration. (E)-FMC was obtained directly from $E$-fluorovinylstannane in excellent yield.

\section{Biological applications of fluorinated nucleosides}

Fluorinated nucleosides (Figure 6) exhibit a wide variety of biological activity and have been used extensively as anti-tumor [88] and antiviral [89] agents. In many cases, the stability of the nucleoside analogue, particularly the stability of the glycosyl bond, is an important factor determining the biological activity as well as the therapeutic usefulness of nucleosides as drug candidate. Fluorine substitution at the 2'- or 3'-position of a sugar is known to increase the chemical stability of nucleoside analogues, particularly in an acidic environment [49b]. Fluorine substitution also has a favorable affect of increasing the metabolic stability [62]. These findings suggest the importance of a fluorine moiety in the nucleoside as therapeutic agents. Thymidylate synthase, ribonucleotide diphosphate reductase (RDPR) and viral polymerases are the major targets by fluoronucleosides and fluoroheterocyclic bases [90].

\subsection{Antiviral activity of fluoronucleosides}

Viral polymerase is one of the most common and established targets of nucleoside reverse transcriptase inhibitors (NRTIs) in antiviral therapy [91], and the presence of a fluoro group in the nucleoside makes it unique in terms of their chemical, biological and structural properties [92]. For the past several years, Chu and coworkers have been involved in understanding the molecular mechanism of HIV and HBV polymerases and their interaction with nucleoside triphosphates using molecular modeling techniques [93]. Several fluoro nucleosides have been also investigated in terms of their structural and biological profile as polymerase inhibitors. A right hand structure (fingers, palm, and thumb subdomains) were assigned for the structural 
model of polymerase (Figure 7) with respect to HIV reverse transcriptase (HIV-RT) crystal structure [94].

Polymerase catalytic residues are highly conserved [95] and are responsible for the interaction with the template, primer and incoming nucleoside triphosphate. The NRTIs include those compounds which can mimic endogenous pyrimidine or purine nucleosides, and all of them require an intracellular phosphorylation to their triphosphate forms for activity. The first phosphorylation step, often considered as rate limiting, is dependent on deoxynucleoside kinases, such as thymidine kinase, deoxycytidine kinase (dCK) and deoxyguanosine kinase (dGK). Deoxycytidine kinase does not discriminate between the enantiomeric (D \& L) forms of substrates and is able to phosphorylate L-nucleosides in a number of cases [96].

Clevudine (L-FMAU a $\beta$-L-2'-fluoro-thymidine) is an L-nucleoside of thymidine with potent anti-HBV activity [97]. L-FMAU requires step-wise biotransformation to its triphosphate form to exert its pharmacological activities (Figure 8) [98]. The mono phosphorylation is catalyzed by thymidine kinase (TK) along with deoxycytidine kinase (dCK) [99]. The diphosphate formation may be associated with thymidylate kinase (TMPK) activity [100] and finally triphosphate formation is carried out by 3-phosphoglycerate kinase [101]. Experimental evidence suggests that there is no incorporation of L-FMAU into DNA (Scheme 38) [102], an observation that makes this molecule unique in contrast to other nucleoside anti-HBV agents.

In addition, L-FMAU does not inhibit human cellular polymerases and does affect mitochondrial function or host DNA synthetic machinery [102]. The toxicological studies in mice $(50 \mathrm{mg} / \mathrm{Kg} /$ day) and woodchucks (10 mg/Kg/day) suggest no apparent toxicity [97]. The short-term oral administration of L-FMAU to a duck model induced a significant decrease in the level of viremia, without liver toxicity [103]. Another study that included dose-dependent responses in woodchuck showed no drug-related toxicity and exceptional potency against chronic HBV infection [104].

L-FMAU (clevudine) is an oral antiviral agent for the treatment of chronic HBV that has been shown to be well tolerated and has demonstrated potent antiviral activity in clinical studies [105]. Clevudine has been approved for the treatment of chronic hepatitis B virus infection in South Korea in 2006 and is currently undergoing Phase III clinical trials in the US and Europe. Recent phase III clinical trials for 24 weeks [106] at $30 \mathrm{mg}$ clearly demonstrated a potent and sustained antiviral effect associated with sustained normalization of alanine aminotransferase (ALT) levels. This sustained antiviral effect after discontinuation of the drug makes this molecule a unique antiviral agent in comparison to other approved anti-HBV agents. The plausible mechanism of sustained viral suppression may be attributed to the reduction of intrahepatic cccDNA [107]. In addition, immunological factors might be another reason for a sustained anti-HBV activity. These combined mechanisms along with the favorable pharmacokinetic properties may be the reason for the unique antiviral properties of clevudine. Emtricitabine (Figure 6) is another important 5-fluorinated nucleoside that acts as a NRTI, approved for the treatment of HIV infection. A potential disadvantage of this agent is that it may be ineffective against lamivudine-resistant HBV strains and may be associated with the development of similar HBV-resistant mutants. Elvucitabine ( $\beta-\mathrm{L}-\mathrm{Fd} 4 \mathrm{C})$ is another fluoro nucleoside in phase II as a NRTI.

\subsection{Anticancer activity of fluoronucleosides}

Among the important nucleoside analogs [108], fluornucleosides are well documented and explored as potential anticancer agent $[109,110]$. It has been suggested that the induction of apoptosis is the final pathway through which these drugs exert their anticancer activity [111]. These nucleoside analogs mimic natural nucleosides in terms of uptake and metabolism. Further, they can incorporate into newly synthesized DNA resulting in chain termination. Some 
of these drugs also inhibit key enzymes involved in the biosynthesis of purine and pyrimidine nucleotides and RNA synthesis as well as directly activate the apoptosis as an anti-cancer agent.

A recent study showed the importance of one of the fluoro nucleoside, clofarabine [2-chloro(2-deoxy-fluoro- $\beta$-D-arabinofuranosyl)adenine], as a developed new-generation nucleoside analog for acute lymphoblastic leukemia (ALL) [112]. Like other nucleoside analogs, clofarabine exerts its anti-cancer effect by inducing "apoptosis" by blocking DNA synthesis as well as through inhibition of DNA repair [113].

Clofarabine is a newer generation nucleoside anticancer agent related to fludurabine. Fludarabine phosphate (Figure 6) [114] is a C2-fluorinated analog of a purine nucleoside antiviral agent vidarabine (ara-A). Unlike vidarabine, fludarabine phosphate is resistant to deamination by adenosine deaminase. Fludarabine phosphate is a water-soluble prodrug that is rapidly dephosphorylated to 2-fluoro-vidarabine (2F-ara-A). 2F-ara-A is actively transported into cells and is then rephosphorylated via deoxycytidine kinase to the active triphosphate derivative 2F-ara-ATP. 2F-ara-ATP competitively inhibits DNA synthesis via inhibition of DNA polymerase, ribonucleotide reductase, DNA primase, and DNA ligase. 2F-ara-ATP prevents elongation of DNA strands through direct incorporation into DNA as a fraudulent nucleotide. The degree of inhibition of these enzymes is stronger in the case of clofarabine. The mono phosphorylation of clofarabine is substantially more efficient than that of fludarabine [115]. In addition, intracellular retention of clofarabine triphosphate in acute myeloid leukemia (AML) is longer than that of fludarabine, which contributes to the higher potency of clofarabine as an anticancer agent. In addition to its potential effect it can also be given in combination with other anti-cancer agent such as cytarabine [116]. In recent years, a combination of radiotherapy and chemotherapy has emerged as a potential approach in cancer therapy. The current experimental evidence showed that a moderate dose of clofarabine along with radiotherapy led to a significant inhibition of tumor growth [117]. This result suggests the potential of clofarabine as a significant radiosensitizer.

Other well know fluoronucleoside, such as 5-fluorouracil (5-FU), have been used for the treatment of cancer for about 60 years [118]. 5-FU inhibits thymidylate synthase (TS), interrupting the action of an enzyme that converts $2^{\prime}$-deoxyuracilmonophoshate (dUMP) to $2^{\prime}$ deoxythyminemonophosphate (dTMP) via C5-methylation. Some of 5-FU's principal use is in treatment of colorectal cancer as well as pancreatic cancer. 5-Fluorocytosine (flucytosine) is an inhibitor of sterol C-14 demethylase, an enzyme involved in the biosynthesis of ergosterol, an element of fungal cell wall. It is being marketed as an anti-fungal agent [119]. Trifluridine is an anti-herpesvirus drug acting on thymidylate synthase [120]. It is phosphorylated to the triphosphate by the virus-encoded thymidine kinase. The triphosphate inactivates the enzyme thymidine synthetase thus inhibiting DNA synthesis, both in the virus as well as in the host cell. It also competes with naturally occurring thymidine and gets integrated into DNA chain, thus producing fradulant DNA and thus inhibiting virus replication. Tezacitabine is currently in phase III trial for the treatment of solid tumors, such as lung, prostate, ovary, cervix and hematopoietic tissues. Its cytotoxicity has been proposed to originate from synergistic effects between its triphosphate, a DNA chain terminator, and its diphosphate, a stoichiometric inactivator of ribonucleotide reductase.

A another milestone in fluoronucleoside is the development of gemcitabine $\left(2^{\prime}, 2^{\prime}-\right.$ difluorodeoxycytidine, $\mathrm{dFdC}$ ) as an anticancer agent with a broad spectrum of activity that includes activity against solid tumors such as pancreatic cancer. It acts by inhibiting DNA synthesis via competitive incorporation into the growing DNA [121]. It has also a potential role in the treatment of central nervous system malignancies both as a cytotoxic agent as well as a potent radiosensitizer [122,123]. 
Gemcitabine (Figure 6) [124] was launched as Gemzar® by Eli Lilly in 1996 and is currently approved as a first-line treatment for the pancreas adenocarcinoma. It is being used in combination with cisplatin for the treatment of non-small cell lung cancer and with paclitaxel for the treatment of breast cancer. It is proposed as an inhibitor of the ribonucleotide diphosphate reductase, a homodimeric enzyme catalyzing the conversion of nucleotides into deoxynucleotides [125]. It has also been investigated for use in esophageal cancer, and is also used experimentally in lymphomas and various other tumor types. A recent study suggests a differential higher uptake of gemcitabine in brain tumors [126] and it can facilitate higher cytotoxicity to brain tumor cells.

\section{Conclusion}

As highlighted in this review, a number of important pharmaceuticals have been discovered and developed based on fluorinated analogs of biologically active nucleosides. The introduction of fluorine atom(s) into a nucleoside structure at an appropriate position, as a mimic of hydrogen or hydroxyl group or as a fluorinated methyl group, has modulated and/or improved the pharmacological properties of a molecule with minor stereochemistry changes. With progress in synthetic methodologies for selective fluorine-introduction, fluorinated nucleosides will likely continue to be an excellent lead in drug discovery.

\section{Acknowledgement}

This review is partially supported by the grant (AI25899) from the National Institute of Allergy and Infectious Diseases, NIH.

\section{References}

1. Voet, D.; Voet, JG. Biochemistry. Vol. 2nd. John Wiley \& Sons; New York: 1995.

2. Gumina G, Chong Y, Choo H, Song G, Chu CK. Curr. Topics Med. Chem 2002;2:1065-1086.

3. Orr DC, Figueiredo HT, Mo CL, Penn CR, Cameron JM. J. Bio. Chem 1992;267:4177-4182. [PubMed: 1371285]

4 a). Turner MA, Yang X, Yin D, Kuczera K, Borchardt RT, Howell PL. Cell Biochem. Biophys 2000;33:101-125. [PubMed: 11325033] b) Kitade Y, Kozaki C, Miwa T, Nakanishi M. Tetrahedron 2002;58:1271-1277. c) Anderson KS. Biochim. Biophys. Acta 2002;1587:296-299. [PubMed: 12084471]Maga G, Spadari S. Curr. Drug Metab 2002;3:73-96. [PubMed: 11876577]

5 a). Olah, G.; Chambers, R.; Prakash, GKS., editors. Synthetic Fluorine Chemistry. John Wiley and Sons; New York: 1992. Welch JT. Tetrahedron 1987;43:3123-3197. b) Wilkinson JA. Chem. Rev 1992;92:505-519. c) Purrington ST, Kagen BS. Chem. Rev 1986;86:997-1018. d) Schlosser M. Tetrahedron 1978;34:3-17.

6 a). Pankiewicz KR. Carbohydr. Res 2000;327:87-105. [PubMed: 10968677] b) Meng W-D, Qing FL. Curr. Topics Med. Chem 2006;6:1499-1528. c) Ying C, Clercq ED, Neyts J. Curr. Med. Chem. Anti-infective Agents 2003;2:227-240.

7. Wilson LJ, Hager MW, El-Kattan YA, Liotta DC. Synthesis 1995:146-150.

8. Vorbrüggen, H.; Ruh-Pohlenz, C.; Paquette, LA., et al. Organic Reactions Ed. John Wiley and Sons; New York: 2000.

9. Muehlbacher M, Poulter CD. J. Org. Chem 1988;53:1026-1030.

10 a). Hudlicky M. Org. Reactions 1988;35:513-637. b) Wang CJ. Org. Reactions 1985;34:319-400. c) Boswell GA, Ripka WC, Scribner RM, Tullock CW. Org. Reactions 1974;21:1-124.

11 a). Lal SG, Pez GP, Syvret RG. Chem. Rev 1996;96:1737-1756. [PubMed: 11848809] b) Taylor SD, Kotoris CC, Hum G. Tetrahedron 1999:12431-12477. c) Gilicinski AG, Pez GP, Syvret RG, Lal GS. J. Fluorine Chem 1992;59:157-162.

12. Wang X, Seth PP, Ranken R, Swayze EE, Migawa MT. Nucleoside Nucleotides Nucleic Acids 2004;23:161-170. 
13. Visser GWM, Herder RE, Noordhuis P, Zwaagstra O, Jacobus DM, De Kanter FJJ. J. Chem. Soc. Perkin Trans 1988;I:2547-2550.

14. Burkart MD, Zhang Z, Hung S-C, Wong C-H. J. Am. Chem. Soc 1997;119:11743-11746.

15. Li Y, Mao S, Hager MW, Becnel KD, Schinazi RF, Liotta DC. Bioorg. Med. Chem. Lett 2007;17:3398-3401. [PubMed: 17434736]

16. Codington JF, Doerr IL, Fox JJ. J. Org. Chem 1964;29:558-564.

17. Shi J, Du J, Ma T, Pankiewicz KW, Patterson SE, Tharnish PM, McBrayer TR, Stuyver LJ, Otto MJ, Chu CK, Schinazi RF, Watanabe KA. Bioorg. Med. Chem 2005;13:1641-1652. [PubMed: 15698782]

18. Stuyver LJ, McBrayer TR, Whitaker T, Tharnish PM, Ramesh M, Lostia S, Cartee L, Shi J, Hobbs A, Schinazi RF, Watanabe KA, Otto MJ. Antimicrob. Agents Chemother 2004;48:651-654. [PubMed: 14742230]

19. Bajramovic JJ, Volmer R, Syan S, Pochet S, Gonzalez-Dunia1 D. Antimicrob. Agents Chemother 2004;48:1422-1425. [PubMed: 15047559]

20. Pankiewicz KW, Krzeminski J, Ciszewski LA, Ren W, Watanabe KA. J. Org. Chem 1992;57:553559. b) Choi Y, Li L, Grill S, Gullen E, Lee CS, Gumina G, Tsujii E, Cheng Y-C, Chu CK. J. Med. Chem 2000;43:2538-2546. [PubMed: 10891113]

21 a). Clark JL, Mason JC, Hollecker L, Stuyver LJ, Tharnish PM, McBrayer TR, Otto MJ, Furman PA, Schinazi RF, Watanabe KA. Bioorg. Med. Chem. Lett 2006;16:1712-1715. [PubMed: 16368235] b) Clark JL, Hollecker L, Mason JC, Stuyver LJ, Tharnish PM, Lostia S, McBrayer TR, Schinazi RF, Watanabe KA, Otto MJ, Furman PA, Stec WJ, Patterson SE, Pankiewicz KW. J. Med. Chem 2005;48:5504-5508. [PubMed: 16107149]

22. Murakami E, Bao H, Ramesh M, McBrayer TR, Whitaker T, Steuer HMM, Schinazi RF, Stuyver LJ, Obikhod A, Otto MJ, Furman PA. Antimicrob. Agents Chemother 2007;51:503-509. [PubMed: 17101674]

23. McAtee JJ, Schinazi RF, Liotta DC. J. Org. Chem 1998;63:2161-2167.

24 a). Wright JA, Taylor NF, Fox JJ. J. Org. Chem 1969;34:2632-2636. [PubMed: 5803811] b) Reichman U, Watanabe YA, Fox JJ. Carbohydr. Res 1975;42:233-240. [PubMed: 1139559] c) Watanabe KA, Su T-L, Klein RS, Chu CK, Matsuda A, Chun MW, Lopez C, Fox JJ. J. Med. Chem 1983;26:152156. [PubMed: 6298422] d) Watanabe KA, Su T-L, Reichman U, Greenberg N, Lopez C, Fox JJ. J. Med. Chem 1984;27:91-94. [PubMed: 6317862] e) Perlman ME, Watanabe KA, Schinazi RF, Fox JJ. J. Med. Chem 1985;28:741-748. [PubMed: 4009596] f) Su T-L, Watanabe KA, Schinazi RF, Fox JJ. J. Med. Chem 1986;29:151-154. [PubMed: 3001306]

25. Abbruzzese JL, Schmidt S, Raber MN, Levy JK, Castellanos AM, Legha SS, Krakoff IH. Invest. New Drugs 1989;7:195-197. [PubMed: 2793372]

26. McKenzie R, Fried MW, Sallie R, Varam H. ConJee, Di Bisceglie AM, Park Y, Savararese B, Kleiner D, Tsokos M, Luciano C, Pruett T, Stotka JL, Straus SE, Hoofnagle JH. N. Engl. J. Med 1995;333:1099-1116. [PubMed: 7565947]

27. Chu CK, Ma T, Shanmuganathan K, Wang C, Xiang Y, Pai SB, Tao G-Q, Sommadossi J-P, Cheng Y-C. Antimicrob. Agents Chemother 1995;39:979-981. [PubMed: 7786007]

28 a). Montgomery JA, Shortnacy AT, Carson DA, Secrist JA III. J. Med. Chem 1986;29:2389-2392. [PubMed: 3783596] b) Montgomery JA, Shortnacy AT, Clayton SD, Riordan JM, Secrist JA III. J. Med. Chem 1992;35:397-401. [PubMed: 1732556] c) Bauta WE, Schulmeier BE, Burke B, Puente JF, Cantrell WR, Lovett D, Goebel J, Anderson B, Ionescu D, Guo R. Org. Proc. Res. Dev 2004;8:889-896. d) Bonate PL, Arthaud L, Cantrell WR Jr. Stephenson K, Secrist JA, Weitman S. Nature Reviews 2006;5:855-857.

29 a). Machida H, Ashida N, Miura S, Endo M, Yamada K, Kitano K, Yoshimura Y, Sakata S, Ijichi O, Eizuru Y. Antiviral Res 1998;39:129-137. [PubMed: 9806489] b) Satoh H, Yashimura Y, Sakata S, Miura S, Machida H. Bioorg. Med. Chem. Lett 1998;8:989-992. [PubMed: 9871694]

30. Borthwick AD, Evans DN, Kirk BE, Biggadike K, Exall AM, Roberts AM, Youds PM, Knight J, Coates JA. J. Med. Chem 1990;33:179-186. [PubMed: 2153201]

31. Biggadike K, Borthwick AD, Exall AM, Kirk BE, Ward RA. J. Chem. Soc. Chem. Commun 1988:898-890.

32. Tann CH, Brodfuehrer PR, Brundidge SP, Sapino C, Howell HG. J. Org. Chem 1985;50:3644-3647. 
33 a). Juaristi E, Cuevas G. Tetrahedron 1992;48:5019-5087. b) Box VGS. Heterocycles 1990;31:1157. c) Box VGS. Heterocycles 1991;32:795-807.

34. Wright JA, Taylor NF, Fox JJ. J. Org. Chem 1969;34:2632-2636. [PubMed: 5803811]

35 a). Chu CK, Matulic-Adamic J, Huang J-T, Chou T-C, Burchenal JH, Fox JJ, Watanabe KA. Chem. Pharm. Bull 1989;37:336-338. [PubMed: 2743479] b) Marquez VE, Tseng CK-H, Mitsuya H, Aoki S, Kelley JA, Ford H, Roth JS, Broder S, Johns DG, Driscoll JS. J. Med. Chem 1990;33:978985. [PubMed: 2106581]

36. Krzeminski J, Nawrot B, Pankiewicz KW, Watanabe KA. Nucleosides Nucleotides 1991;10:781786.

37. Sivetsa GG, Kalinichenkoa EN, Mikhailopulo IA. Lett. Org. Chem 2006;3:402-405.

38. Ma T, Pai SB, Zhu YL, Lin JS, Shanmuganathan K, Du J, Wang C, Kim H, Newton MG, Cheng YC, Chu CK. J. Med. Chem 1996;39:2835-2843. [PubMed: 8709113]

39. Du J, et al. Nulceosides Nucleotides 1999;18:187-192.

40. Siddiqui MA, Driscoll JS, Marquez VE, Roth JS, Shirasaka T, Mitsuya H, Barchi JJ, Kelleyt JA. J. Med. Chem 1992;35:2195-2201. [PubMed: 1351945]

41 a). Van Aerschot A, Herdewijn P, Balzarini J, Pauwels R, De Clercq E. J. Med. Chem 1989;32:17431749. [PubMed: 2754700] b) Barchi JJ, Marquez VE, Driscoll JS, Ford H, Mitsuya H, Shirasaka T, Aoki S, Kelleyf JA. J. Med. Chem 1991;34:1647-1655. [PubMed: 2033591] c) Bhattacharya BK, Ojwang JO, Rando RF, Huffman JH, Revankar GR. J. Med. Chem 1995;38:3957-3966. [PubMed: 7562929] d) Izawa K, Takamatsu S, Katayama S, Hirose N, Kozai S, Maruyama T. Nucleosides Nuceotides Nucleic Acids 2003;22:507-517.

42 a). Shanmuganathan K, Koudriakova T, Nampalli S, Du J, Gallo JM, Schinazi RF, Chu CK. J. Med. Chem 1994;37:821-827. [PubMed: 8145233] b) Kotra LP, Wang P, Bartlett MG, Shanmuganathan K, Xu Z, Cavalcanti S, Newton MG, Chu CK. J. Org. Chem 1997;62:7267-7271. [PubMed: 11671839] c) Xiang Y, Cavalcanti S, Chu CK, Schinazi RF, Pal SB, Zhu Y-L, Cheng Y-C. Bioorg. Med. Chem. Lett 1995;5:877-880.

43. Okabe M, Sun R-C, Zenchoff GB. J. Med. Chem 1991;56:4392-4396.

44 a). Takamatsu S, Katayama S, Hirose N, De Cock E, Schelkens G, Demillequand M, Brepoels J, Izawa K. Nucleosides Nuceotides Nucleic Acids 2002;21:849-862. b) Takamatsu S, Maruyama T, Katayama S, Hirose N, Naito M, Izawa K. J. Org. Chem 2001;66:7469-7477. [PubMed: 11681963]

45 a). Siddiqui MA, Driscoll JS, Abushanab E, Kelley JA, Barchi JJ Jr. Marquez VE. Nucleosides Nuceotides Nucleic Acids 2000;19:1-10. b) Woltermann CJ, Lapin YA, Kunnen KB, Tueting DR, Sanchez IH. Tetrahedron 2004;60:3445-3449.

46. Hertel LW, Kroin JS, Misner JW, Tustin JM. J. Org. Chem 1988;53:85-88.

47. Kotra LP, Xiang Y, Newton MG, Schinazi RF, Cheng Y-C, Chu CK. J. Med. Chem 1997;40:36353644. [PubMed: 9357530]

48. Kotra LP, Newton MG, Chu CK. Carbohydr. Res 1998;306:69-80. [PubMed: 9691440]

49 a). Choi Y, Lee K, Hong JH, Schinazi RF, Chu Chung K. Tetrahedron Lett 1998;39:4437-4441.Lee K, Choi Y, Gullen E, Schlueter-Wirtz S, Schinazi RF, Cheng Y-C, Chu CK. J. Med. Chem 1999;42:1320-1328. [PubMed: 10197975] b) Lee K, Choi Y, Gumina G, Zhou W, Schinazi RF, Chu CK. J. Med. Chem 2002;45:1313-1320. [PubMed: 11882000] c) Choi Y, Choo H, Chong Y, Lee S, Olgen S, Schinazi RF, Chu CK. Org. Lett 2002;2:305-307. [PubMed: 11796076] d) Chong Y, Choo H, Choi Y, Mathew J, Schinazi RF, Chu CK. J. Med. Chem 2002;45:4888-4898. [PubMed: 12383014] e) Choo H, Chong Y, Choi Y, Mathew J, Schinazi RF, Chu CK. J. Med. Chem 2003;46:389-398. [PubMed: 12540238] f) Wang J, Jin Y, Rapp KL, Bennett M, Schinazi RF, Chu CK. J. Med. Chem 2005;48:3736-3748. [PubMed: 15916425]

50. Marquez, VE.; Lim, BB.; Barchi, JJ.; Nicklaus, MC. Nucleosides and Nucleotides as Antitumor and Antiviral Agents. Chu, CK.; Baker, DC., editors. Plenum; New York: 1993. p. 265-284.

51. Herdewijn P, Balzarini J, De Clercq E, Pauwels R, Baba M, Broder S, Vanderhaeghe H. J. Med. Chem 1987;30:1270-1278. [PubMed: 3497272]

52 a). Balzarini J, Baba M, Pauwels R, Herdewijn J, De Clercq E. Biochem. Pharmacol 1988;37:28472856. [PubMed: 2840080] b) Mathes E, Lehmann CH, Scholz D, von Janta-Lipinski M, Gaertner K, Rosenthal HA, Langen P. Biochem. Biophys. Res. Commun 1987;148:78-85. [PubMed: 2445344] 
53 (a). Blzarini J, Aerschot A, Pauwels R, Baba M, Scholz D, Herdewijn P, De Clercq E. Mol. Phamacol 1989;35:571-577. (b) Daluge S, Purifoy DJM, Savina PM, Clair MH, Parry NR, Dev IK, Novak P, Ayers KM, Reardon JE, Roberts GB, Eyfe JA, Blum MB, Averett DR, Dornsife RE, Domin BA, Ferone R, Lewis DA, Krenitsky TA. Antimicrob. Agents Chemother 1994;38:1591-1603.

54. Chun BK, Schinazi RF, Cheng Y-C, Chu CK. Carbohydr. Res 2000;328:49-59. [PubMed: 11005575] 55. Baumgarten H, Bodenteich M, Griengl H. Tetrahedron Lett 1988;29:5745-5749.

56 a). Kumar P, Ohkura K, Balzarini J, De Clercq E, Seki K, Wiebe LI. Nucleosides Nucleotides Nucleic Acids 2004;23:7-29. [PubMed: 15043133] b) Carangio A, McGuigan C, Andrei G, Snoeck R, De Clercq E, Balzarini J. Nucleosides Nucleotides Nucleic Acids 2003;22:935-937. [PubMed: 14565315] c) Marchand A, Mathe C, Imbach J-L, Gosselin G. Nucleosides Nucleotides Nucleic Acids 2000;19:205-217. [PubMed: 10772710] d) von Janta-Lipinski M, Costisella B, Ochs H, Hubscher U, Hafkemeyer P, Matthes E. J. Med. Chem 1998;41:2040-2046. [PubMed: 9622545]

57. Torii T, Onishi T, Izawa K, Maruyama T, Demizu Y, Neyts J, De Clercq E. Nucleosides Nucleotides Nucleic Acids 2006;25:655-665. [PubMed: 16838853]

58 a). Chun BK, Schinazi RF, Cheng Y-C, Chu CK. Carbohydr. Res 2000;328:49-59. [PubMed: 11005575] b) Herdewijn P, Pauwels R, Baba M, Balzarini J, De Clercq E. J. Med. Chem 1987;30:2131-2137. [PubMed: 3499515] c) Puech F, Gosselin G, Imbach J-L. Tetrahedron Lett 1989;30:3171-3175. d) Van Aerschot A, Herdewijn P, Janssen G, Cools M, De Clercq E. Antiviral Res 1989;12:133-150. [PubMed: 2624455] e) Mort CJW, Migaud ME, Galioneb A, Pottera BVL. Bioorg. Med. Chem 2004;12:475-487. [PubMed: 14723966]

59. Pierra C, Imbach J-L, De Clercq E, Balzarini J, Aerschot AV, Herdewijn P, Faraj A, Loi AG, Sommadossi J-P, Gosselin G. Antiviral Res 2000;45:169-183. [PubMed: 10771081]

60 a). Robins MJ, Nowak I, Wnuk SF, Hansske F, Madej D. J. Org. Chem 2007;72:8216-8221. [PubMed: 17918996] b) Kawana M, Kuzuhara H. Carbohydr. Res 1989;189:181-193. c) Timoshchuk, Victor A.; Hogrefe, Richard I.; Vaghefi, Morteza M. Nucleosides Nucleotides Nucleic Acids 2004;23:171181. [PubMed: 15043145] d) Torii T, Onishi T, Izawa K, Maruyama T, Demizu Y, Neyts J, De Clercq E. Nucleosides Nucleotides Nucleic Acids 2006;25:655-665. [PubMed: 16838853]

61 a). Takamatsu S, Katayama S, Naito M, Yamashita K, Ineyama T, Izawa K. Nucleosides Nucleotides Nucleic Acids 2003;22:711-713. [PubMed: 14565260] b) Torii T, Onishi T, Tanji S, Izawa K. Nucleosides Nucleotides Nucleic Acids 2005;24:1051-1054. [PubMed: 16248090] c) Katayama S, Takamatsu S, Naito M, Tanji S, Ineyama T, Izawa K. J. Fluorine Chem 2006;127:524-528.

62 a). Gumina G, Schinazi RF, Chu CK. Org. Lett 2001;3:4177-4181. [PubMed: 11784171] b) Chong Y, Gumina G, Mathew JS, Schinazi RF, Chu CK. J. Med. Chem 2003;46:3245-3256. [PubMed: 12852755] c) Zhou W, Gumina G, Chong Y, Wang J, Schinazi RF, Chu CK. J. Med. Chem 2004;47:3399-3408. [PubMed: 15189036]

63. Zhu W, Chong Y, Choo H, Mathews J, Schinazi RF, Chu CK. J. Med. Chem 2003;46:1631-1640.

64. Wang J, Jin Y, Rapp KL, Schinazi RF, Chu CK. J. Med. Chem 2007;50:1828-1839. [PubMed: 17373782]

65 a). Zhang X, Xia H, Dong X, Jin J, Meng W-D, Qing F-L. J. Org. Chem 2003;68:9026-9033. [PubMed: 14604377] b) Xu X-H, Qiu X-L, Zhang X, Qing F-L. J. Org. Chem 2006;71:2820-2824. [PubMed: 16555837]

66. De Clercq E. J. Med. Chem 2005;48:1297-1313. [PubMed: 15743172]

67. Choo H, Chong Y, Chu CK. Bioorg. Med. Chem. Lett 2003;13:1993-1996. [PubMed: 12781181]

68 a). Waga T, Ohrui H, Meguro H. Nucleosides Nucleotides 1996;15:287-304. b) Yamaguchi T, Tomikawa A, Hirai T, Kawaguchi T, Ohrui H, Saneyoshi M. Nucleosides Nucleotides 1997;16:1347. c) Waga T, Nishizaki T, Ohrui H, Meguro H. Biosci. Biotechnol. Biochem 1993;57:1433-1438. [PubMed: 7764216]

69 a). Chen MS, Suttmann RT, Wu JC, Prisbe EJ. J. Biol. Chem 1992;267:257-260. [PubMed: 1730594] b) Chen MS, Suttmann RT, Papp E, Cannon PD, McRobierts MJ, Bach C, Copeland WC, Wang T. Biochemistry 1993;32:6002-6005. [PubMed: 7685186]

70 a). Ohrui H, Kohgo S, Kitano K, Kodama E, Yoshimura K, Matsuoka M, Shigeta S, Mitsuya H. J. Med. Chem 2000;43:4516-4525. [PubMed: 11087576] b) Summerer D, Marx A. Bioorg. Med. Chem. Lett 2005;15:869-871. [PubMed: 15686877] c) Kodama E, Kohgo S, Kitano K, Machida 
H, Gatanaga H, Shigeta S, Matsuoka M, Ohrui H, Mitsuya H. Antimicrob. Agents Chemother 2001;45:1539-1546. [PubMed: 11302824]

71. Chen X, Zhou W, Schinazi RF, Chu CK. J. Org. Chem 2004;69:6034-6041. [PubMed: 15373488]

72. Maag H, Rydzewski RM, McRoberts MJ, Crawford-Ruth D, Verheyden JPH, Prisbe EJ. J. Med. Chem 1992;35:1440-1451. [PubMed: 1573638]

73. Liu P, Sharon A, Chu CK. Tetrahedron Assymetry 2006:3304-3314.

74 a). Jenkins ID, Verheyden JPH, Moffatt JC. J. Am. Chem. Soc 1971;93:4323-4324. [PubMed: 5131149] b) Jenkins ID, Verheyden JPH, Moffatt JG. J. Am. Chem. Soc 1976;98:3346-3357. [PubMed: 1262649] c) Owen GR, Verheyden JPH, Moffatt JG. J. Org. Chem 1976;41:3010-3017. [PubMed: 134137]

75. Hong JH, Lee K, Choi Y, Chu CK. Tetrahedron Lett 1998;39:3443-3447.

76. Gumina G, Chong Y, Choi Y, Chu CK. Org. Lett 2000;2:1229-1232. [PubMed: 10810714]Chong Y, Gumina G, Chu CK. Tetrahedron Asymmetry 2000;11:4853-4875.

77 a). Xiang Y, Kotra LP, Chu CK, Schinazi RF. Bioorg. Med. Chem. Lett 1995;5:743-747.Xiang Y, Cavalcanti S, Chu CK, Schinazi RF, Pai SB, Zhu Y-L, Cheng Y-C. Bioorg. Med. Chem. Lett 1995;5:877-881. b) Pai SB, Liu S-H, Zhu Y-L, Chu CK, Cheng Y-C. Antimicrob. Agents Chemother 1996;40:380-386. [PubMed: 8834884] c) Ma T, Pai SB, Zhu YL, Lin J-S, Shanmuganathan K, Du J, Wang C, Kim H, Newton MG, Cheng Y-C, Chu CK. J. Med. Chem 1996;39:2835-2843. [PubMed: 8709113] d) Ma T, Lin J-S, Newton MG, Cheng Y-C, Chu CK. J. Med. Chem 1997;40:2750-2754. [PubMed: 9276020]Kotra LP, Xiang Y, Newton MG, Schinazi RF, Cheng Y-C, Chu CK. J. Med. Chem 1997;40:3635-3644. [PubMed: 9357530] e) Choi Y, Lee K, Hong JH, Schinazi RF, Chu CK. Tetrahedron Lett 1998;39:4437-4441. f) Lee K, Choi Y, Gullen E, Schlueter-Wirtz S, Schinazi RF, Cheng Y-C, Chu CK. J. Med. Chem 1999;7:1320-1328. [PubMed: 10197975] g) Lee K, Choi Y, Hong JH, Schinazi RF, Chu CK. Nucleosides Nucleotides 1999;18:537-540. [PubMed: 10432644] h) Marquez VE, Tseng CK-H, Mitsuya H, Aoki S, Kelley JA, Ford H Jr. Driscoll JS. J. Med. Chem 1990;33:978-985. [PubMed: 2106581]

78. Blackburn GM, England DE, Kolkmann F. J. Chem. Soc., Chem. Commun 1981:930-936.

79. Yang Y-Y, Meng W-D, Qing F-L. Org. Lett 2004;6:4257-4261. [PubMed: 15524457]

80. Wachtmeister J, Classon B, Samuelsson B. Tetrahedron 1997;53:1861-1872.

81. McClinton MA, McClinton DA. Tetrahedron 1992;48:6555-6666.

82. Sharma PK, Nair V. Nucleosides Nucleotides Nucleic Acids 2000;19:757-762. [PubMed: 10960034] 83. Jeannot F, Gosselin G, Mathé C. Org. Biomol. Chem 2003;1:2096-2102. [PubMed: 12945900]

84 a). Serafinowski PJ, Brown CA. Tetrahedron 2000;56:333-339. b) Serafinowski PJ, Brown CA, Barnes CL. Nucleosides Nucleotides Nucleic Acids 2001;20:921-926. [PubMed: 11563145]

85. McCarthy JR, Jarvi ET, Matthews DP, Edwards ML, Prakash NJ, Bowlin TL, Mehdi S, Sunkara PS, Bey P. J. Am. Chem. Soc 1989;111:1127-1128.

86. Ye J-D, Liao X, Piccirilli JA. J. Org. Chem 2005;70:7902-7910. [PubMed: 16277309]

87 a). McCarthy JR, Matthews DP. J. Am. Chem. Soc 1991;113:7439-7440. b) van der Donk WA, Gerfen GJ, Stubbe J. J. Am. Chem. Soc 1998;120:4252-4253. c) van der Donk WA, Yu G, Silva DJ, Stubbe J. Biochem 1996;35:8381-8383. [PubMed: 8679596]

88 a). Yamamoto Y, Nishiyama Y, Kimura N, Ishikawa S, Okuda M, Bandoh S, Kanaji N, Asakura M, Ohkawa M. Eur. J. Nucl. Med. Mol. Imaging 2008;35:236-245. [PubMed: 17909790] b) Manta S, Agelis G, Botic T, Cencic A, Komiotis D. Eur. J. Med. Chem 2008;43:420-428. [PubMed: 17548129]

89 a). Murakami E, Niu C, Bao H, Steuer H. M. Micolochick, Whitaker T, Nachman T, Sofia MA, Wang P, Otto MJ, Furman PA. Antimicrob. Agents Chemother 2008;52:458-464. [PubMed: 17999967]

b) Li W, Yin X, Schneller SW. Bioorg. Med. Chem. Lett 2008;18:220-222. [PubMed: 18023578]

90. Bégué J-P, Bonnet-Delpon D. J. Fluorine Chem 2006;127:992-1012.

91 a). Cihlar T, Ray AS, Boojamra CG, Zhang L, Hui H, Laflamme G, Vela JE, Grant D, Chen J, Myrick F, White KL, Gao YY, Lin KY, Douglas JL, Parkin NT, Carey A, Pakdaman R, Mackman RL. Antimicrob. Agents. Chemother 2008;52:655-665. [PubMed: 18056282] b) Manta S, Agelis G, Botic T, Cencic A, Komiotis D. Bioorg. Med. Chem 2007;15:980-987. [PubMed: 17079149] 
92 a). Kore AR, Shanmugasundaram M, Charles I, Cheng AM, Barta TJ. Bioorg. Med. Chem. Lett 2007;17:5295-5299. [PubMed: 17728131] b) Seela F, Xu K, Chittepu P, Ming X. Nucleosides Nucleotides Nucleic Acids 2007;26:607-610. [PubMed: 18066864]

93 a). Lee K, Chong Y, Chu CK. Nucleosides Nucleotides Nucleic Acids 2001;20:385-389. [PubMed: 11563052] b) Lee K, Chu CK. Antimicrob. Agents. Chemother 2001;45:138-144. [PubMed: 11120956] c) Chong Y, Akula N, Chu CK. Bioorg. Med. Chem. Lett 2003;13:4019-4022. [PubMed: 14592498] d) Choo H, Chong Y, Chu CK. Bioorg. Med. Chem. Lett 2003;13:1993-1996. [PubMed: 12781181] e) Chong Y, Chu CK. Front Biosci 2004;9:164-165. [PubMed: 14766357]

94. Huang H, Chopra R, Verdine GL, Harrison SC. Science 1998;282:1669-1675. [PubMed: 9831551]

95. Bartholomeusz A, Tehan BG, Chalmers DK. Antivir. Ther 2004;9:149-152. [PubMed: 15134177]

96. Sabini E, Hazra S, Konrad M, Burley SK, Lavie A. Nucl. Acids Res 2007;35:186-192. [PubMed: 17158155]

97 a). Chu CK, Boudinot FD, Peek SF, Hong JH, Choi Y, Korba BE, Gerin JL, Cote PJ, Tennant BC, Cheng YC. Antivir. Ther 1998;3:113-121. [PubMed: 10726061] b) Hui CK, Lau GK. Expert Opin Investig. Drugs 2005;14:1277-1284.

98. De Clercq E. Int. J. Antimicrob. Agents 1999;12:81-95. [PubMed: 10418752]

99. Liu SH, Grove KL, Cheng YC. Antimicrob. Agents Chemother 1998;42:833-839. [PubMed: 9559792]

100. Hu R, Li L, Degreve B, Dutschman GE, Lam W, Cheng YC. Antimicrob. Agents Chemother 2005;49:2044-2049. [PubMed: 15855530]

101. Krishnan P, Gullen EA, Lam W, Dutschman GE, Grill SP, Cheng YC. J. Biol. Chem 2003;278:36726-36732. [PubMed: 12869554]

102. Pai, S. Balakrishna; Liu, SH.; Zhu, YL.; Chu, CK.; Cheng, YC. Antimicrob. Agents Chemother 1996;40:380-386. [PubMed: 8834884]

103. Aguesse-Germon S, Liu SH, Chevallier M, Pichoud C, Jamard C, Borel C, Chu CK, Trepo C, Cheng YC, Zoulim F. Antimicrob. Agents Chemother 1998;42:369-376. [PubMed: 9527788]

104. Peek SF, Cote PJ, Jacob JR, Toshkov IA, Hornbuckle WE, Baldwin BH, Wells FV, Chu CK, Gerin JL, Tennant BC, Korba BE. Hepatology 2001;33:254-266. [PubMed: 11124844]

105 a). Marcellin P, Mommeja-Marin H, Sacks SL, Lau GK, Sereni D, Bronowicki JP, Conway B, Trepo C, Blum MR, Yoo BC, Mondou E, Sorbel J, Snow A, Rousseau F, Lee HS. Hepatology 2004;40:140-150. [PubMed: 15239097] b) Lee HS, Chung YH, Lee K, Byun KS, Paik SW, Han JY, Yoo K, Yoo HW, Lee JH, Yoo BC. Hepatology 2006;43:982-988. [PubMed: 16628625]

106. Yoo BC, Kim JH, Chung YH, Lee KS, Paik SW, Ryu SH, Han BH, Han JY, Byun KS, Cho M, Lee HJ, Kim TH, Cho SH, Park JW, Um SH, Hwang SG, Kim YS, Lee YJ, Chon CY, Kim BI, Lee YS, Yang JM, Kim HC, Hwang JS, Choi SK, Kweon YO, Jeong SH, Lee MS, Choi JY, Kim DG, Kim YS, Lee HY, Yoo K, Yoo HW, Lee HS. Hepatology 2007;45:1172-1178. [PubMed: 17464992]

107. Zhu Y, Yamamoto T, Cullen J, Saputelli J, Aldrich CE, Miller DS, Litwin S, Furman PA, Jilbert AR, Mason WS. J. Virol 2001;75:311-322. [PubMed: 11119601]

108. Elion GB. Science 1989;244:41-47. [PubMed: 2649979]

109. Heidelberger C, Danenberg PV, Moran RG. Adv. Enzymol. Relat. Areas Mol. Biol 1983;54:58119. [PubMed: 6189380]

110. Harbers E, Chaudhuri NK, Heidelberger C. J. Biol. Chem 1959;234:1255-1262. [PubMed: 13654358]

111. Huang P, Robertson LE, Wright S, Plunkett W. Clin. Cancer. Res 1995;1:1005-1013. [PubMed: 9816073]

112. Montgomery JA, Shortnacy-Fowler AT, Clayton SD, Riordan JM, Secrist JA 3rd. J. Med. Chem 1992;35:397-401. [PubMed: 1732556]

113. Faderl S, Gandhi V, Kantarjian HM. Curr. Opin Hematol 2008;15:101-107. [PubMed: 18300755]

114. Duschinsky R, Pleven E, Heidelberger C. J. Am. Chem. Soc 1957;79:4559-4560.Isanbor C, O'Hagan D. J. Fluorine Chem 2006;127:303-319.

115. Xie C, Plunkett W. Cancer Res 1995;55:2847-2852. [PubMed: 7540950]

116. Gidwani P, Ramesh KH, Liu Y, Kolb EA. Chemotherapy 2008;54:120-124. [PubMed: 18303261] 
117. Cariveau MJ, Stackhouse M, Cui XL, Tiwari K, Waud W, Secrist JA 3rd, Xu B. Int. J. Radiat. Oncol. Biol. Phys 2008;70:213-220. [PubMed: 18037589]

118. Heidelberger C, Chaudhuri NK, Danneberg P, Mooren D, Griesbach L, Duschinsky R, Schnitzer RJ, Pleven E, Scheiner J. Nature 1957;179:663-664. [PubMed: 13418758]

119. De Clercq E, Descamps J, De Somer P, Barr PJ, Jones AS, Walker RT. Proc. Nat. Acad. Sci. U. S. A 1979;76:2947-2948.Heidelberger C, King DH. Pharmacol. Therap 1979;6:427-442.

120. Hertel, LW.; Kroin, JS.; Grossman, CS.; Grindey, GB.; Dorr, AF.; Storniolo, AMV.; Plunkett, W.; Ganghi, V.; Huang, P. Biomedical Frontiers of Fluorine Chemistry. Ojima, I.; McCarthy, J.; Welch, JT., editors. Washington, DC: 1996. p. 265-278.ACS Symposium Series 639

121. Plunkett W, Huang P, Xu YZ, Heinemann V, Grunewald R, Gandhi V. Semin Oncol 1995;22:310. [PubMed: 7481842]

122. Rieger J, Durka S, Streffer J, Dichgans J, Weller M. Eur. J. Pharmacol 1999;365:301-308. [PubMed: 9988115]

123. Fehlauer F, Muench M, Smid EJ, Slotman B, Richter E, Van der Valk P, Sminia P. Oncol Rep 2006;15:97-105. [PubMed: 16328040]

124. McCarthy, R.; Sunkara, PS.; Matthews, DP.; Bitonti, AJ.; Jarvi, EJ.; Sabol, JS.; Resvick, RJ.; Huber, EW.; van der Donk, WA.; Yu, G.; Stubbe, JA. Biomedical Frontiers of Fluorine Chemistry. Ojima, I.; McCarthy, J.; Welch, JT., editors. Washington, DC: 1996. p. 246-264.ACS Symposium Series 639

125. Nishida H, Murase T, Ueno H. Leukemia Res 2006;30:1589. [PubMed: 16542723]Anderson VR, Perry CM. Drugs 2007;67:1633-1644. [PubMed: 17661532]

126. Apparaju SK, Gudelsky GA, Desai PB. Cancer Chemother Pharmacol 2008;61:223-229. [PubMed: 17443325] 
Nucleophilc Fluorinating Agents
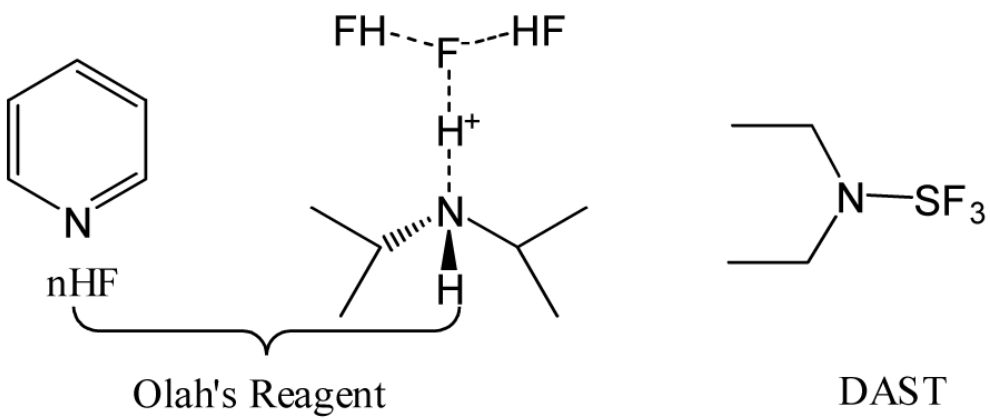

Electrophilc

Fluorinating Agents<smiles>FN1CCN(CCl)CC1</smiles>

Selecfluor<smiles>O=S(=O)(c1ccccc1)N(F)S(=O)(=O)c1ccccc1</smiles>

NFSI

Figure 1.

Common fluorinating agents 


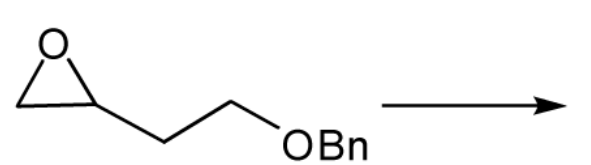

1-1

Reagent: $\quad \mathrm{Et}_{3} \mathrm{~N} .3 \mathrm{HF}$

Py.nHF

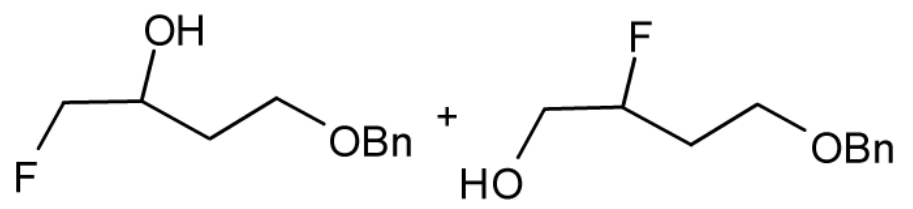

1-2

Ratio: 6 : 1

$1: 4$
1-3

Yield, $81 \%$

$68 \%$

Scheme 1. 


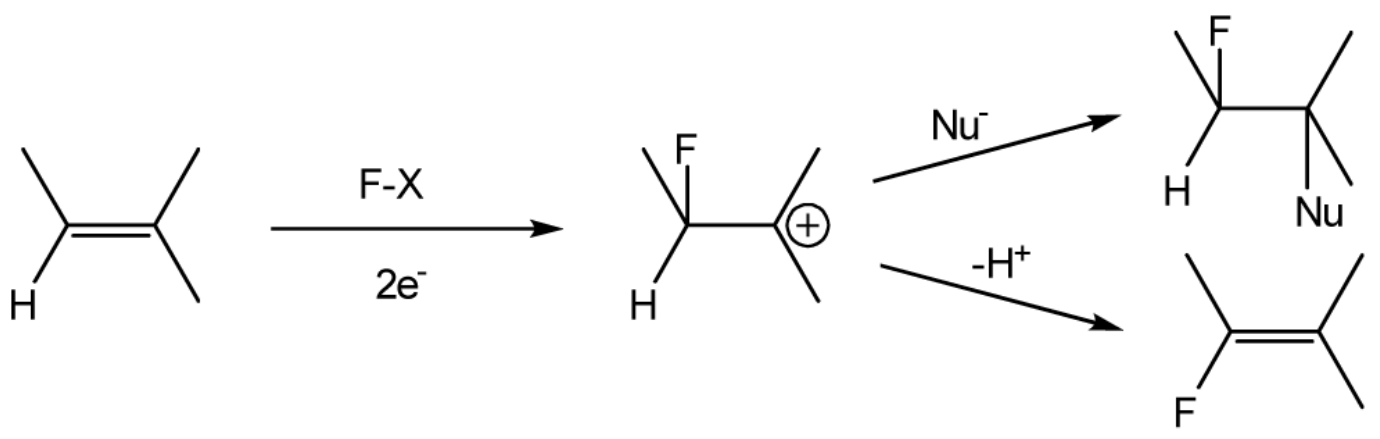

Scheme 2. 
<smiles></smiles>

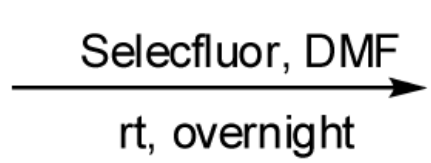<smiles>O=c1ccn(SBr)c(=O)[nH]1</smiles><smiles>C[AsH]C([GeH2])[GeH3]</smiles>

\section{3-3}<smiles>Fc1c[nH]c2ncnc(Cl)c12</smiles><smiles>O=c1[nH]c(=O)n([As]Cl)cc1F</smiles>

Scheme 3. 

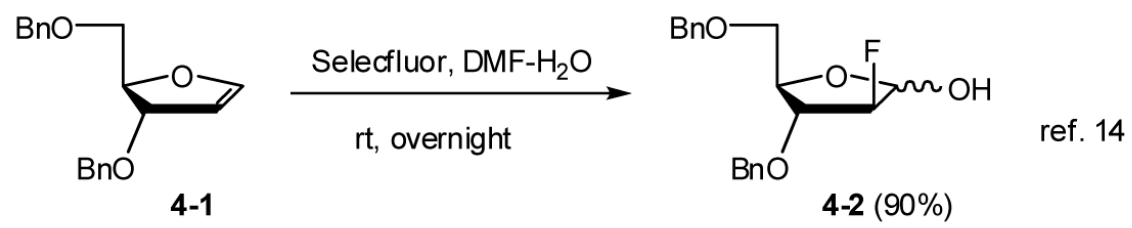

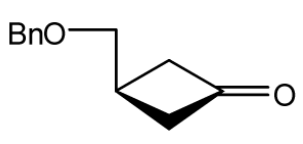

4-3

1) LDA, THF, $-78^{\circ} \mathrm{C}$ then $0^{\circ} \mathrm{C}$

2) $\mathrm{TMSCl}$, $0^{\circ} \mathrm{C}$ then $\mathrm{rt}$

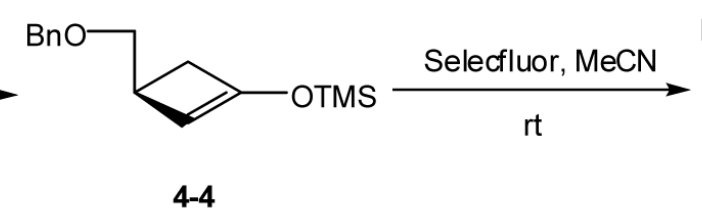

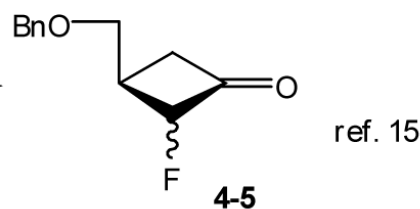

Scheme 4. 
<smiles>[R]c1cn([C@H]2O[C@H](CO)[C@@H](O)[C@H]2O)c(=O)[nH]c1=O</smiles>

Scheme 5. 
<smiles>[R]c1cn2c(nc1=O)OC[C@H]2O</smiles>

6-1 a. $R=H ; b . R=M e ; c . ~ R=F$

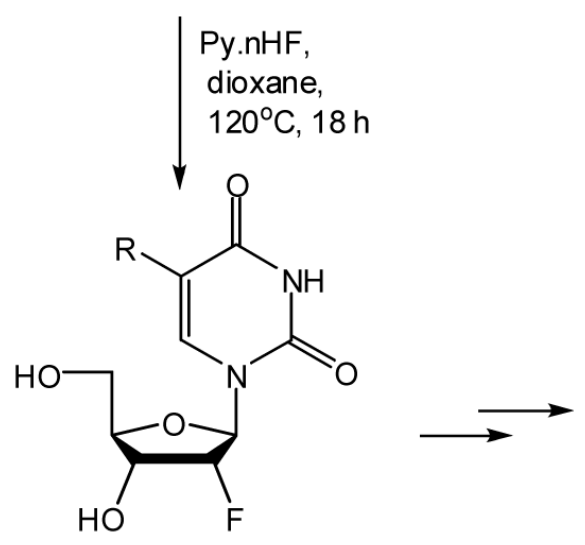

6-4 a. R=H; b. R=Me

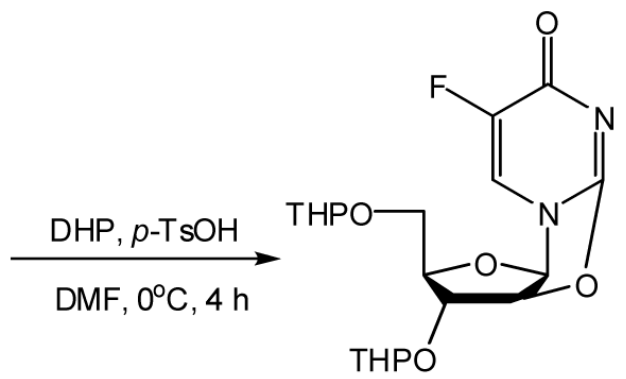

6-2

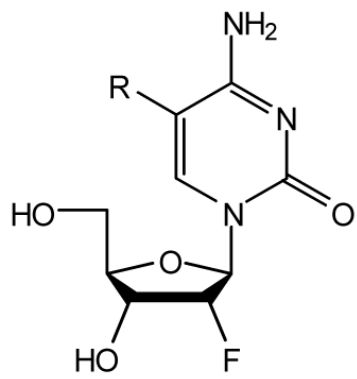

6-6 a. R=H; b. R=Me; c. R=F

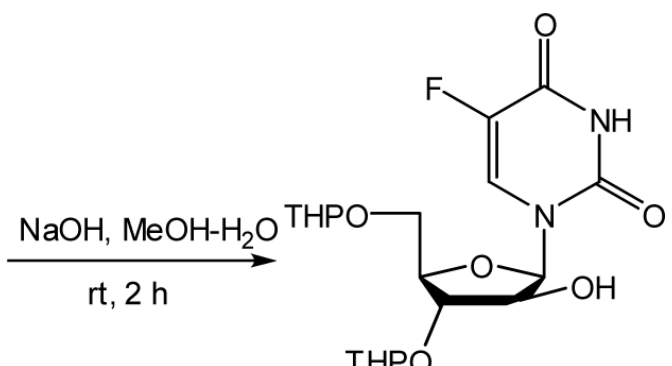

6-3
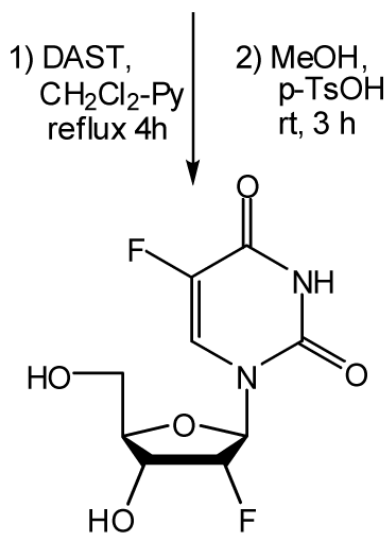

6-5

Scheme 6. 


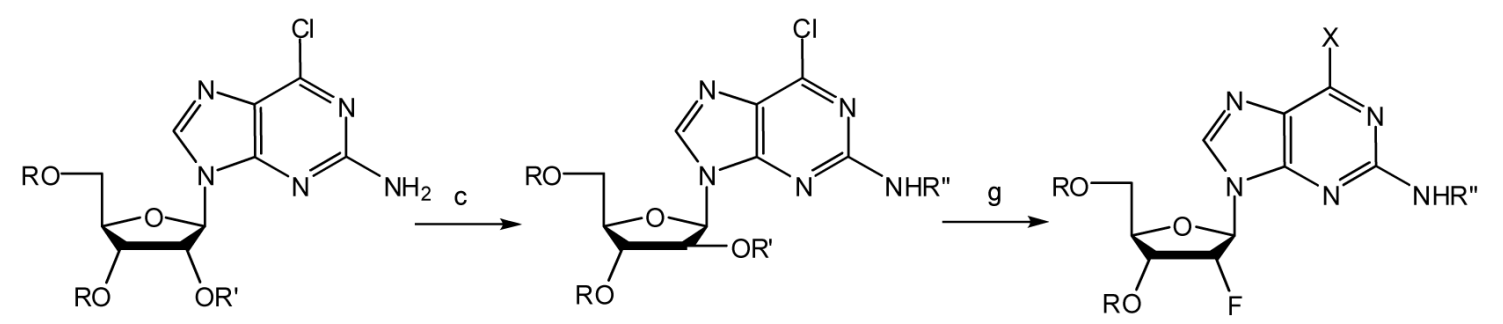

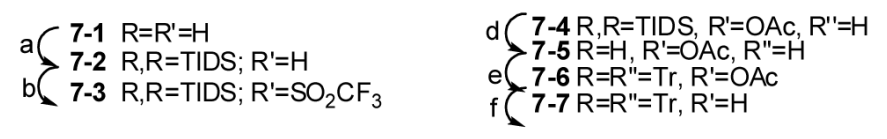

$7-8 \mathrm{R}=\mathrm{R}=\mathrm{Tr}, \mathrm{X}=\mathrm{Cl}$ Ref. 20

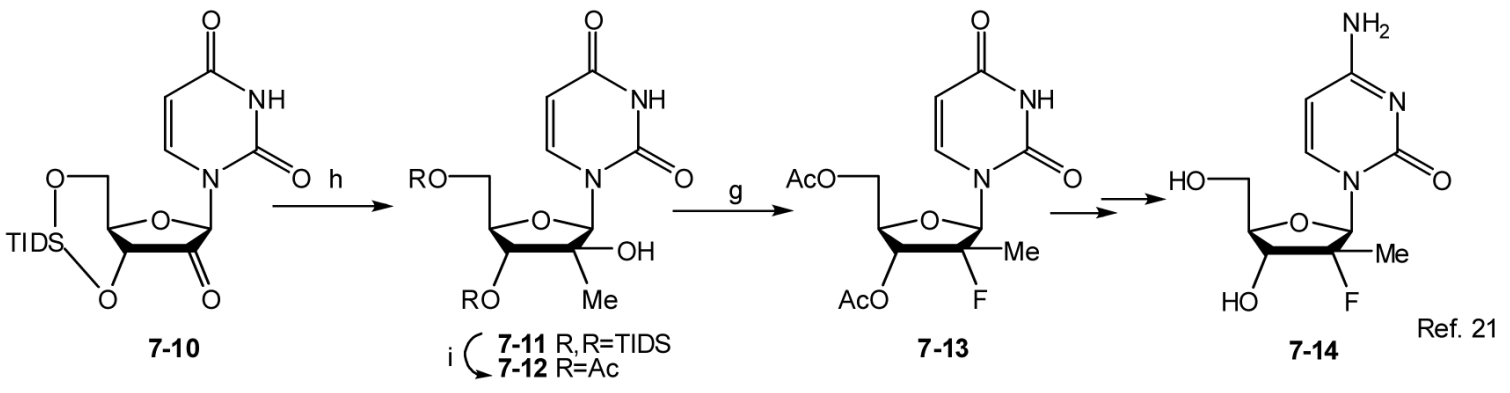

(a) TIDS-Cl 2 , imidazole, DMF; (b) TfCl, Et 3 N, DMAP, THF; (c) NaOAc, DMF; (d) TBAF/HOAc; (e) TrCl, Py; (f) $\mathrm{NH}_{3}-\mathrm{MeOH}$; (g) DAST; (h) MeLi, THF; (i) i-TBAF/HOAc; ii- $\mathrm{Ac}_{2} \mathrm{O}, \mathrm{Et}_{3} \mathrm{~N}$

Scheme 7. 


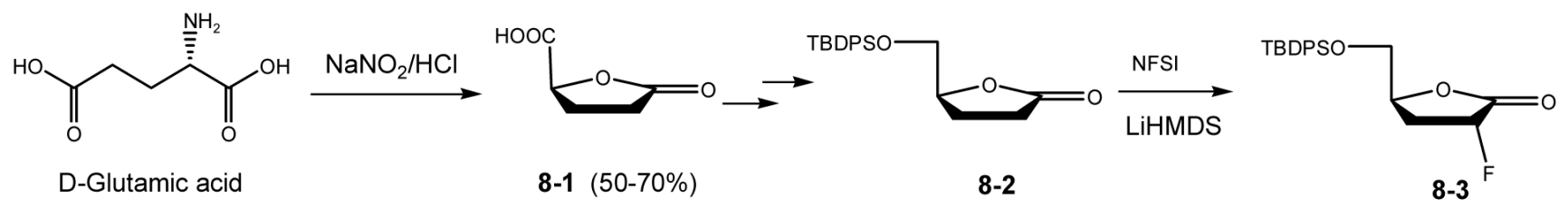

Scheme 8. 
<smiles>[X]c1cn(C2CO[C@H](CO)[C@@H](O)C2)c(=O)[nH]c1=O</smiles>

FIAU, $X=1$

FMAU, $X=M e$

FEAU, $X=E t$

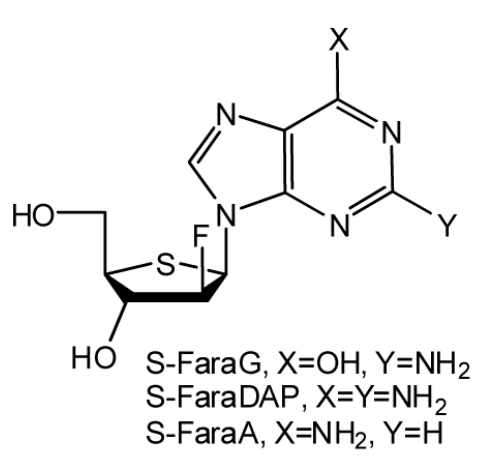<smiles>Cc1cn(CCO[C@H]2C[C@H](O)[C@@H](CO)O2)c(=O)[nH]c1=O</smiles>

L-FMAU<smiles>Cc1cn(C2CCC(O)[C@@H]2CO)c(=O)[nH]c1=O</smiles>

S-FMAU<smiles>Cc1cn(C2CCC(O)[C@H](CO)S2)c(=O)[nH]c1=O</smiles>

L-S-FMAU

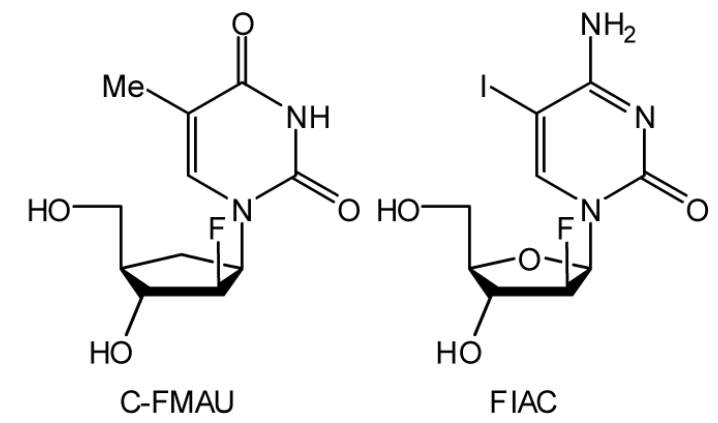

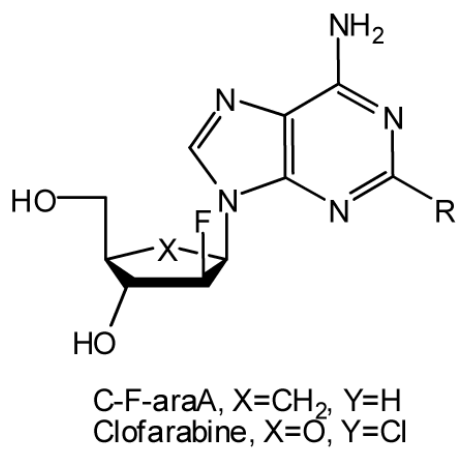

Figure 2. 

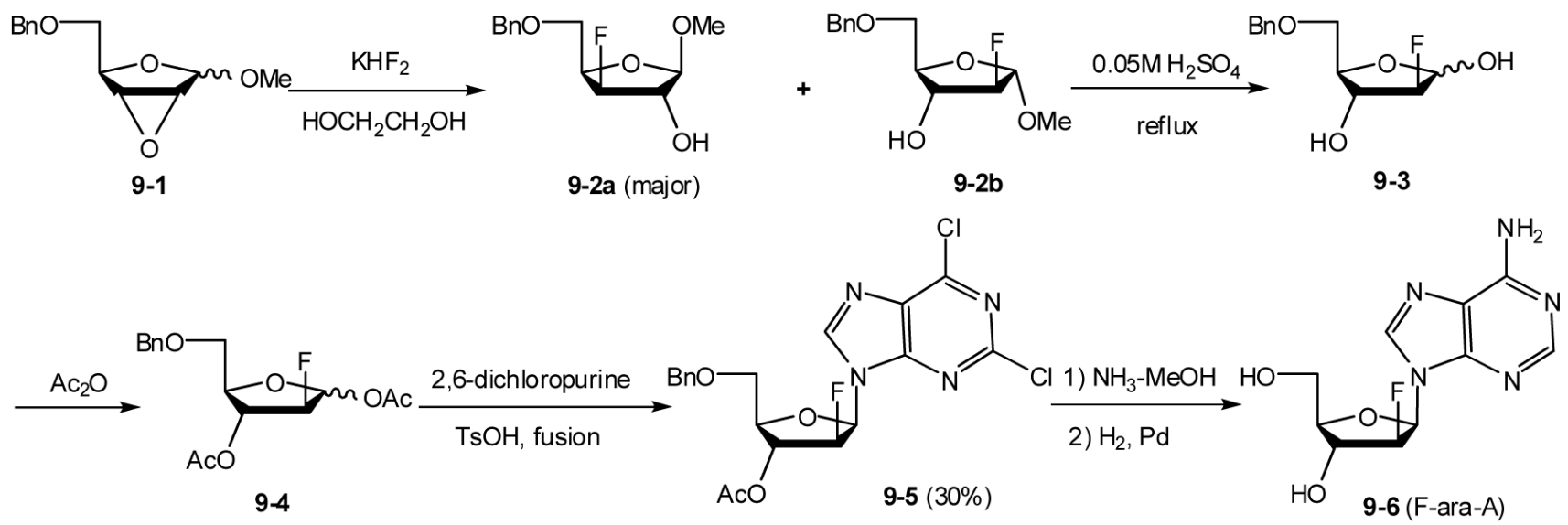

Scheme 9. 

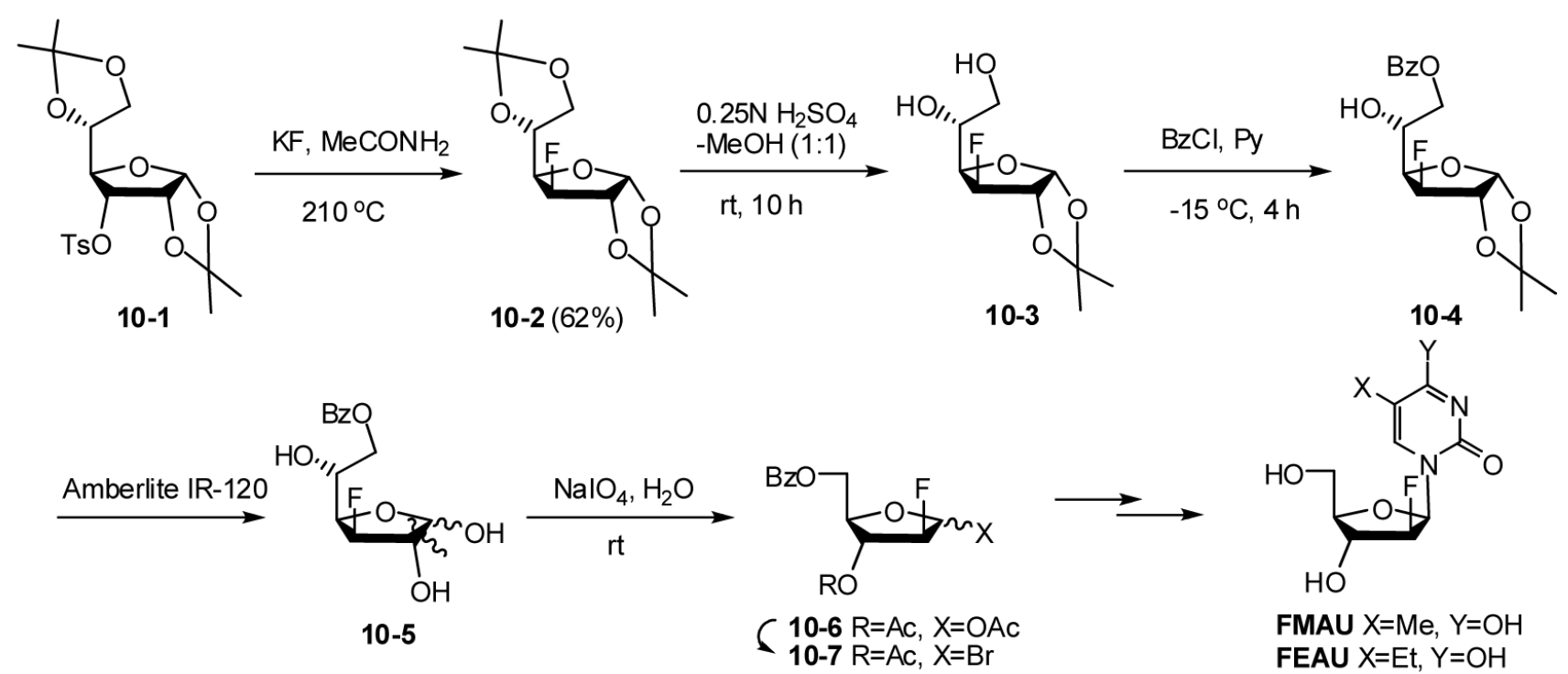

FMAU $X=\mathrm{Me}, Y=\mathrm{OH}$ FEAU $X=E t, Y=\mathrm{OH}$ FIAC $X=I, Y=\mathrm{NH}_{2}$

Scheme 10. 

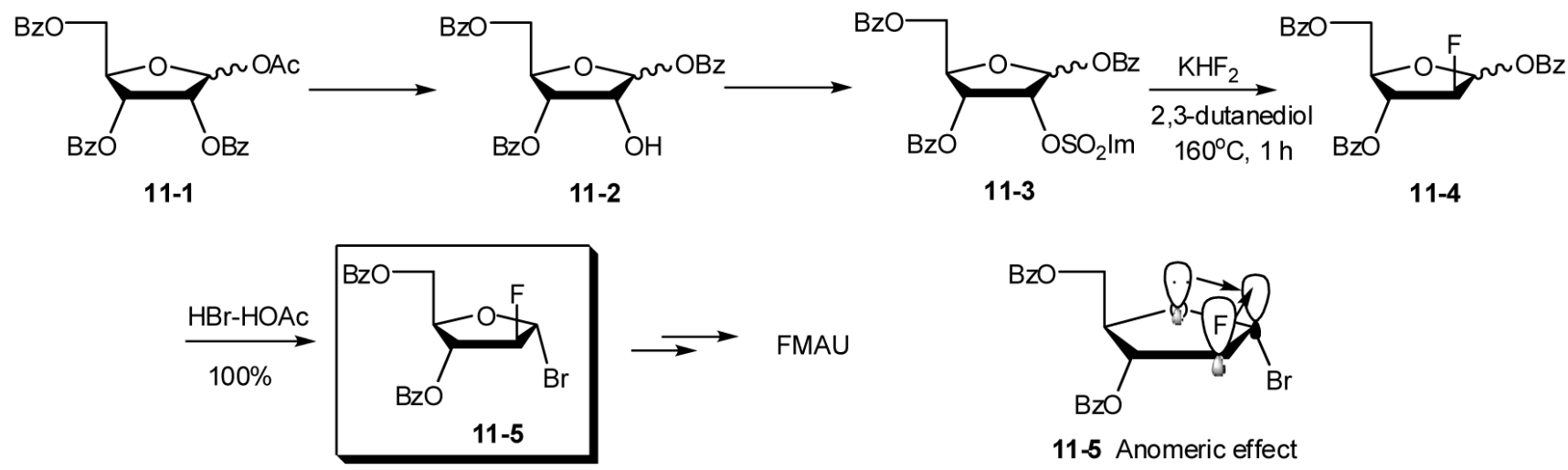

11-5 Anomeric effect

Scheme 11. 
<smiles>Oc1ncnc2c1ncn2C1CCCC1COCc1ccccc1</smiles>

12-1

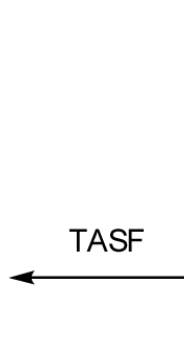<smiles>[R6]CC1O[C@@H](n2cnc3c([X])ncnc32)[C@H]([O])[C@@H]1[R]</smiles>

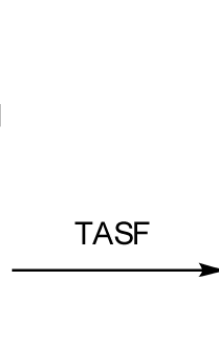

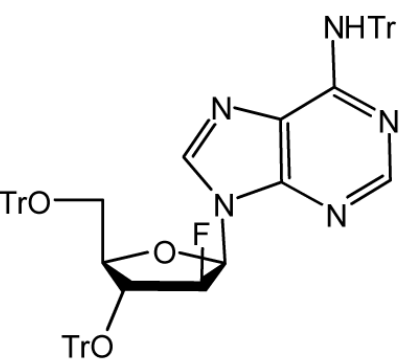

12-2 a, R=Bn, $X=O H$;

b, $\mathrm{R}=\mathrm{Tr}, \mathrm{X}=\mathrm{NHTr}$

$12-3(30 \%)$

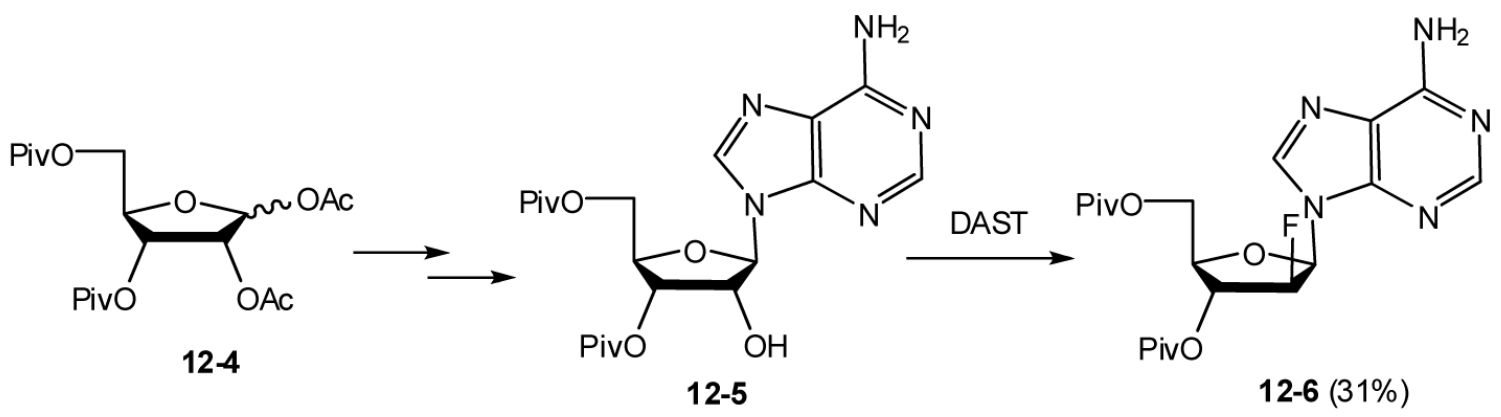

Scheme 12. 


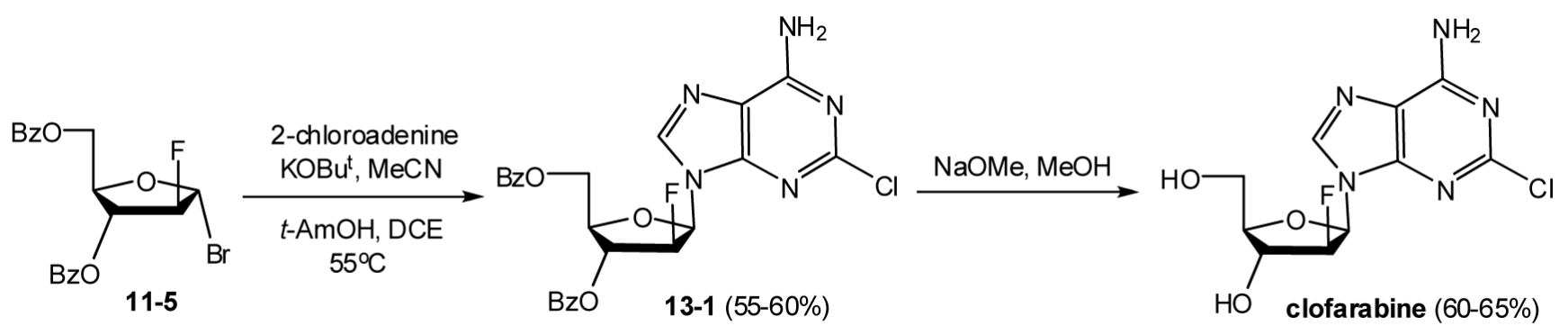

Scheme 13. 
<smiles>OC1C(O)[C@@H]2OC[C@H]1C2O</smiles>

L-arabinose<smiles>Cc1cn(C2CC3CC2CC3O)c(=O)[nH]c1=O</smiles>

L-FMAU (Clevudine)

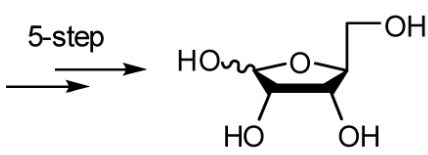

L-ribose

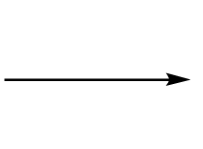

14-1
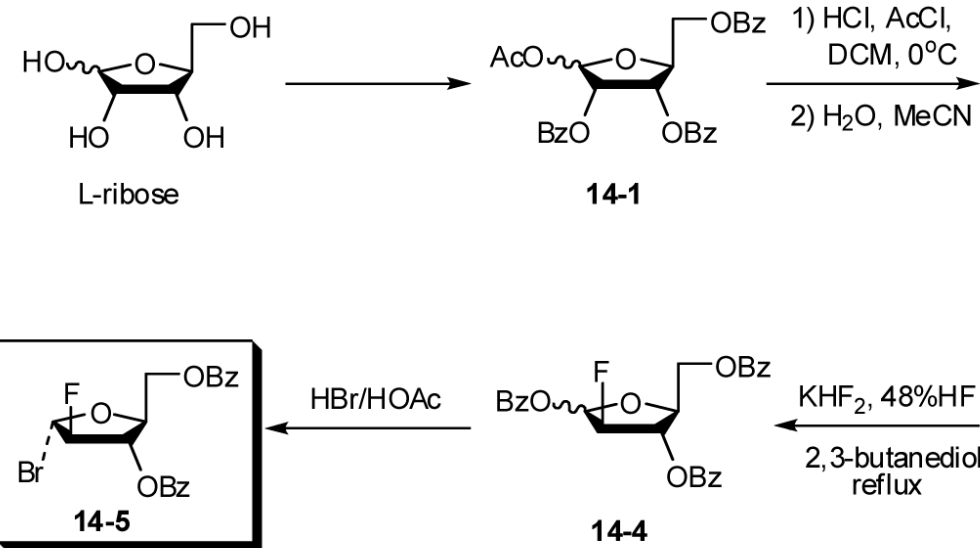

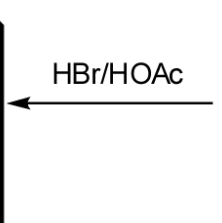

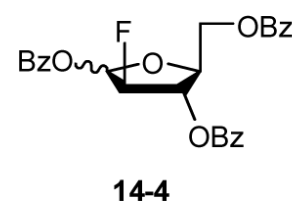

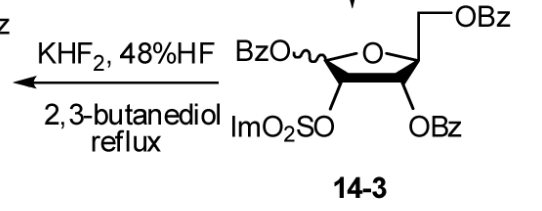

Scheme 14. 

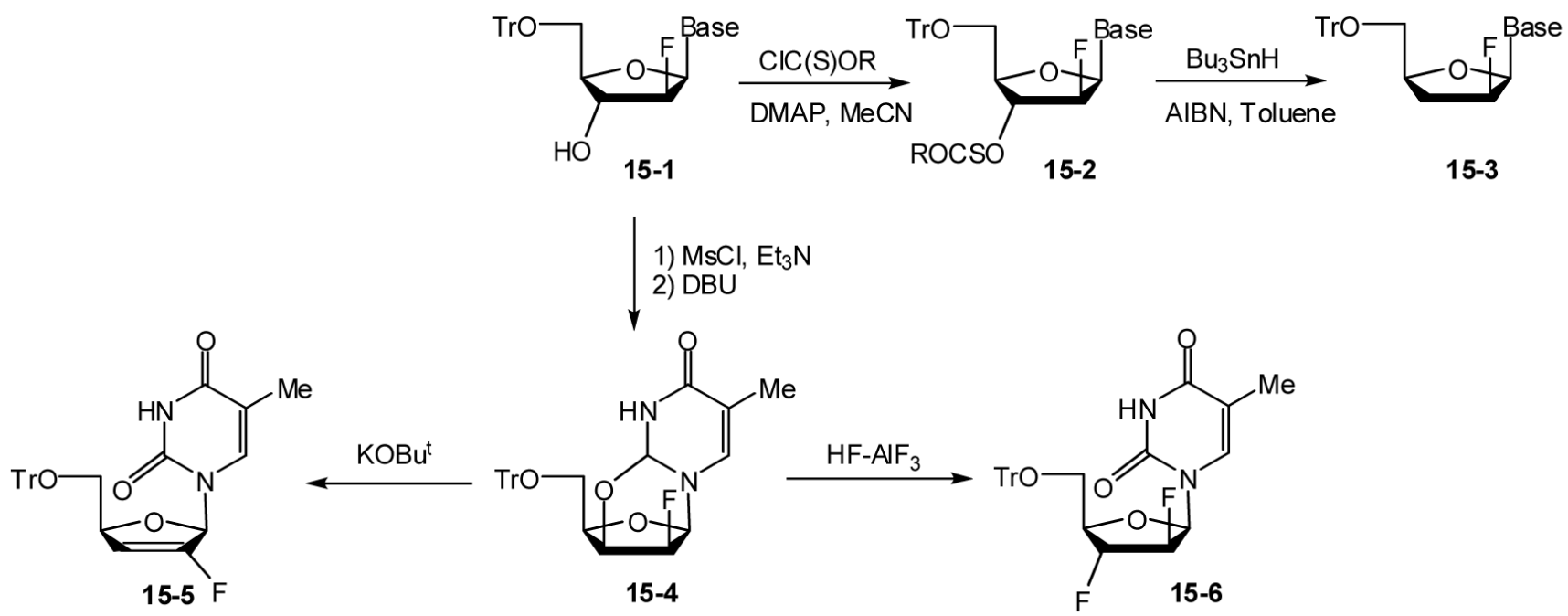

Scheme 15. 

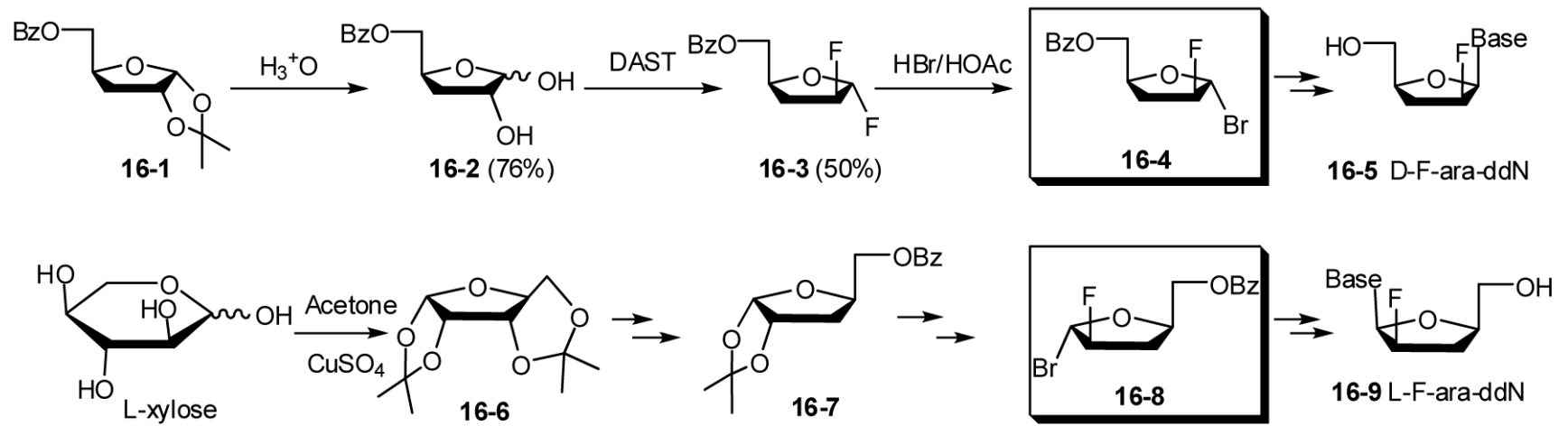

Scheme 16. 


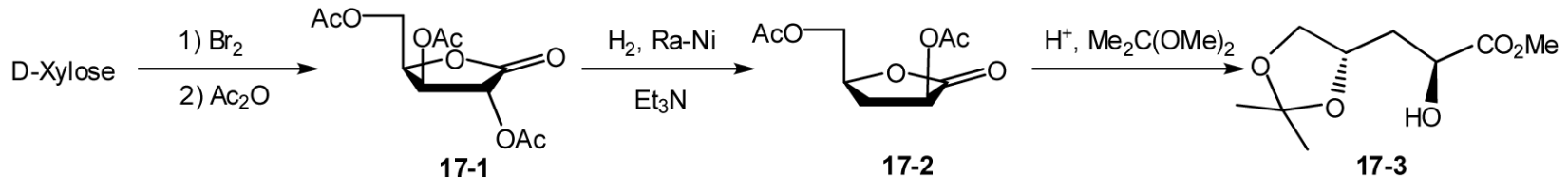

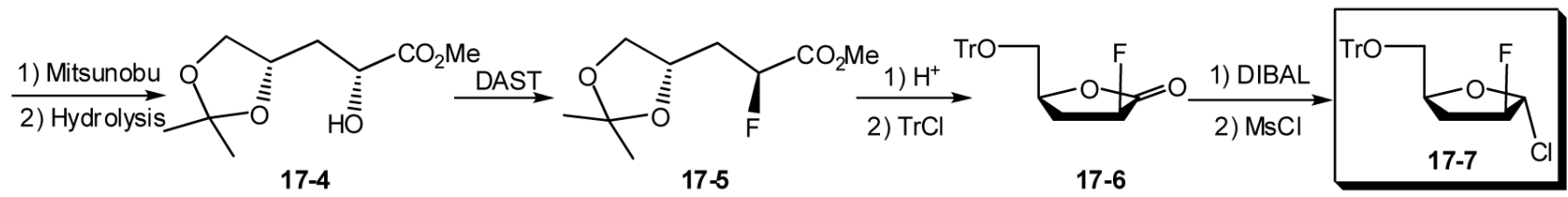

Scheme 17. 

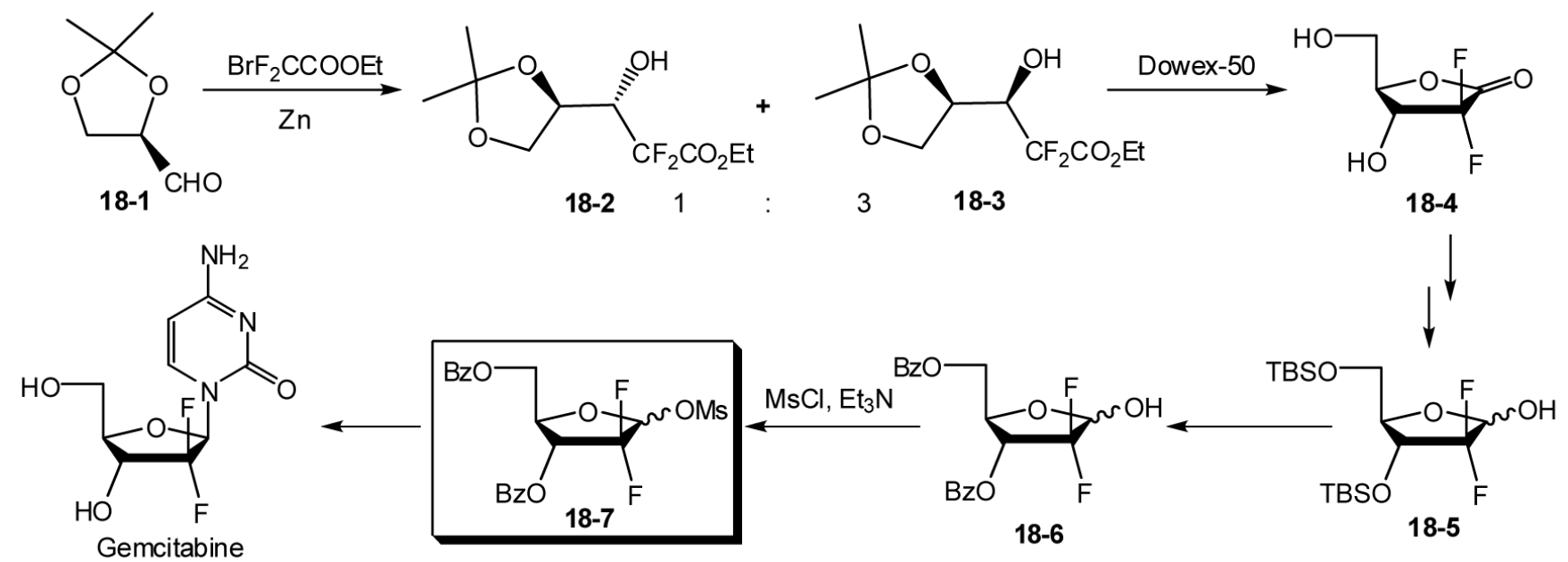

Scheme 18. 

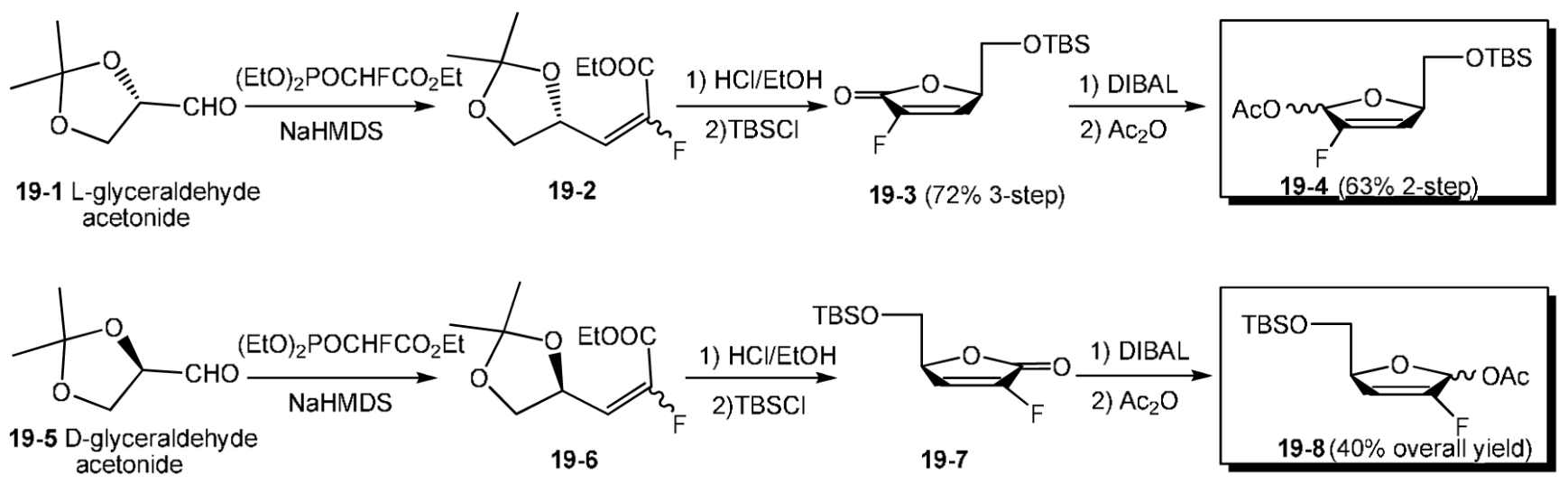

Scheme 19. 

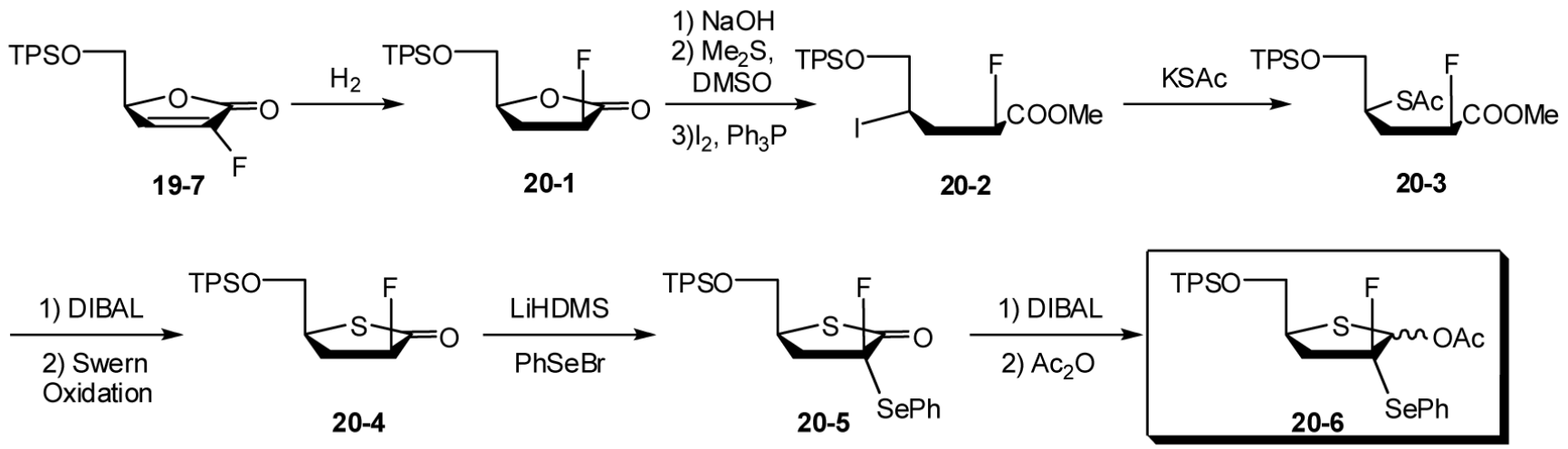

Scheme 20. 


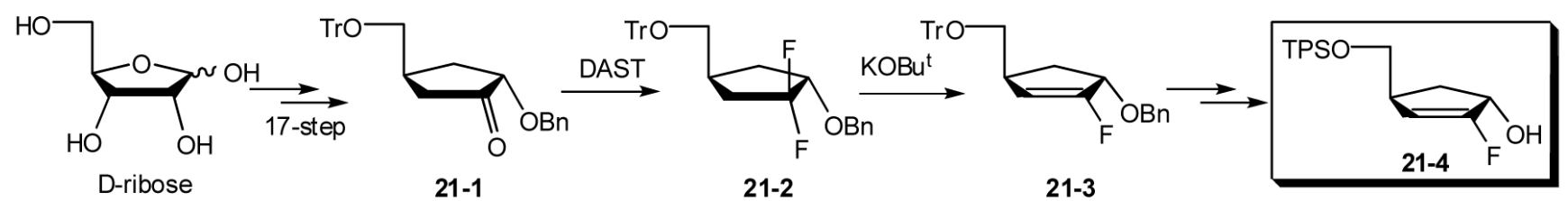

Scheme 21. 
<smiles></smiles>

FddU, $\mathrm{R}=\mathrm{H}$

FddClU, $\mathrm{R}=\mathrm{Cl}$

$\mathrm{FLT}, \mathrm{R}=\mathrm{Me}$

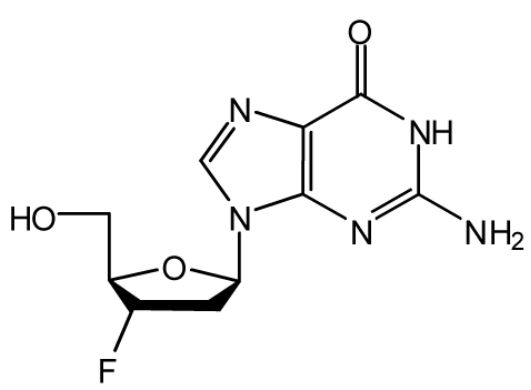

FddG (FLG)<smiles>Nc1ccn([C@@H]2C[C@@H](F)[C@@H](CO)O2)c(=O)n1</smiles>

L-FddC

Figure 3. 


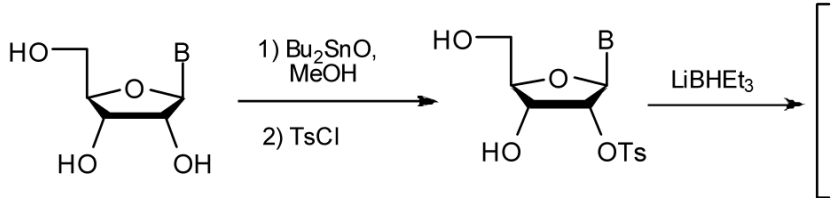

22-1 B=A, G etc

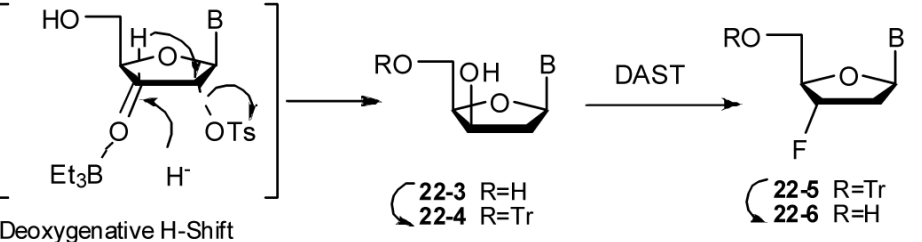

Scheme 22. 

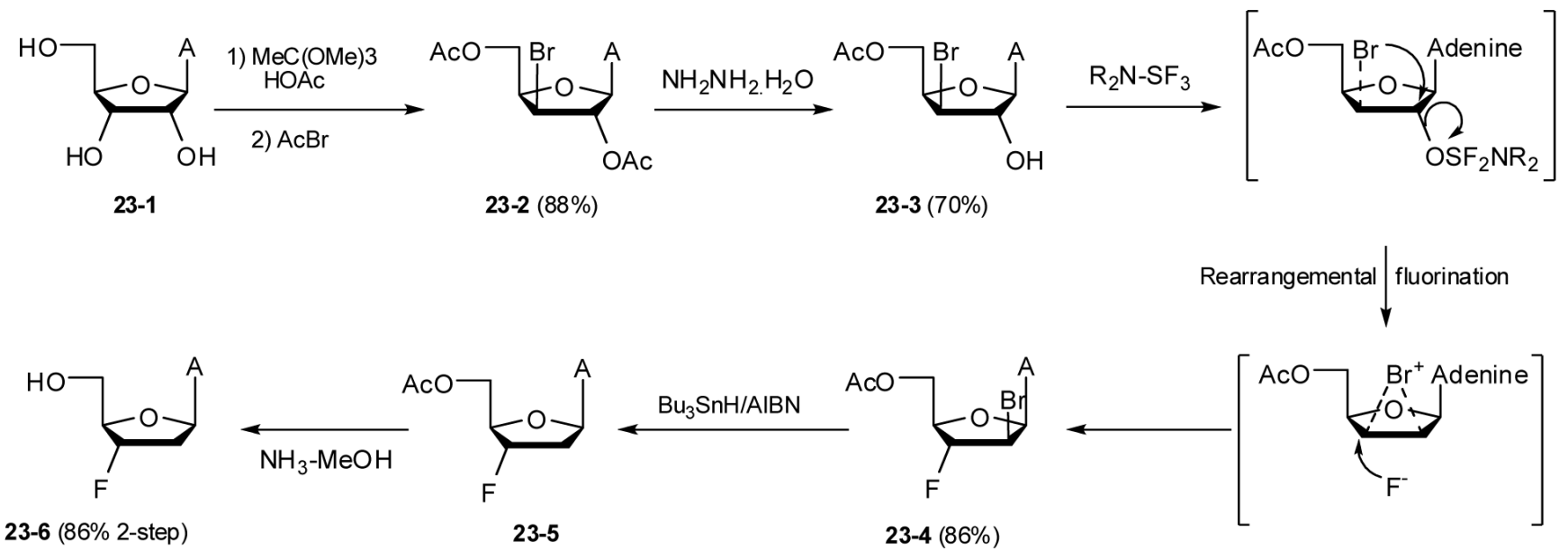

Scheme 23. 

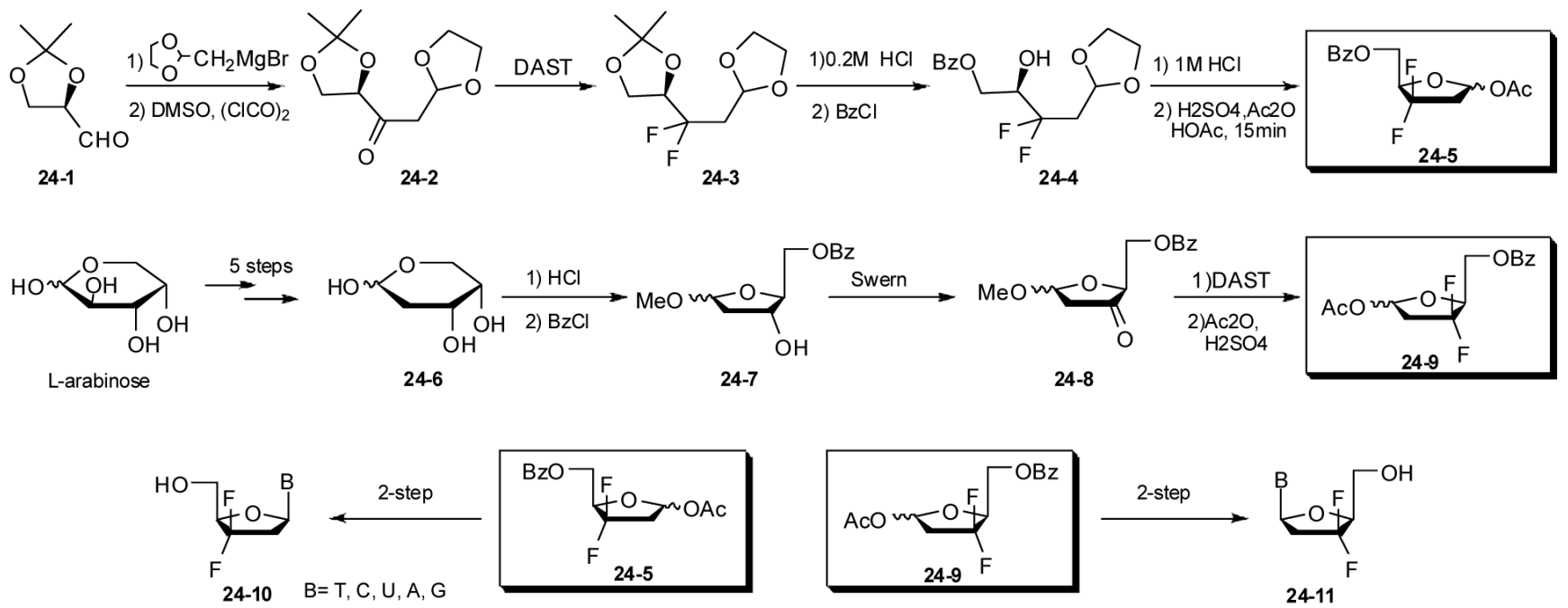

Scheme 24.

J Fluor Chem. Author manuscript; available in PMC 2009 September 1. 


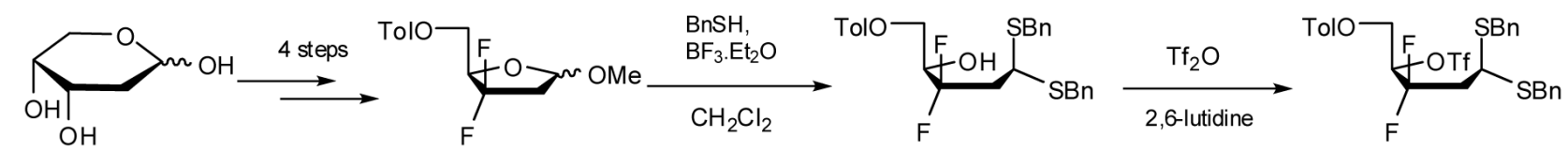

2-Deoxy-D-ribose

25-1

25-2

25-3

$\downarrow \begin{aligned} & \mathrm{BaCO}_{3} \\ & \mathrm{TBAl}\end{aligned}$

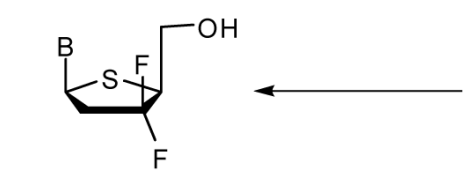

25-6 $B=U, T, C, A, G$
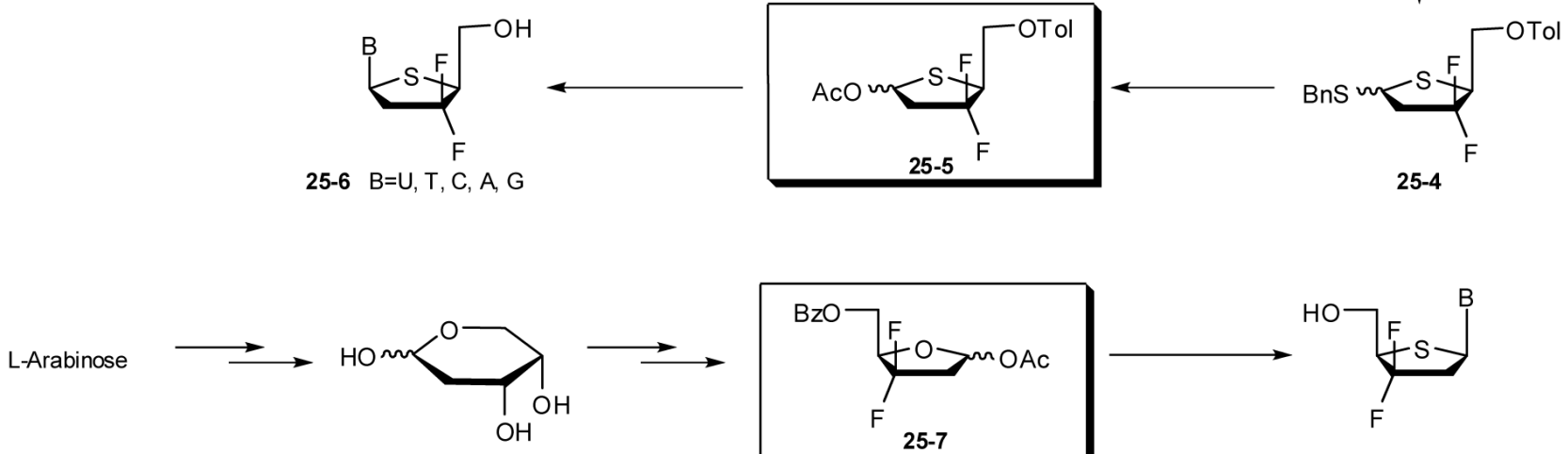

2-Deoxy-L-ribose
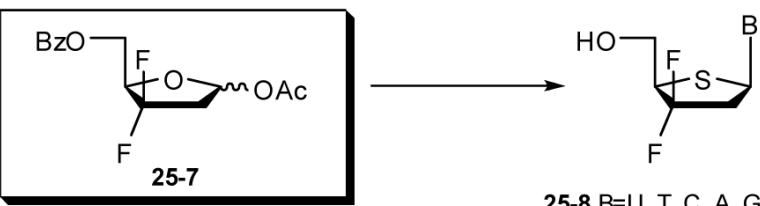

25-8 $B=U, T, C, A, G$

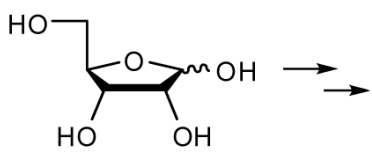

D-Ribose

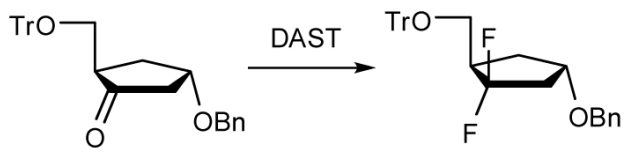

25-9

25-10

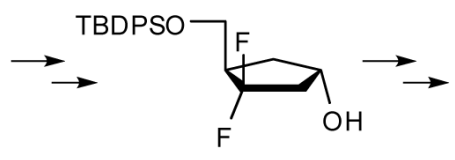

25-11

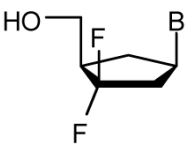

25-12 $B=U, T, C, A, G$

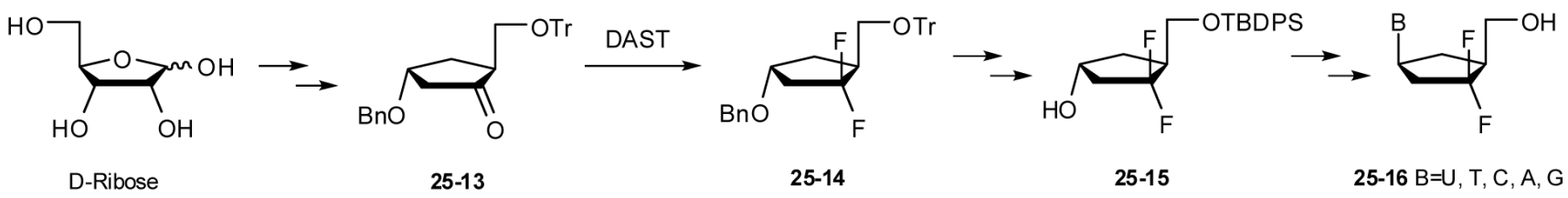

Scheme 25 .

J Fluor Chem. Author manuscript; available in PMC 2009 September 1. 


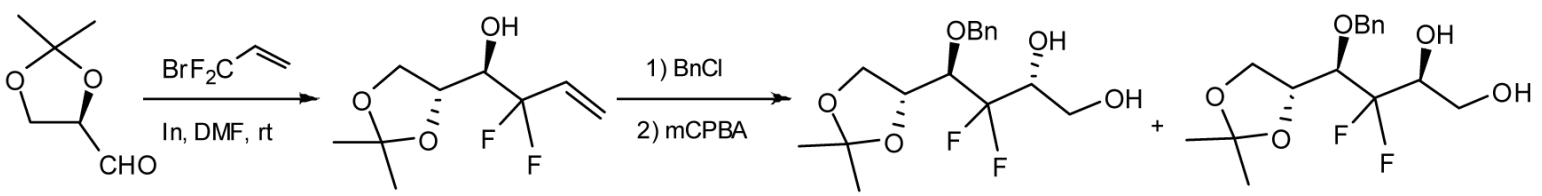

24-1

26-1 (80\%)

26-2

26-3
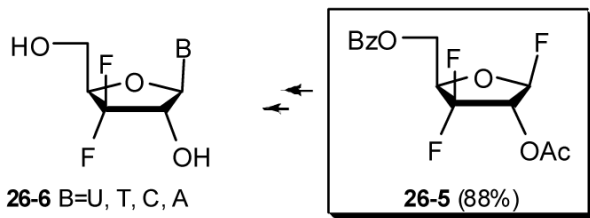

Deoxy-Fluor
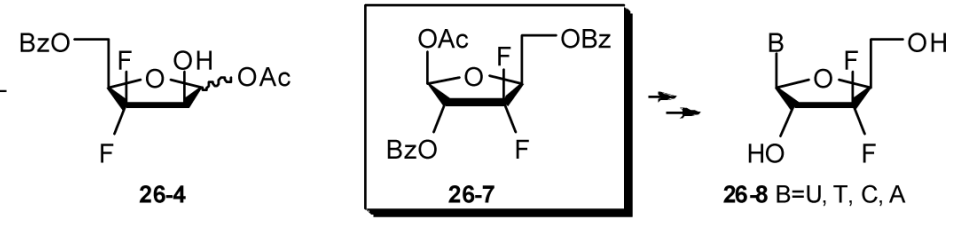

Scheme 26. 

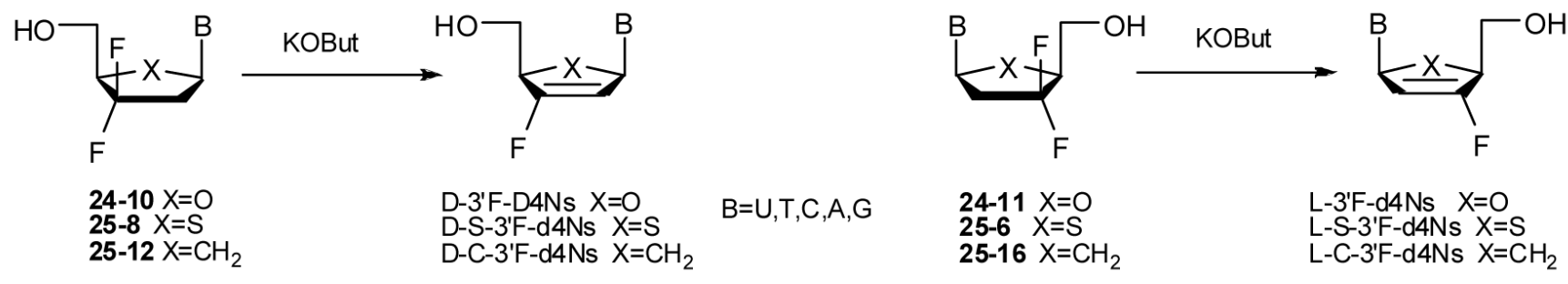

$24-10 X=O$
$25-8 X=S$ D-S-3'F-d4Ns $X=S$ D-C-3'F-d4Ns $X=\mathrm{CH}_{2}$

$24-11 X=O$
$25-6 \quad X=S$

25-6
25-16

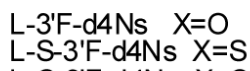
L-S-3'F-d4Ns $X=S$
L-C-3'F-d4Ns $X=\mathrm{CH}_{2}$

Scheme 27. 


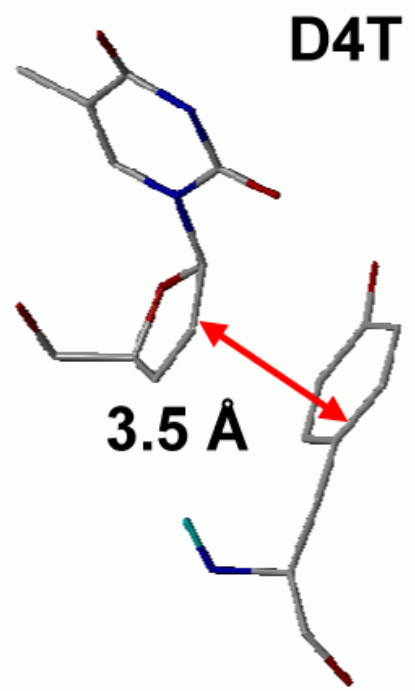

2'Fd4C

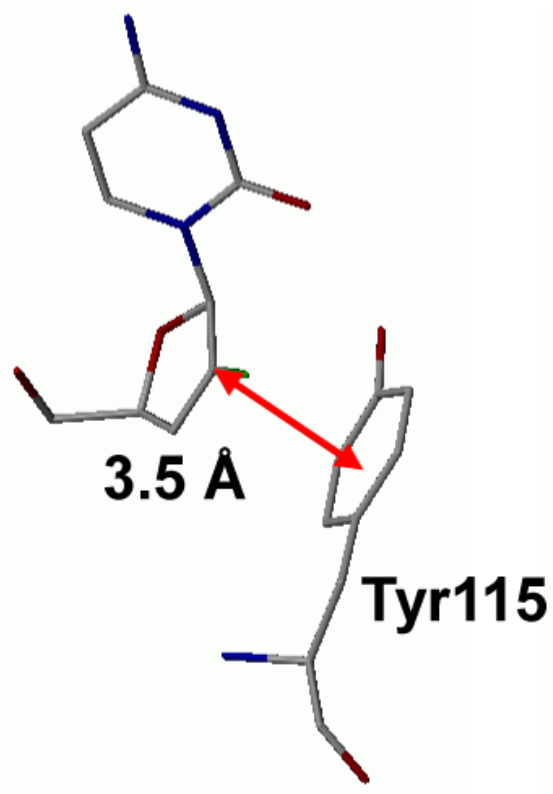

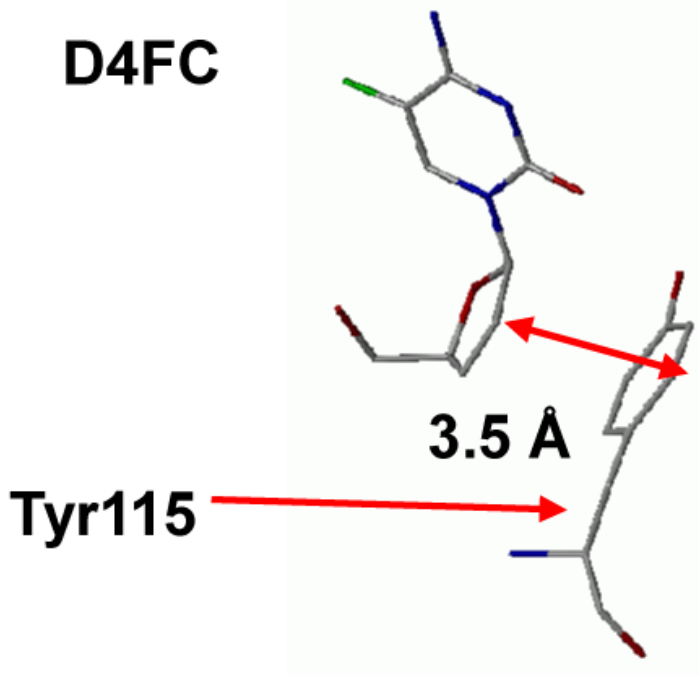

2'F-4'Sd4C

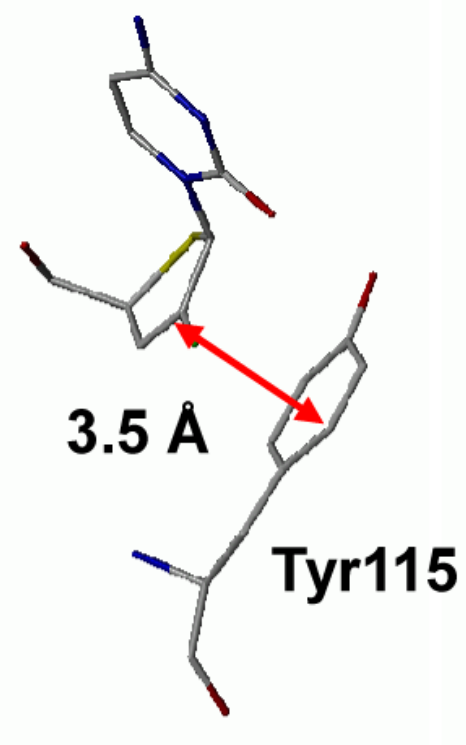

Carbovir

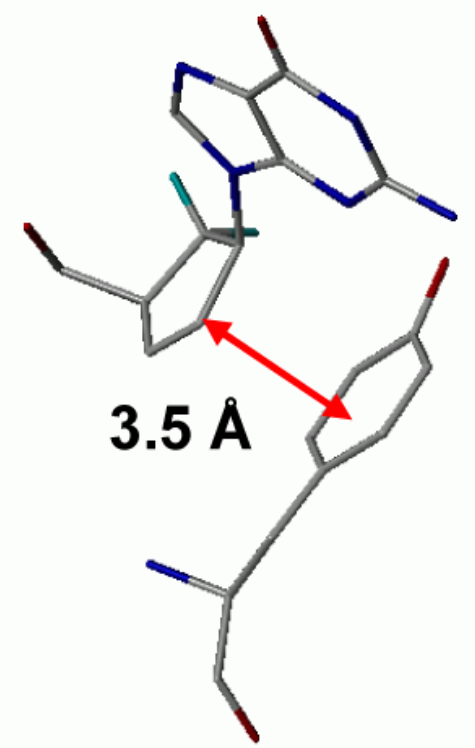

Figure 4a.

$2^{\prime}, 3^{\prime}$-double bonds of (D4T, D4FC, 2'Fd4C, 2'F-4'Sd4C and Carbovir) are separated from the aromatic side chain of Tyr 115 by $3.5 \AA$ situated in parallel by the hydrophobic $\pi-\pi$ interaction. 


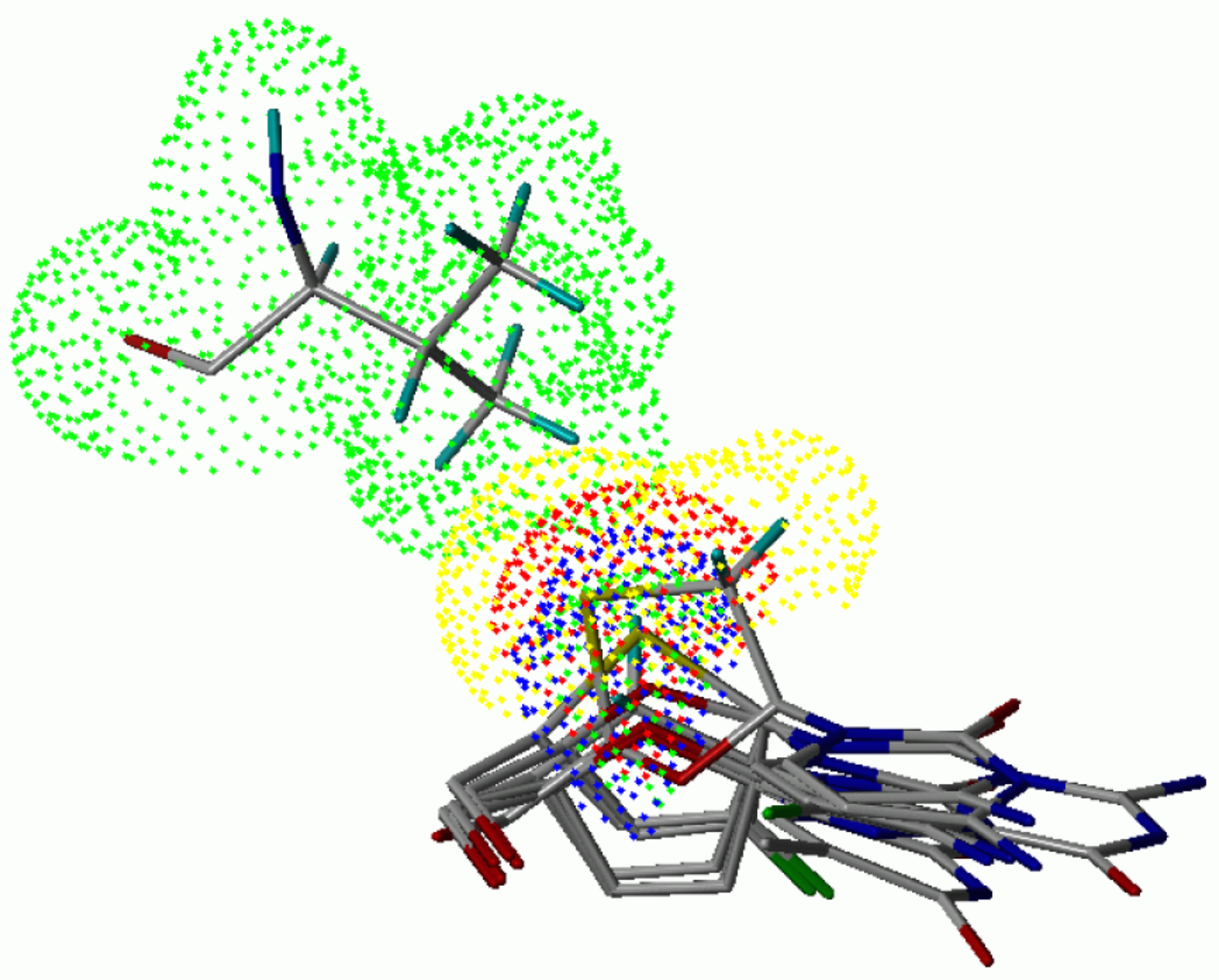

Figure 4b.

No steric hindrance is found between 4'- $\mathrm{CH}_{2}$ group (blue) of carbovir with Val184. However, $2^{\prime} \mathrm{F}-4$ 'Sd4C with 4'-sulfur (red) experiences steric hindrance. L-Configured 3TC (yellow) also has steric hindrance with Val184. 
(a)

(c)

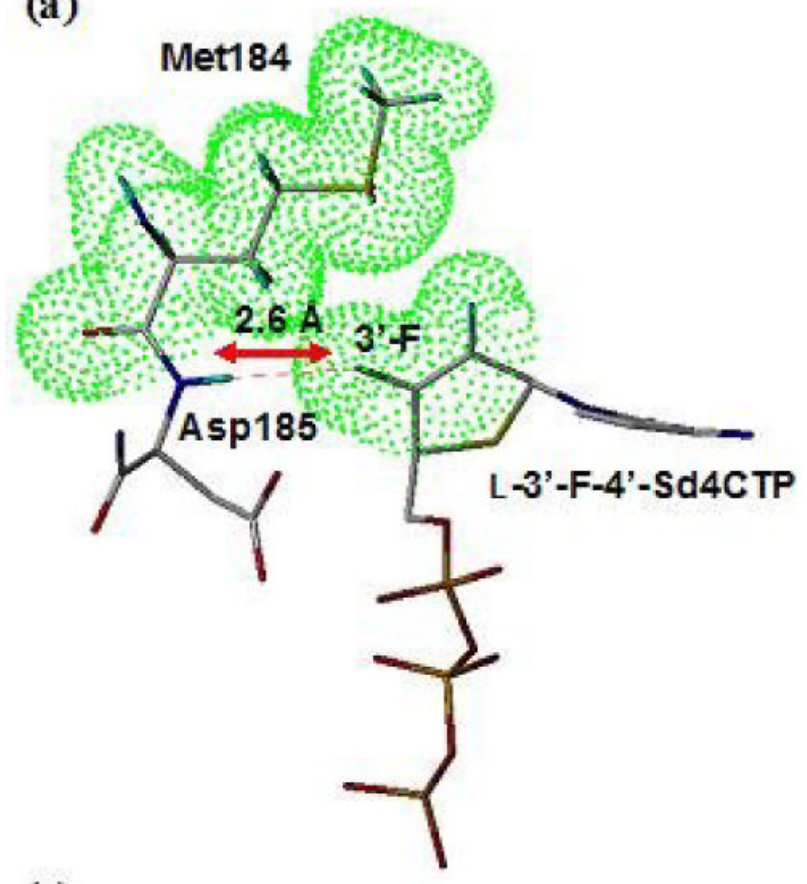

(b)
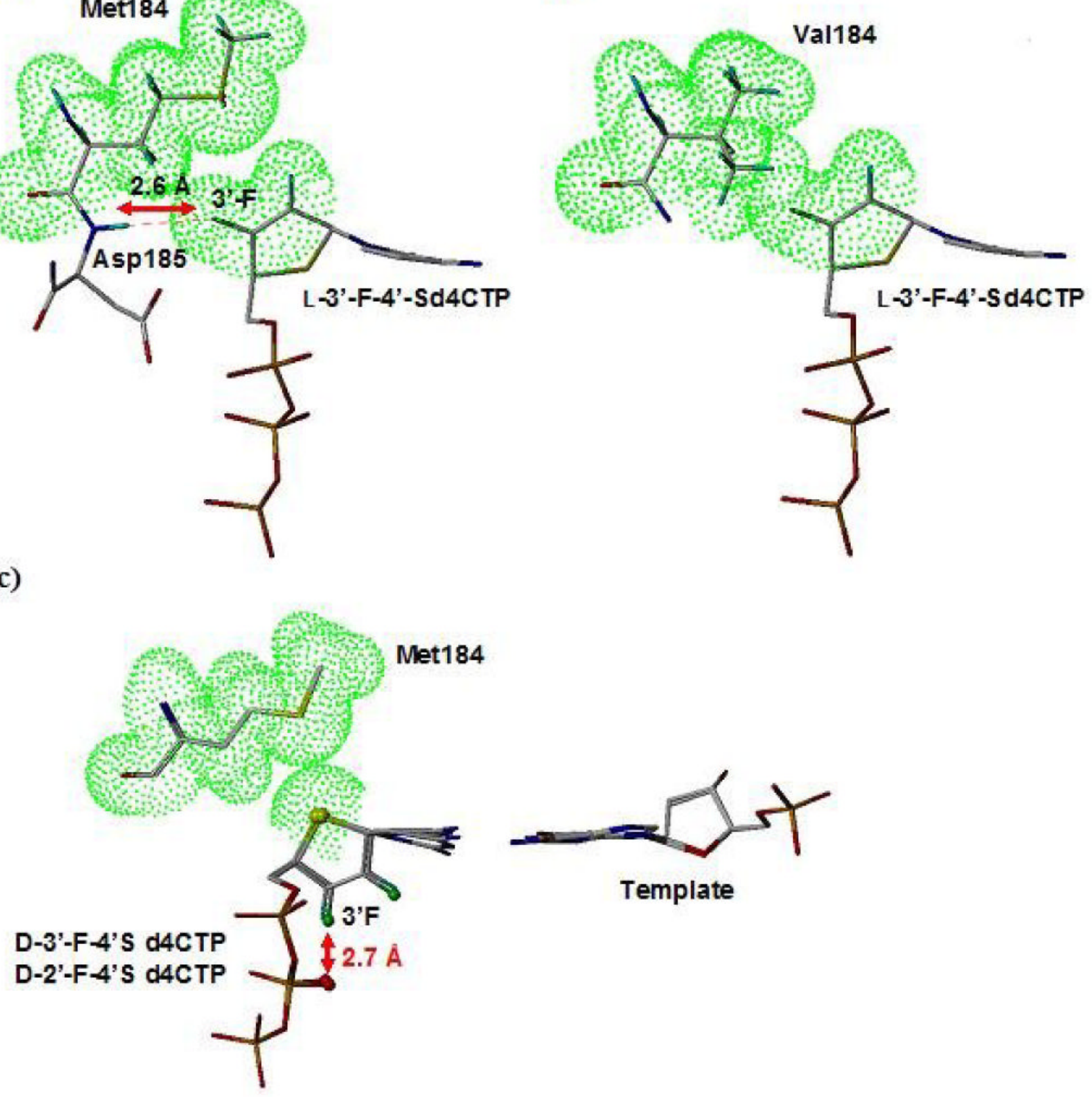

Figure 5.

a) L-3'F-4'Sd4C binds in the active site without steric hindrance with Met184. 3'-F showing H-bond with NH of Asp185. b) L-3'F-4'Sd4C in M184V HIV-1-RT, showing steric hindrance with V184 c) 3'-F group of D-3'F-4'Sd4C showing intramolecular interaction with $\beta$-phosphate causing unfavourable binding conformation 


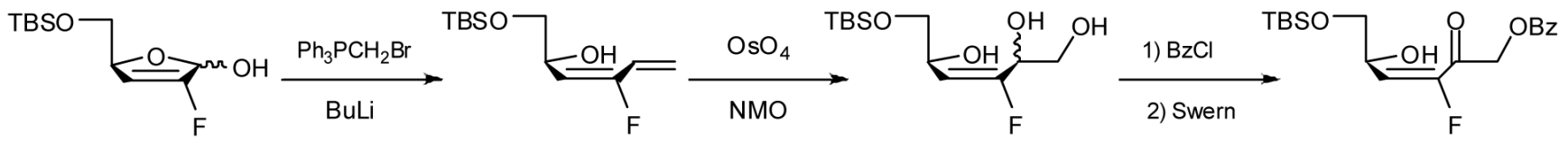
28-1

28-2

28-3
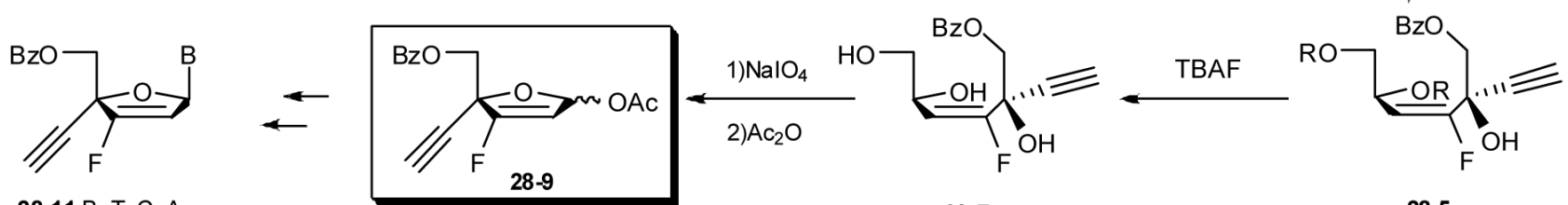

28-11 B=T, C, A

28-7

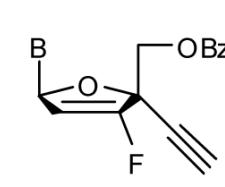

$\leftarrow$

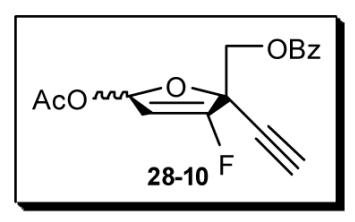

${ }_{2) \mathrm{Ac}_{2} \mathrm{O}}^{1) \mathrm{NalO}_{4} \mathrm{HO}}{ }_{\mathrm{F}}^{\mathrm{BzO}}$

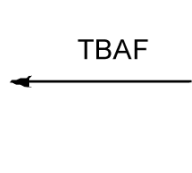

28-8
28-5

$+\quad \mathrm{R}=\mathrm{TBS}$

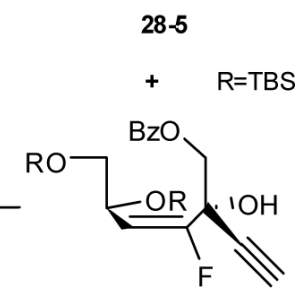

$28-6$

Scheme 28 . 


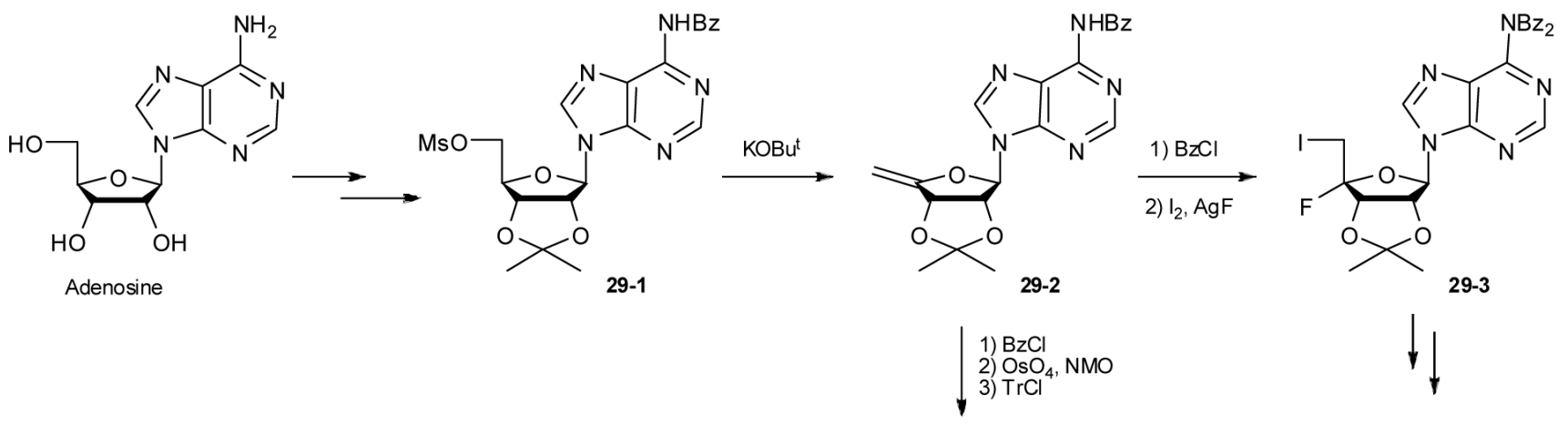

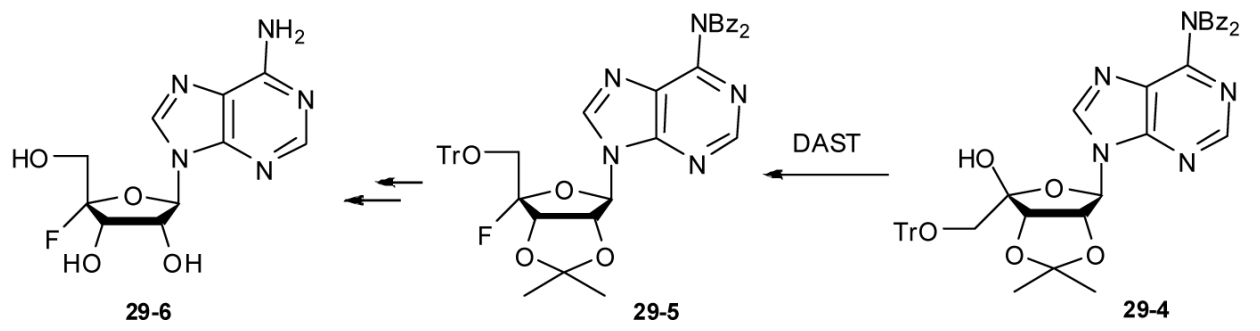

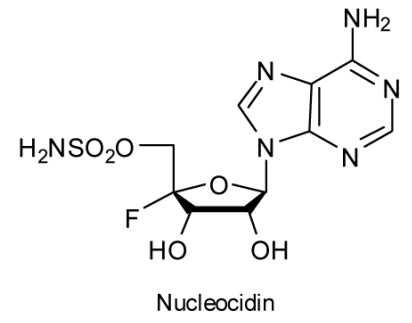

Scheme 29. 
<smiles>CCOC(=O)/C(F)=C\[C@@H]1COC(C)(C)O1</smiles>

19-6

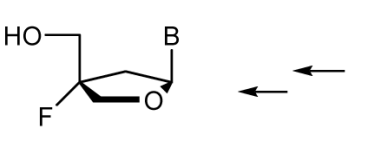

$30-6 B=C, A$

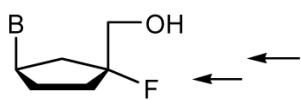

30-12 B=U, T, C, A, G

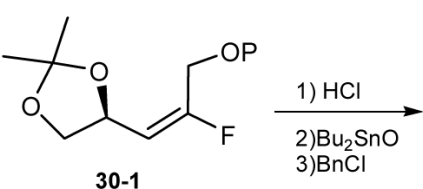

30-1

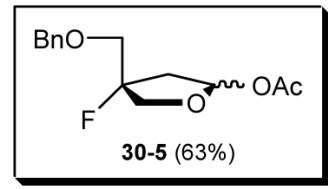

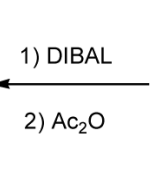<smiles>CCOC(C)=O</smiles><smiles>CCOC(=O)C[C@](F)(C=O)CBr</smiles><smiles>CCO</smiles>

30-4 (79\%)

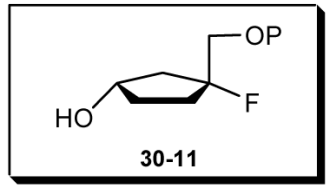

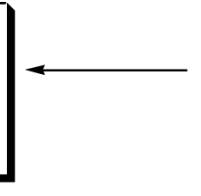

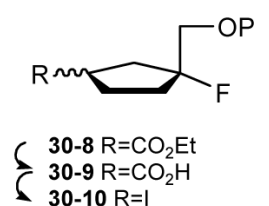

$30-9 \mathrm{R}=\mathrm{CO}_{2} \mathrm{H}$

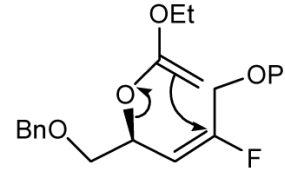

1,3-sigma shift

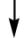

EtO<smiles>CCOC[C@](F)(/C=C/COc1ccccc1)CC(=O)OCC</smiles>

30-3 $(80 \%)$

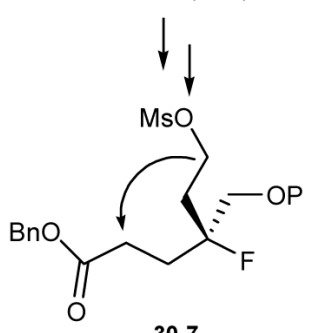

Scheme 30. 


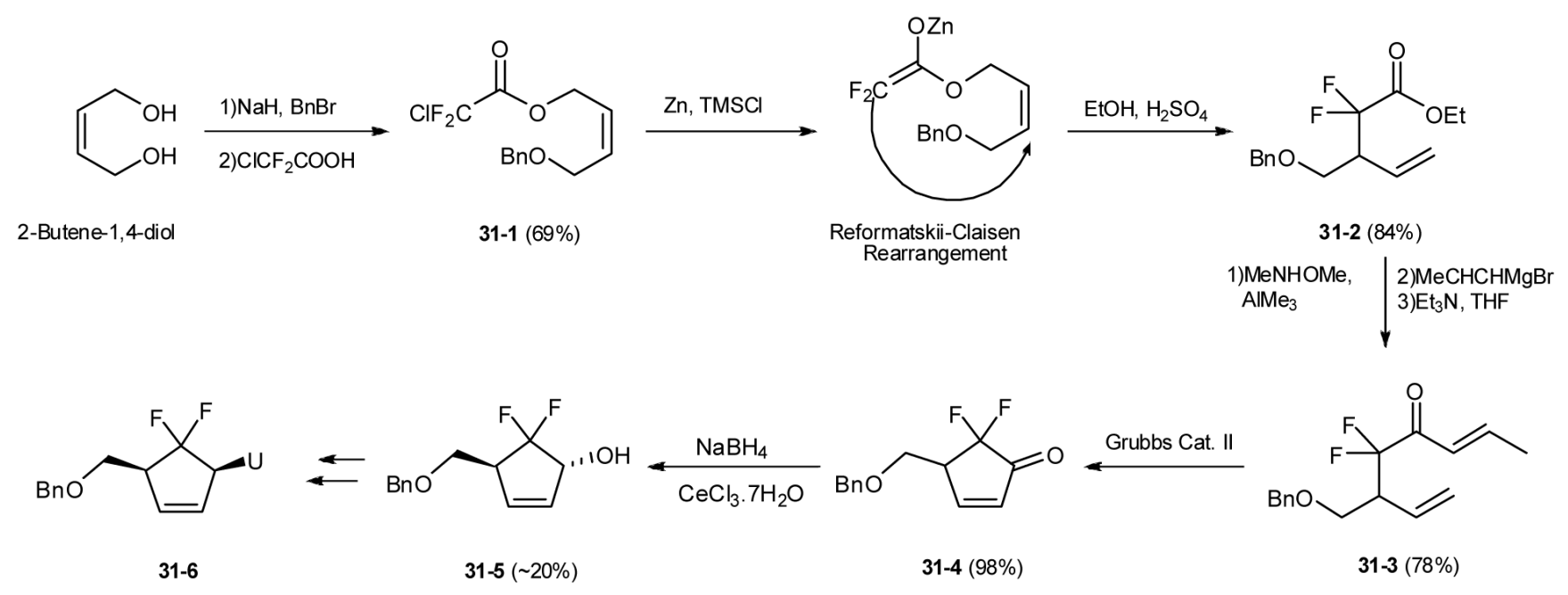

Scheme 31. 


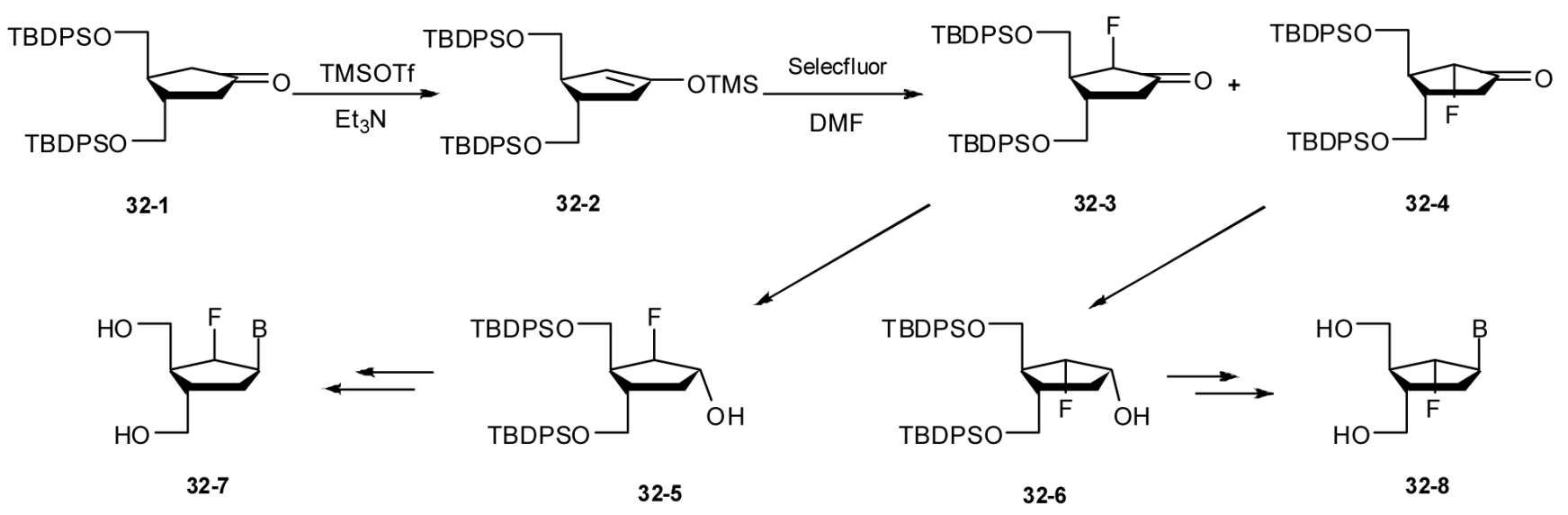

Scheme 32. 


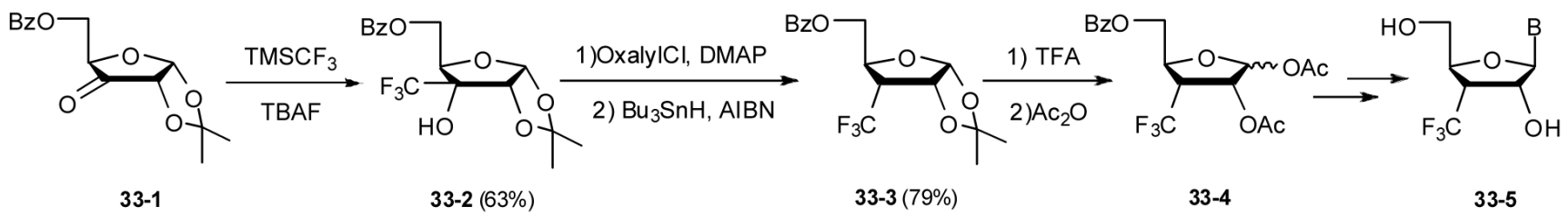

Scheme 33. 

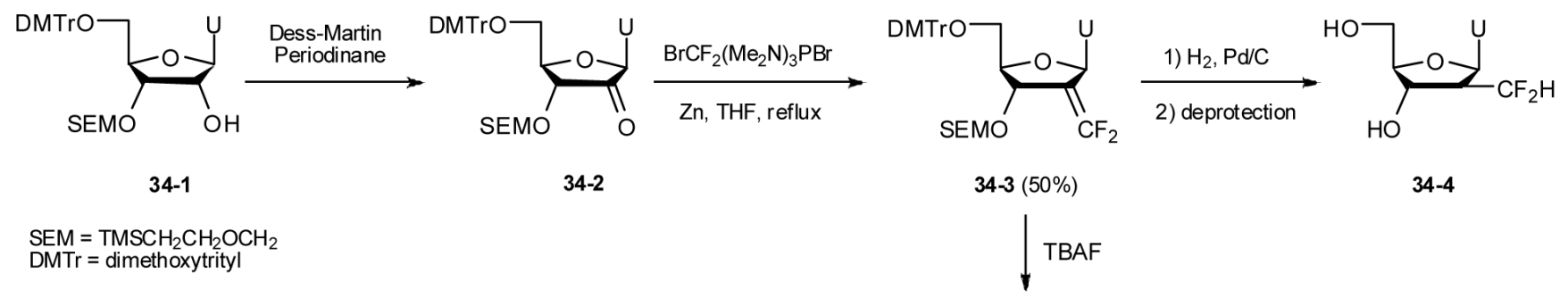

$\mathrm{SEM}=\mathrm{TMSCH}_{2} \mathrm{CH}_{2} \mathrm{OCH}_{2}$

$34-2$

$\mathrm{DMT} r=$ dimethoxytrityl

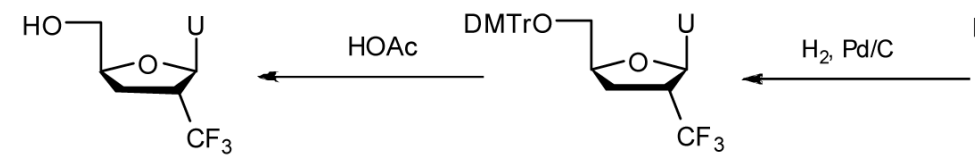

34-8 (69\% for 2-step)
34-7

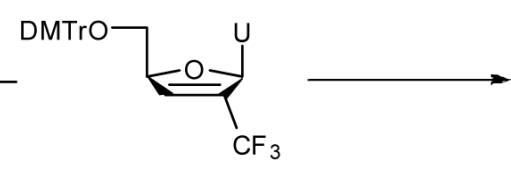

34-5 (50\%)

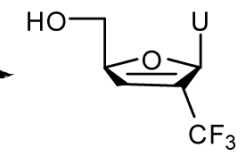

$34-6(70 \%)$

Scheme 34. 


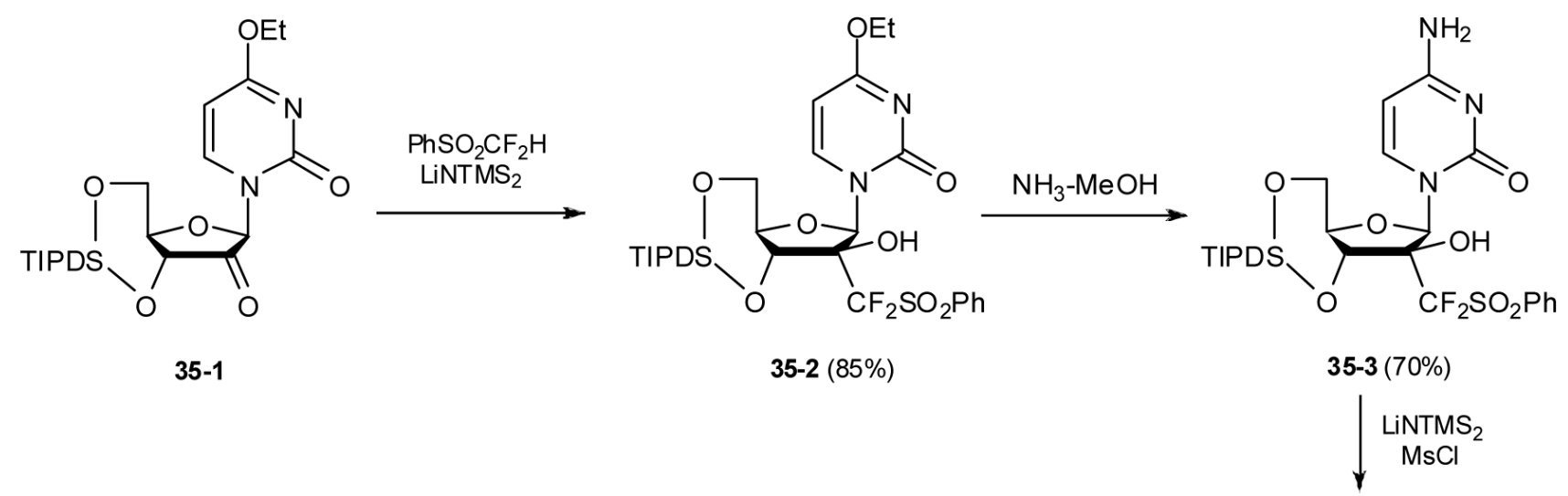

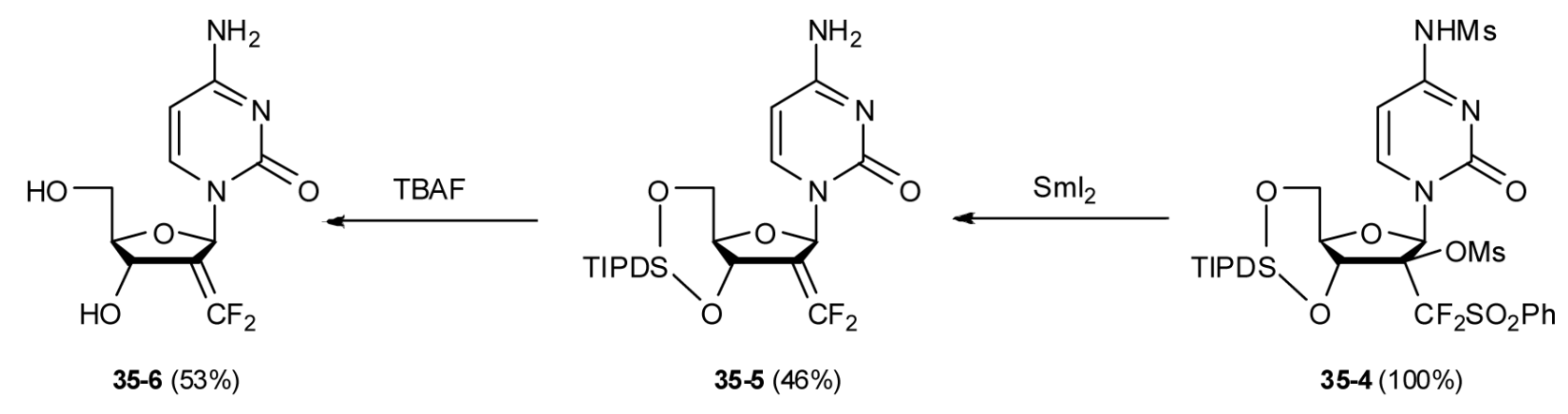

Scheme 35. 


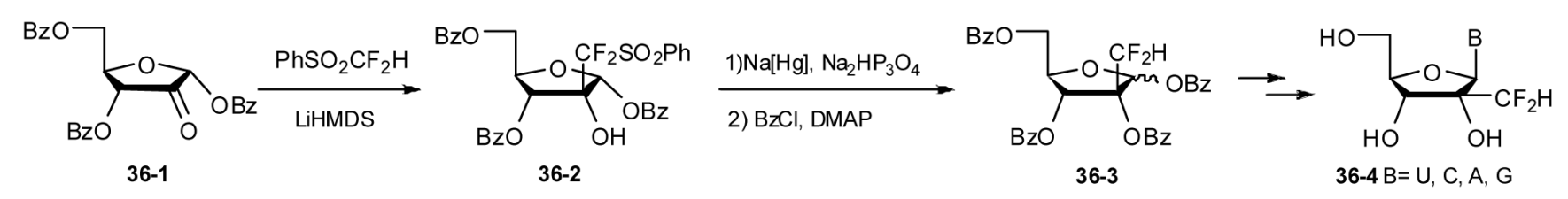

Scheme 36. 


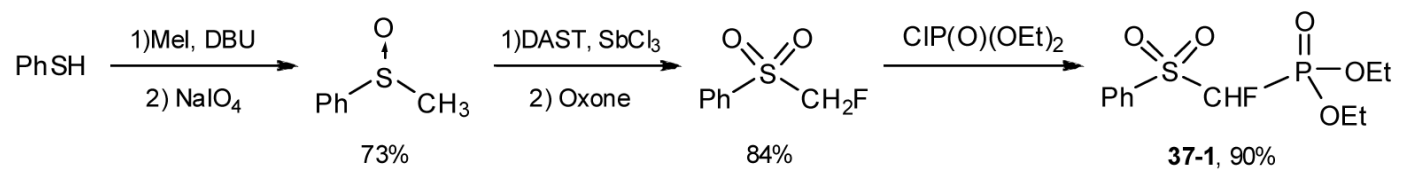

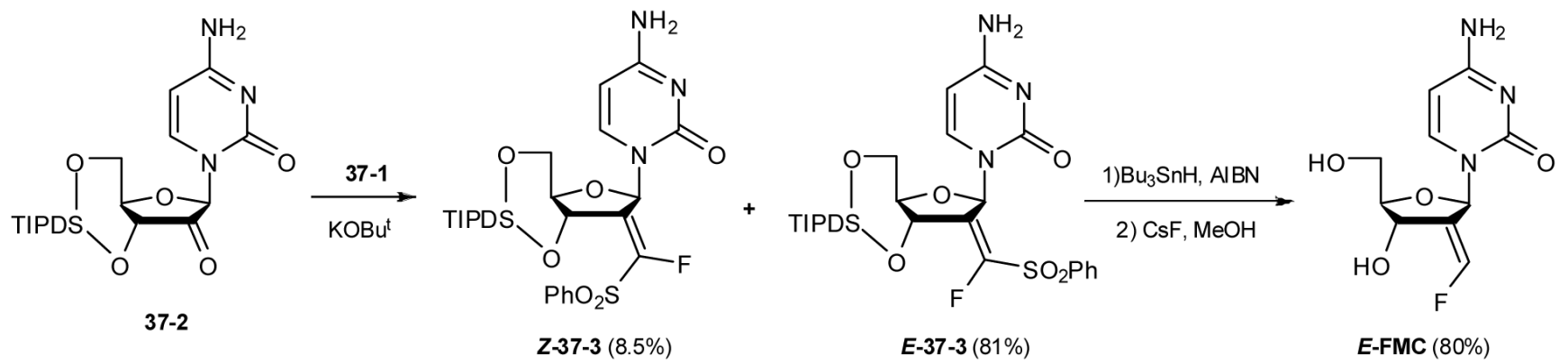

Scheme 37. 
<smiles>O=c1[nH]cc(F)c(=O)[nH]1</smiles>

5-Fluorouracil<smiles>Nc1nc(=O)[nH]cc1F</smiles>

Flucytosine<smiles>Nc1ccn(C2OC(CO)C(O)C(F)(F)C2O)c(=O)n1</smiles>

Trifluridine
Gemcitabine<smiles>Nc1nc(F)nc2c1ncn2C1COC(O)C(COP(=O)(O)O)C1O</smiles>

Fludarabine<smiles>Cc1nc(N)c2ncn(C3OC4COC3C(O)C4O)c2n1</smiles>

Clofarabine<smiles>Nc1nc(=O)n(C2COC(CO)S2)cc1F</smiles>

Emtricitabine<smiles>Cc1cn(C2CCC(O)C(CO)C2O)c(=O)[nH]c1=O</smiles>

L-FMAU<smiles>Nc1nc(=O)n(C2CCC(CO)O2)cc1F</smiles>

Elvucitabine<smiles>Nc1ccn(C2OC3(CO)OC2C=C3F)c(=O)n1</smiles>

Tezacitabine

Figure 6.

Some important biologically useful fluorinated nucleosides \& their precursors 


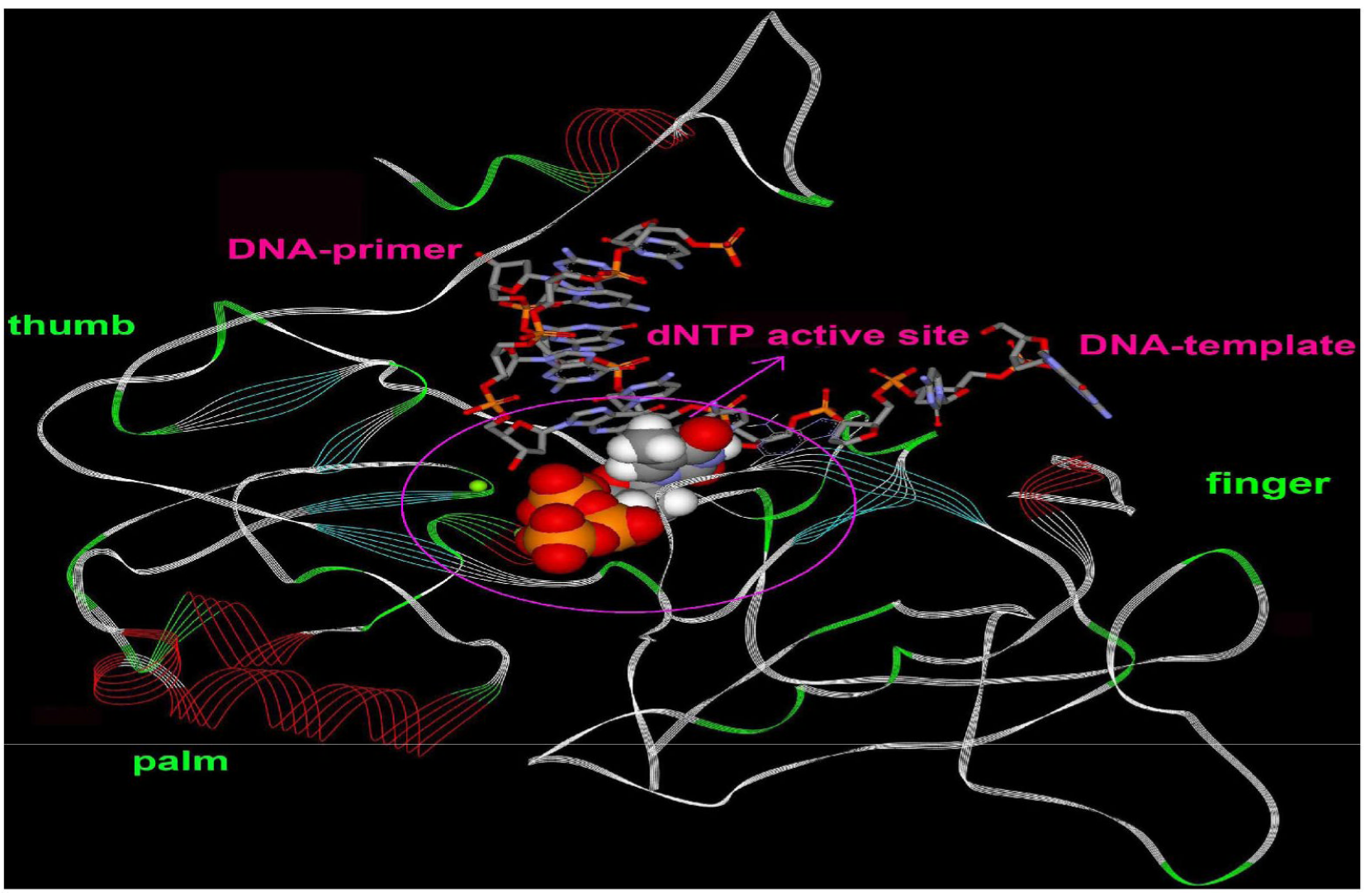

Figure 7.

A viral polymerase model structure with DNA double strand (primer and template) and natural nucleoside,highlighting the position of catalytic polymerase site. 


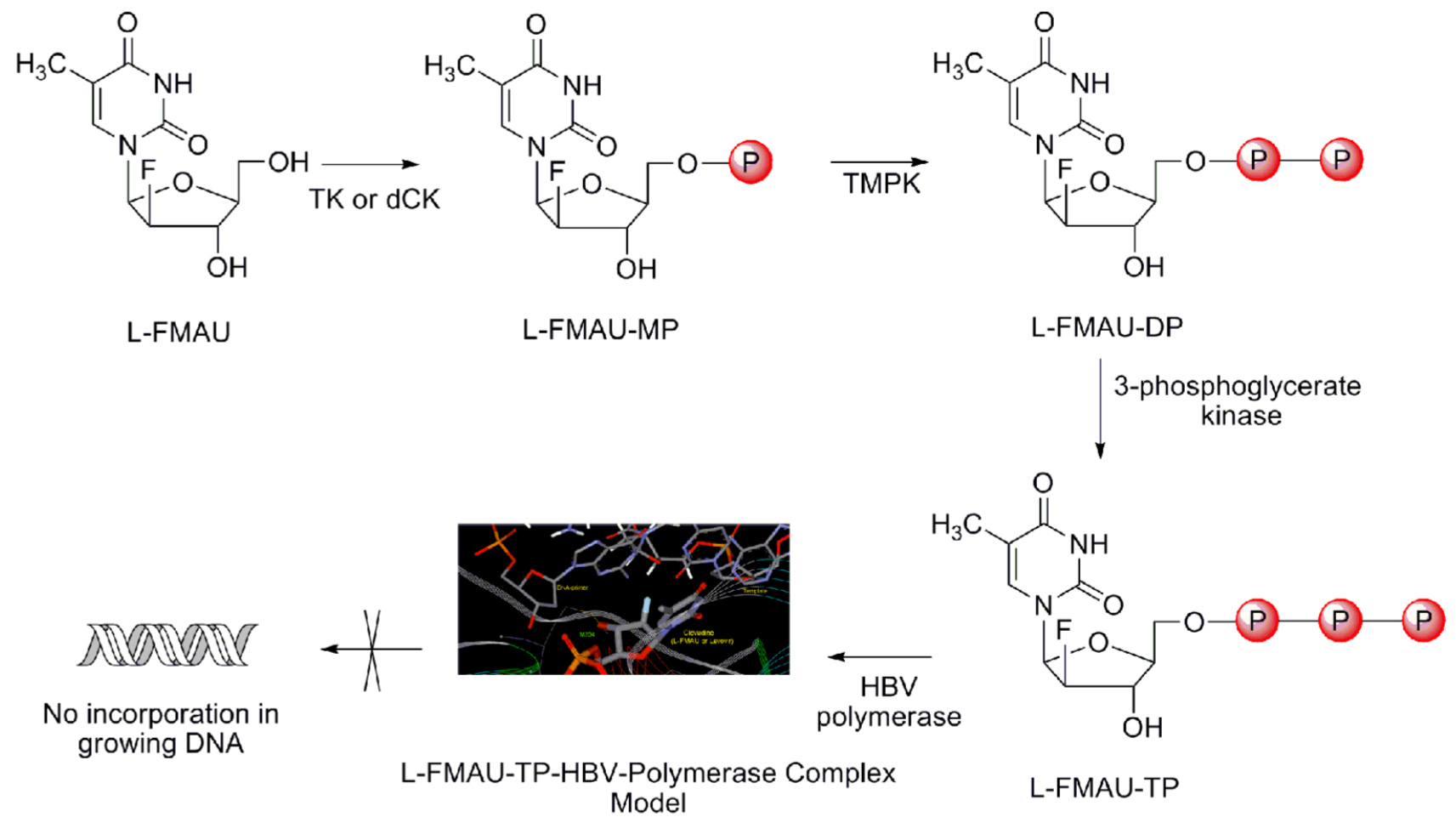

Scheme 38.

A plausible metabolic path of L-FMAU as a HBV polymerase inhibitor 


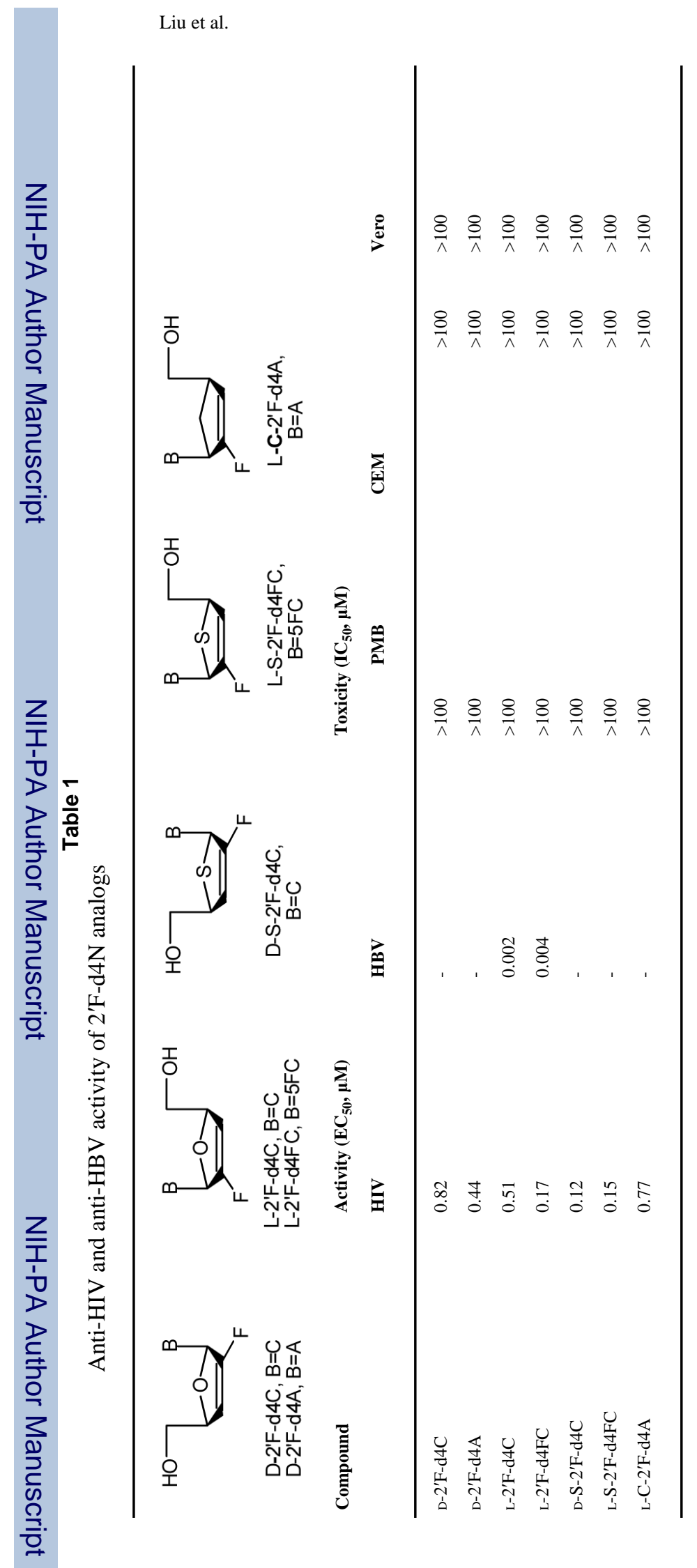

J Fluor Chem. Author manuscript; available in PMC 2009 September 1. 


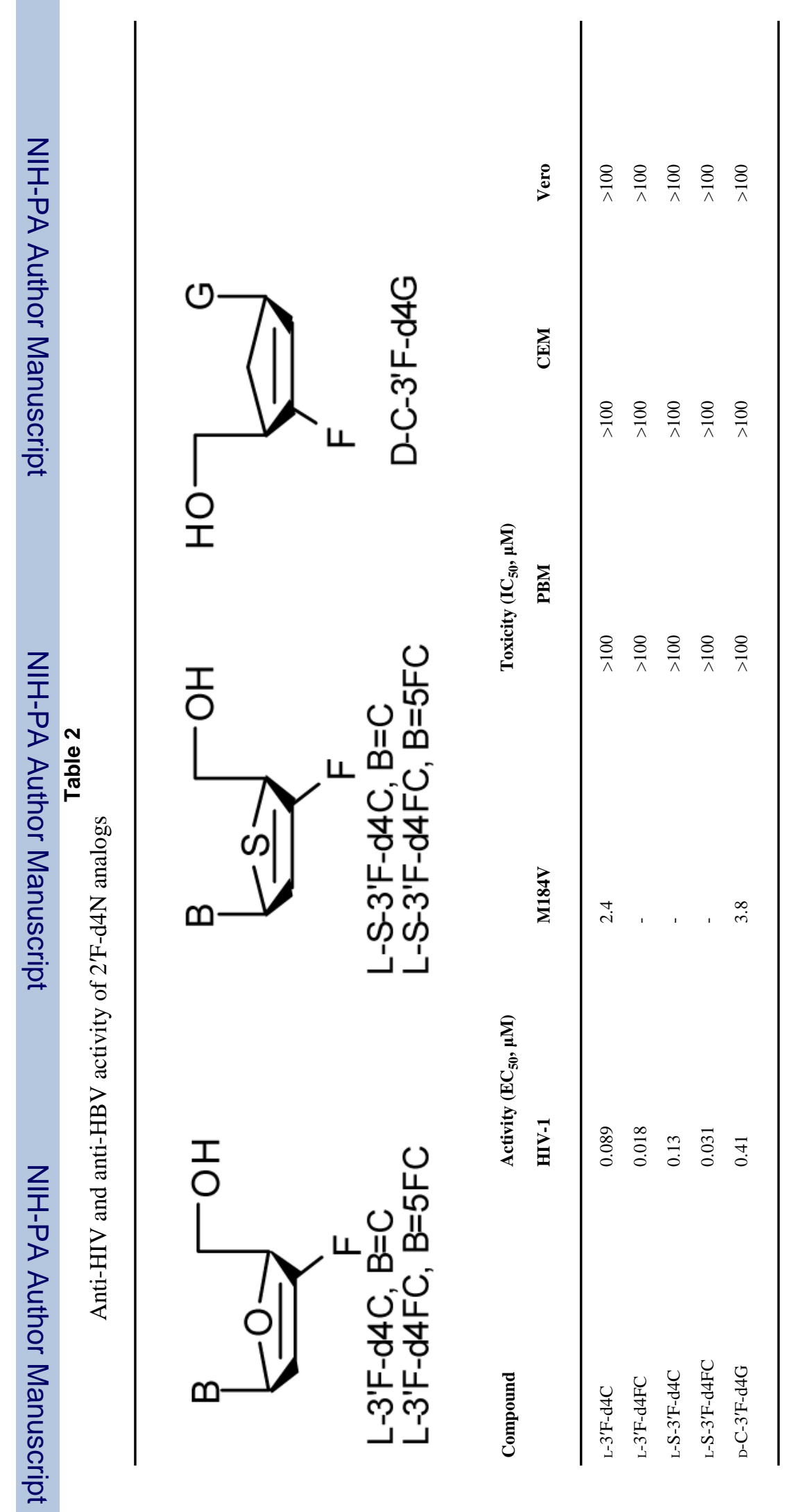

J Fluor Chem. Author manuscript; available in PMC 2009 September 1. 